NOTICE: This is the author's version of a work that was accepted for publication in Marine and Petroleum Geology. Changes resulting from the publishing process, such as peer review, editing, corrections, structural formatting, and other quality control mechanisms may not be reflected in this document. Changes may have been made to this work since it was submitted for publication. A definitive version was subsequently published in Marine and Petroleum Geology, Vol. 44, 2013. DOI:

http://dx.doi.org/10.1016/j.marpetgeo.2013.02.018 


\title{
Development of a Papua New Guinean onshore carbonate reservoir: a comparative borehole image (FMI) and petrographic evaluation
}

Moyra E.J. Wilson ${ }^{1 *}$, Dale Lewis ${ }^{2}$, O’Karo Yogi $^{3}$, David Holland ${ }^{4}$, Louise Hombo ${ }^{3,5}$, \& Adrian Goldberg $^{4,6}$

1 - Department of Applied Geology, Curtin University, GPO U1987, Perth WA 6845 Australia.E-mail: m.wilson@curtin.edu.au

2 - Schlumberger Oilfield Australia Pty. Ltd., Perth WA 6850 Australia

3 - SPI (208) Ltd., Port Moresby, Papua New Guinea

4 - InterOil Australia Pty. L-td., Cairns, QLD 4870, Australia

5 - Present address: National Petroleum Company, PNG (NPCP), PO Box 320, Port

Moresby, NCD, Papua New Guinea

6 - Present address: Eni Australia, PO Box 6862 East Perth, WA 6862 Australia

* - corresponding author

\begin{abstract}
The depositional and diagenetic controls on carbonate platform evolution are notoriously heterogeneous and difficult to determine from standard subsurface wireline logging techniques. Here, a combined borehole image (FMI - Fullbore Formation Microlmager), and petrographic study allowed evaluation of depositional and diagenetic trends across an Australasian subsurface buildup that is a major recent gas discovery. The Elk and Antelope gas fields are hosted in Tertiary reefal, platformal and associated deepwater carbonates in the present day foothills region of the Fold and Thrust Belt in the Gulf Province of Papua New Guinea.
\end{abstract}


A full suite of FMI logs (> $2800 \mathrm{~m}$ ), and 292 thin sections (mainly from sidewall cores and cuttings) from both platform flank and shallow water deposits were evaluated during this study. Despite the obvious scale differences between the datasets there was some correlation between the independent petrography and FMI studies for: a) picking major facies boundaries, and b) interpretation of depositional environments, the latter particularly for slope and deep water deposits. However, thin section petrography proved critical in understanding primary depositional textures and secondary alteration features through the shallow-water carbonates where complex diagenetic overprinting had strongly impacted original fabric, and/or in regions affected by "gas smearing". The petrographic study allowed more detailed examination of diagenesis and its impact on rock fabric (which links to the FMI textures). Component analysis and depositional textures identified in thin section are good indicators of original depositional environment. Full FMI coverage allowed textural definition on a $\mathrm{dm} / \mathrm{m}$ scale, identification and characterisation of vertical changes, and likely largescale variations in depositional environments and sequences. It was clear from combining the results of the two studies that diagenesis as well as depositional fabric had a strong impact on resultant FMI facies. The diagenetic overprinting would have been difficult to extract from the FMI data without the benefit of the petrographic work. This study shows the merits of selective petrographic analysis to calibrate the quality of facies interpretation from FMI images, and proved critical for enhancing and in places revising initial FMI interpretations.

\section{Introduction}

The depositional and diagenetic properties that control the reservoir quality of carbonate rocks are notoriously heterogeneous and difficult to predict from standard subsurface logging techniques (Nurmi et al., 1990; Akbar et al., 1995). In particular, many depositional and diagenetic facies are often not clearly defined by standard logs because of decimetre-scale averaging of many logging tools (Nurmi et al., 1990). In recent years, 
borehole imagery is being widely used to help evaluate reservoir properties and the influence that depositional and diagenetic factors have on the variability of porosity and permeability development in carbonate systems (Akbar et al., 1995; 2000/2001; Russell et al., 2002; Ahr et al., 2005). Key to the interpretation of carbonate systems, electrical borehole imaging brings the advantages that: (a) many depositional and diagenetic facies have distinctive fabrics, (b) near complete, centimetre-scale 3-D imaging is produced around the borehole, (c) fabrics relating to facies may be quantified during processing, and (d) individual identifiable rock grains or pores may be delineated and quantified through advanced processing (Akbar et al., 1995; Schlumberger, 2004). However, some have cautioned against the interpretation of borehole images in isolation from other subsurface data since this imagery: (a) only indirectly reflects porosity, fluid and mineralogical variations, (b) coalesces the combined response of depositional and diagenetic fabrics, (c) is commonly specific to wells drilled or filled with either water- or oil-based muds, (d) is sensitive to the rugosity of the borehole, and (e) may be adversely affected by factors such as gas-smearing or 'wash-out' (Nurmi et al., 1990; Akbar et al., 1995). Despite this, in uncored carbonate wells electrical images may be used as the primary interpretational tool, due to difficulties in evaluating standard wireline logs and because cuttings provide limited rock data over thick intervals. With the advent of quality rotary sidewall coring there is now the potential to calibrate and compare electrical images directly with depth-calibrated rock and petrographic data. Herein, we test to what extent a combined thin section and borehole imaging study of carbonate systems will allow enhanced definition of micro- to metre-scale variations in depositional and diagenetic character that in turn control reservoir properties. Also, it is inferred that through such a combined study it will be possible to draw meaningful interpretations about the depositional and post-depositional evolution of carbonate systems through distinguishing a wide range of carbonate deposits (from shallow to bathyal environments) affected by highly variable diagenetic alteration. 
Here, a combined detailed FMI (Fullbore Formation Microlmager) and petrographic study allowed evaluation of depositional and diagenetic trends on rock properties across an Australasian subsurface buildup that is a major recent gas discovery. The Elk and Antelope gas fields are hosted in Tertiary reefal, platformal and associated deepwater carbonates in the present day foothills region of the Fold and Thrust Belt in the Gulf Province of Papua New Guinea (PNG: Figures 1 and 2). Four wells were drilled with near complete coverage of FMI (>2800 m) and thin sections (>250 from rotary sidewall core plugs) across shallow platform to reefal buildup (Antelope-1 and -2 wells) and deeper water platform slope and bathyal deposits (Elk-1 and -2 wells). It was particularly pertinent to fully characterise the depositional and diagenetic trends and their impacts on reservoir development in the ElkAntelope system since: (a) PNG is an underexplored frontier area in which controls on reservoir development are poorly understood, (b) limited fullbore coring was conducted (Elk2 and Antelope-2), (c) seismic imaging of the carbonate system in this structurally complex region produced results that were extremely challenging to interpret, and (d) standard wireline logs did not reveal the marked heterogeneities in the system (Goldberg and Holland, 2008; Goldberg et al., 2010).

\section{Geological setting}

The Elk and Antelope gas fields are hosted in Tertiary reefal, platformal and associated deep water carbonates. The fields lie at the leading edge of the New Guinea Orogen (NGO) as defined by Pigram \& Davies (1987), Struckmeyer et al. (1993) and Davies et al. (1996). The NGO is the collisional zone between the relatively stable Australian cratonic area in the southwest and the islands and ranges constructed by Cenozoic volcanic activity in the northeast. The Elk/Antelope fields are located at the junction of the two dominant fold belt trends with the Papuan Fold Belt to the west and the Aure Tectonic Belt to the east (Figure 1). 
Extensive 2-D seismic coverage in combination with airborne gravity and magnetic surveys over the fields established the structures on which five wells were drilled. Currently, two wells have been drilled in the Elk Field (Elk-1 and Elk-2) and three in the Antelope Field (Figure 2; Elk-4, Antelope-1 and Antelope-2). Carbonates in the Elk Field consist of deepwater platform slope and bathyal deposits. Carbonate facies in the Elk-4 well are similar to those from the Elk Field. In comparison, the Antelope wells penetrate shallow platform to reefal-buildup deposits. The slope deposits encountered in the Elk wells originally flanked the contemporaneous shallow-water carbonate development of the Antelope wells. Postdeposition, carbonates in the Elk Field have been structurally separated, and displaced upsection, from those in the Antelope Field by a WSW-ENE trending, SSE verging thrust (Figure 2). The combined Elk/Antelope fields have approximate dimensions of 15 kilometres ( 9 miles; $\mathrm{N}$ to $\mathrm{S}$ ) long by 5 kilometres ( 3 miles; $\mathrm{E}$ to $\mathrm{W}$ ) wide with a gas column of $>600 \mathrm{~m}$ $(>2,000 \mathrm{ft})$ in the carbonate section (Harris et al., 2009). Carbonates penetrated by the wells are the Eocene to Lower Oligocene Mendi (Limestone) Group, Oligo-Miocene Darai Group equivalent (neritic with some reworking) and the Upper Oligocene to Miocene Puri Limestone Formation (bathyal to outer neritic: Pigram et al., 1989; Goldberg and Holland, 2008). The thickness of shallow-water carbonates is at least $960 \mathrm{~m}$ (encountered in Antelope-1: the well with maximal stratal penetration).

The carbonates are overlain by a thick, clay-rich mudstone (Orubadi Formation (or Orubadi Beds); cf. Pigram et al., 1989; Goldberg and Holland, 2008) containing abundant planktonic foraminifera of latest Miocene to earliest Pliocene age. The known thickness of the Orubadi Formation in the vicinity of the fields varies from 1000 to around $2000 \mathrm{~m}$, although there has been significant post-depositional erosion associated with fold and thrust belt development (Goldberg and Holland, 2008). In the Elk field, there is a gradational down-sequence change from mudstones of the Orubadi Formation to marls and then carbonate. In the Antelope field, no marl is present and the Orubadi Beds directly overlie the 
carbonate. All wells were terminated in the carbonate section; and the lithology below the reservoir is therefore unknown.

\section{Methodology}

A full suite of FMl logs $(2873 \mathrm{~m})$ and 292 thin sections from shallow water, platform flank and basinal deposits of the Elk - Antelope system were evaluated. Limited fullbore core was also available from Elk-2 (Core 1: 2658-2661.16 m, Core 2: 2708.66-2710.0 m) and Antelope-2 (Core 1: 1835.06-1840.49 m, Core 2: 1846.09-1881.85 m, Core 3: 2184.02193.27 m, Core 4: 2337.9-2351.84 m). Petrographic and FMl analyses were undertaken independently since the FMI images were available before the thin sections, with the results then compared and integrated. FMI intervals studied and numbers of thin sections (TS) for each of the wells are: (a) Elk-1 - 1630-1840 m (210 m in total) \& 7 TS, (b) Elk-2 - 2204$3325 \mathrm{~m}$ (1121 m in total) \& 32 TS, (c) Antelope-1 - 1731-2455 m (724 m in total) \& 130 TS, and (d) Antelope-2 - 1812-2450 m (818 m in 4 runs) \& 123 TS. Additional geochemical and microscopy data from the Elk-Antelope system utilised in the full diagenetic interpretation will be published elsewhere.

Borehole image logs supply geoscientists with high-resolution records of rock properties and characteristics along the borehole wall (Lagraba et al., 2010). They provide a computer generated image based on geophysical measurements of acoustic reflectivity or of electrical conductivity, and represent formation response at the borehole wall, giving a continuous vertical record of the borehole circumference (Rider, 2002). Wireline-based resistivity imaging tools are configured with various arms each of which consists of a pad (and possibly an associated flap) that contains sensors which when pressed against the borehole wall record electrical current that was emitted from the sensors of the tool into the formation (Lagraba et al., 2010). Schlumberger's Fullbore Formation Microlmager (FMI) is a wireline-based microresistivity formation imager used in water-based muds, which uses 192 microresistivity buttons spaced along four pads and flaps to generate a high (0.2 inch) 
resolution borehole image with an $80 \%$ borehole coverage in 8 inch wells (Schlumberger, 2004). During processing, borehole images are subjected to various stages of a processing workflow, the most important of which are speed correction and image orientation using high-resolution accelerometer and magnetometer data, the mapping of a colour scale to resistivity values, and the use of filtering/enhancements to remove non-geological artifacts. Image quality can be affected by the presence of artifacts related to logging activities (e.g., stick-slip effects), borehole wall conditions (e.g., rugosity, washout, breakouts), processing (e.g., pad mismatching) or the geological formation (e.g., halo effects around pyrite nodules; García-Carballido et al., 2010). Borehole images are typically presented in "unwrapped borehole" format with the cylindrical borehole surface log unzipped at the north azimuth and unrolled to a flat strip, on which straight dipping surfaces are represented by sinusoids (Rider, 2002).

The interpretation of borehole image logs provides directional sedimentological and structural information which can provide high-resolution data to integrate into reservoir and geomechanical models (García-Carballido et al., 2010). The sedimentary interpretation of electrical image logs tends to follow routines similar to those used in a purely sedimentological analysis, building up through lithology, texture, and sedimentary structures to facies and eventually sequences (Rider, 2002). It should, however, be recognised that any information from downhole images reflects the combined electrical response of downhole variations in mineralogy, textures, pore systems and fluids. In addition to their use in sedimentary interpretation, image logs have been used for various quantitative analyses in carbonate reservoir characterisation, particularly in porosity and permeability analysis of vuggy carbonate reservoirs (Nurmi et al., 1990; Chitale et al., 2010; Xu, 2010). With many productive carbonates having dual porosity systems, Newberry et al. (1996) developed a technique for transforming electrical images into porosity maps of the borehole, allowing partitioning into primary (matrix) and secondary (vuggy) porosity. Russell et al. (2002) developed a methodology using electrical image logs and conventional log data to 
characterise and extrapolate geological heterogeneity that provided permeability prediction (via vug connectivity) when applied to the Shuaiba reservoir of Oman.

Following acquisition and loading, the FMI data used in this study underwent environmental quality control and correction (including depth correction). Processing and interpretation of the FMI image data was completed by D. Lewis at Schlumberger; initially in an automated (default settings) way and with further refinement to improve image quality. Image enhancement prior to graphical display was through optimisation of the usage of colours via two methods: (a) static normalisation that is a global optimisation, and (b) dynamic normalisation that is a local optimisation using a sliding window. Borehole wall conditions were also assessed as to how they may have affected FMl image quality. Although borehole washouts were common in the Elk and Antelope wells, only in Antelope-2 does this appear to have significantly affected image quality, though pad contact remained good. In the upper parts of the Antelope wells gas smearing had adversely affected the quality of the image logs, a problem for which there is no correction. This is caused by gas in the borehole obscuring the formation by increasing resistivity between the pads and the borehole wall.

On the FMI images geological features such as bed boundaries, unconformities, fractures and potential sedimentary structures were identified and where appropriate their dips evaluated. FMI facies were defined using: the visual appearance of the image, BorTexcalculated textural outputs, and associated FEQL-calculated petrophysical outputs. BorTex is a Geoframe borehole image texture analysis application that was used in this study to calculate: (a) the overall conductivity ("Background Conductivity") of the image, (b) bedding density ("Lamination Density") using vertical changes in conductivity, (c) heterogeneity of resistive and conductive spots/patches ("Resistive versus Conductive inclusions"), and (d) connectiveness of conductive spots/patches ("Connectivity Index Coefficient") that provide an indication of permeability. FEQL (Formation Evaluation Quick Look) is a Schlumberger 
petrophysical process, which provided lithology, porosity and clay content information used to help define the FMI facies. FEQL does not use image data and was undertaken "in-house" at Schlumberger utilizing the petrophysical data obtained via wireline logging, either in tools run in the same tool string as the FMI, or in other runs (usually the first tool run collects the main petrophysical data). Gamma Ray, Resistivity, Density, Porosity, Sonic, PEF (Photoelectric Factor) data were combined from a number of different runs and correlated in depth for each well. Although FEQL is produced independently of the FMI image interpretation, "outputs" that include lithology, porosity, fluid- and clay-content data are often used as "inputs" for the FMI image interpretation.

For the FMI facies nomenclature, textural terms are subjective and based only on visual FMI image appearance. Fine-grained FMI textures refer to smooth image appearance in which grains are below image resolution pixel size $(<1.5 \mathrm{~cm})$; whereas, coarse-grained textures refer to granular image appearance with resolvable grains $(>1.5 \mathrm{~cm})$. "Conglomerate" refers to images in which individual "clasts" are visible with no internal order; whereas, "boundstone" refers to such conglomerate in which an internal fabric is also visible. Laminated or thinly-bedded facies have a "Lamination Density" of $>10 / \mathrm{m}$; whereas, for medium- to thickly-bedded facies it is $<10 / \mathrm{m}$. Since the borehole images are a combined response to mineralogy, porosity, fluid and textural variations, FMl facies were subdivided to best capture lithological, textural and petrophysical properties (although variations in reservoir quality are not addressed here). Following identification of individual FMI facies the logging sequence was divided into a number of composite facies or zonations based on a common assemblage or dominance of certain FMl facies.

Petrography of 292 thin sections, mainly from sidewall cores and cuttings, allowed determination of carbonate components, microfacies, environmental interpretations and diagenetic evaluations (Appendix 1). Samples were stained with Alizarin Red $S$ and potassium ferricyanide to allow differentiation of ferroan and non-ferroan calcite, as well as dolomite (Dickson, 1965; 1966). Facies nomenclature follows the textural classification 
scheme of Dunham (1962), modified by Embry and Klovan (1971), with components given in lithology names where they exceed 10-15\%. Nomenclature on carbonate cement geometries follows Flügel (2004). Age dating of samples was undertaken via foraminiferal biostratigraphy and strontium isotope analysis, although these results are not discussed in detail here (Haig, pers. comm., 2010; Allan, pers. comm., 2011; following van der Vlerk and Umbgrove, 1927; Blow, 1969; 1979; Adams, 1970; McArthur et al., 2001; Lunt and Allan, 2004; McArthur and Howarth, 2004). Initial interpretations of the FMI and petrology were compared, and the results of both datasets combined to provide an overall depositional and diagenetic evaluation.

\section{Elk-1 and 2 wells: FMI facies and their downhole distribution}

A similar suite of FMl facies were defined for the Elk-1 and 2 wells, for which all dating of samples yielded Miocene ages (Figures 3 and 4). Four FMI facies were common to both wells, with an additional two and three defined in just the Elk-1 and Elk-2 wells, respectively (see Table 1 for FMI-facies characteristics). Out of the FMl facies, marls are common at the top of the Elk-1 and -2 wells (Figure 3 and 4) and were defined as a limestone with $>35 \%$ clay content (from FEQL) that has high overall conductivity (Figure $5 b)^{1}$. Overall the texture of the marls on the FMI images appears smoother than other facies, but subequal amounts of thin to medium conductive and resistive beds and faint

\footnotetext{
${ }^{1}$ In the Elk and Antelope wells the Gamma Ray response is not always a reflection of clay content, since locally the carbonates are "hot" (see directly below). In the Elk-1 well the Accelerator Porosity Sonde (APS - neutron porosity tool) Formation Capture Cross-Section (SIGF) results for clays is high and for carbonates and gas is low. Therefore the SIGF results, through FEQL processing, provided the data for clay volumes (Vclay), i.e. the output for the lithology column in Figure 3. Partly because of this anomalous Gamma Ray response the Photoelectric factor tool (PEF) was run in wells subsequent to Elk-1. PEF revealed that some of the high gamma response zones contain dolomite, and this was fully corroborated through thin section petrography (see Antelope wells results and interpretation). Spectral gamma response, from tools run in Elk-2 and the Antelope wells, revealed that dolomitised intervals are locally Uranium-rich (causing the "hot" response). Although not shown in the lithology column for the Elk-1 well (Figure 3), the high gamma response in the interval 1810$1819 \mathrm{~m}$ may correspond to dolomite content. Dolomite content as identified during FEQL processing is shown in the lithology columns for Elk-2, Antelope-1 and -2 wells in which the PEF tool was run (Figures 4, 8 and 9).
} 
lamination were observed. Below, and interbedded with, the marls in the upper parts of the imaged Elk-1 and -2 successions argillaceous laminated thinly bedded limestone, and in the case of Elk-1 nodular and argillaceous limestones, predominate to depths of 1709 and 2671 $\mathrm{m}$, respectively (Figures 3 and 4). The argillaceous laminated-thinly bedded limestone consists of laminated to thinly interbedded limestone, characterised by a lamination density usually $>10$ lamina/m, and a clay content $>10 \%$ (from FEQL), with moderate conductivity (Figure $5 d$ ). Subequal amounts of thin resistive beds and conductive laminations or thin beds have clearer definition than in the marls, but are less well-defined than in the laminated-thinly bedded limestone (see paragraph below). The nodular and argillaceous limestone FMI facies is similar to the argillaceous facies described directly above, although clay content may drop below $10 \%$ and resistive beds with a nodular, irregular to wavy texture commonly outweigh conductive ones (Figure 6c).

Laminated-thinly bedded limestone FMI facies dominate in the middle part of the imaged section of both wells (1709-1792 m in Elk-1 and 2671-2925 m in Elk-2; Figures 3 and 4). This facies consists of thin resistive beds of limestone interbedded with very thin conductive laminations; overall conductivity is low and lamination density high $(>10$ lamina/m; Figure $6 \mathrm{a})$. A clay content of $<10 \%$ has been used to artificially set the boundary between the laminated and argillaceous laminated-thinly bedded limestone and there is some interdigitation of the two facies in the upper part of Elk-2 (Figure 4). In the lower middle portion of Elk-1 minor units of the argillaceous and nodular facies, as well as a mottled bioturbated limestone are also present (Figure 3). The mottled/bioturbated limestone was only seen in Elk-1 and has a distinctive appearance consisting of thick to massive resistive limestone beds with a crushed 'meshwork' fabric (Figure 6g). Within the middle portion of Elk-2 beds of fine-medium or coarse limestone conglomerate/breccia and medium-thickly bedded limestone are also present (Figure 4). The fine-medium limestone conglomerate/breccia consists of 'medium-sized', well-defined resistive clasts that contrast markedly with a conductive matrix (Figure 7a). Clasts vary from granule to pebble grade, but 
are mostly in the pebble grade, and vary from angular to rounded. Matrix-dominated textures predominate and layering via clast alignment may be visible.

The basal part of the imaged section of Elk-1 (1792-1822 m) consists of mediumthickly bedded limestone (Figure 3). This medium bedded FMl facies consists of medium to thick resistive limestone beds with fine conductive interlaminations, and a lamination density usually $<10$ lamina/m (although fracturing may artificially enhance lamination density; Figure 6e). This medium bedded facies is also present as minor interbeds in the middle portion of Elk-1 and the middle to lower imaged part of Elk-2 (Figures 3 and 4). The basal portion of Elk-2 consists predominantly of a coarse limestone conglomerate/breccia (2925-3241 m) and in its lowermost part a strongly dolomitised/altered limestone (3241-3310 m; Figure 4). The coarse conglomerate/breccia is similar to the fine-medium limestone conglomerate/breccia described above except that clasts vary from granule to cobble grade, but are mostly in the upper pebble to cobble grade, with some having blurred margins (Figure 7e). Matrix-supported textures are most common, although the ratio of clasts to matrix varies considerably and clast-supported textures are also locally seen. Minor interbeds of the coarse limestone conglomerate/breccia are also present in the middle imaged part of Elk-2. Units of the fine-medium limestone conglomerate/breccia, laminated and medium-thickly bedded limestone interbed with the coarse limestone conglomerate/breccia in the upper basal part of Elk-2 (Figure 4). The strongly dolomitised/altered limestone conglomerate/breccia is very similar to the coarse limestone conglomerate/breccia FMI facies described directly above except that the boundaries between clasts and matrix are blurred, and dolomite is usually indicated on FEQL (Figure $7 h)$.

\section{Elk-1 and 2 wells: Initial interpretation from FMI data}

On the basis of their clay content, generally smooth appearance (and inferred fine grained nature) together with plane parallel lamination the marl, argillaceous and laminated- 
thinly bedded limestone FMI facies are all interpreted as low energy deposits. Considering the regional context a deep water marine origin was likely for all these deposits, with the marl having the 'smoothest' texture and highest clay content being the deepest water deposit in the succession. Nodular limestones are also found in deep water settings, where the irregular fabric, if of primary depositional origin, commonly results from soft sediment deformation of coarser layers upon softer, finer-grained ones. The more resistive laminae noticeable in the argillaceous, nodular and particularly the laminated facies may represent layers of fine-grained limestone material that has been winnowed in, or transported into, the low-energy, deep-water setting. The medium-thickly bedded limestone was interpreted to represent fine to medium grained limestone, most likely deposited in shallower water depths than the laminated facies. The origin of the minor mottled/bioturbated facies is unclear. It is probable, however, that this facies represents medium-thickly bedded limestone that has been highly fractured, but which may have been altered to some extent, possibly by bioturbation or some other process.

The clasts within the fine-medium and coarse limestone conglomerate/breccia are both interpreted to be bioclasts or perhaps limestone clasts of variable size within a generally finer grained matrix. Where the conglomerate/breccias interbed with facies of inferred deep water origin, derivation of shallow bioclasts or limestone from an adjacent carbonate edifice, emplaced during storms or via sediment gravity flows is likely. Some of the conglomerate/breccia beds show upwards fining (of conductive patches/spots) and lamination towards the top of units consistent with structures common in calciturbidites (Figures $7 \mathrm{a}$ and $\mathrm{c}$ ). Although the down-hole appearance of the conglomerate/breccia units may reflect increasing proximity to a carbonate platform margin where these facies predominate, particularly in the lower parts of the wells, and especially in Elk-2, shallowing of the depositional environment seems likely (Figure 4). The coarse limestone/breccias typically have less internal structure than the finer units and emplacement via debris flows or as downslope talus deposits seems likely. Although an interpretation of near in-place 
shallow water deposits was a possibility for the lower part of Elk-2 a platform slope origin was preferred since none of the material was in-situ and because units of the same FMl facies interdigitate with the deeper water deposits in the middle portion of the well. The strongly dolomitised/altered limestone conglomerate/breccia facies probably has similar, or perhaps shallower-water origins to the coarse limestone breccia/conglomerate. The blurred boundaries between clasts and matrix in this facies, and to a lesser extent the coarse conglomerate/breccia, together with an indication of dolomite on FEQL, are probably due to dolomitisation, or some other alteration along clast margins, as pad contact is generally good.

The logging sequences were divided into a number of zones based upon a common assemblage or dominance of certain facies (Table 2). These zones give an indication of changes in depositional environment. On the basis of up-hole changes an overall transition from a lower-upper rimmed carbonate slope at the base of the imaged succession to a lower slope or basin floor environment at the top is inferred for both Elk-1 and -2 (Figure 3 and 4). The interval of dolomitised/altered and coarse limestone conglomerate/breccia at the base of Elk-2 is likely to be proximal gravity driven mass transport units from a nearby platform margin and an upper slope environment is inferred (Figure 4). Laminated-thinly bedded and medium-thickly bedded facies with limestone conglomerate/breccia interbeds are inferred to accumulate under low to moderate energy background conditions on the lower to upper slope (intermediate) with conglomerate/breccias emplaced during storms or gravity flow episodes. Zones of almost exclusively laminated-thinly bedded limestone are likely to be low energy deposits accumulated out of the range of proximal gravity-driven flow events, but perhaps still receiving distal flows on the lower slope. Interbedded clay-rich and none clayrich facies including laminated-thinly bedded limestone are inferred to have accumulated under lower energy conditions of the deeper part of the lower slope. The zones of marls interbedded with argillaceous limestone are very low energy deposits attributed to deeper water conditions than the deep lower slope, moving out onto the basin floor environment. 
On the basis of these changes within the overall deepening upward trend in each well, three and four potential large-scale deepening upwards sequences were identified in Elk-1 and -2, respectively (Figures 3 and 4).

\section{Elk-1 and 2 wells: Petrology, comparison with FMI data and overall interpretation}

A limited number of cutting samples (7) were available from Elk-1 between 1671 and $1692 \mathrm{~m}$ that span FMI facies of nodular and argillaceous laminated-thinly bedded limestone (Appendix 1). Good coverage of samples (28) predominantly from sidewall cores and core plugs were available from Elk-2 spanning the whole imaged section and covering all FMl facies. The only area of poor sample quality in Elk-2 was from the lower part of the well below 2969 m where drilling issues were encountered and the only 3 samples available are cuttings, that may be cavings. Age dating of these lower cutting samples from $\mathrm{Sr}$ isotope analysis in Elk-2 yielded anomalous results that appear younger than in the overlying samples, and for these reasons the cuttings attributed to the dolomitised/altered limestone conglomerate/breccia zone could not be confidently linked to this FMI facies. Overall, meaningful comparison was therefore possible for all FMI facies in Elk-1 and -2 with the exception of the minor mottled/bioturbated and dolomitised/altered facies. Depositional interpretations from original FMI analysis were generally corroborated following petrography. Due to better sample coverage most data is drawn from Elk-2 but the findings also hold for Elk-1, particularly in its upper section.

On the basis of petrology the marl, argillaceous and laminated FMI facies with high clay-size content (generally $>50 \%$ ) and abundant well-preserved planktonic foraminifera are low energy, deep marine deposits. The marl FMI facies corresponds to a planktonic foraminifera wacke/mudstone or marl. With the highest clay-sized content $(>90 \%)$, mud/wackestone textures and planktonic foraminifera comprising $>80-90 \%$ of allochems the marls accumulated in bathyal water depths and are the deepest water deposits (Figure 5). Three samples corresponding to argillaceous laminated-thinly bedded facies in Elk-2 and all 
the samples in Elk-1 are (or in the case of the cuttings, include) planktonic foraminifera wacke/packstones (Figure 5e-g). These wacke/packstones contain less clay-sized matrix $(60-80 \%)$ than the wacke/mudstone or marl, but again are dominated by generally wellpreserved and usually whole, though sometimes crushed planktonic foraminifera. Bioturbation is common, with now compacted, mostly bed parallel burrows of a few millimetres in diameter infilled mainly with clay-sized matrix (Figure 5f). Slightly irregular, layer parallel anastomosing dissolution seams, some developed preferentially along burrows, along and around which insoluble matrix is concentrated are another common feature in the wacke/packstone that are not evident in the wacke/mudstone (Figure 5f). Within some of the planktonic foraminifera-rich wacke/packstones disseminated, or interbedded laminae richer in, shallow fragmented bioclasts are present (including larger benthic foraminifera and minor corals). At Elk-2 $2659.5 \mathrm{~m}$ one of these lamina rich in shallow bioclasts is partly silicicified (Figure $5 \mathrm{~g}$ ). The laminated-thinly bedded limestone FMI facies corresponds to planktonic foraminifera packstones interbedded with planktonic foraminifera bioclastic packstones, containing up to $10 \%$ and $40 \%$ fragmented shallow water bioclasts, respectively (Figure 6b). This laminated facies includes some bioturbation, compaction and alignment of bioclasts parallel to bedding, and dissolution seams particularly developed along lithological boundaries. Successive changes from the marls to wacke/packstone and then packstone textures of the argillaceous and laminated FMI facies respectively, and the associated reduced clay-sized and planktonic foraminifera content are consistent with a shallowing, or more winnowed trend, but still within a deep marine context (Figure 6). Bioturbation in these three facies are indicative of oxic conditions at the sea bed. Petrology reveals that the laminations seen in a number of the FMI facies are likely to have multiple origins including: (a) bed parallel bioturbation, (b) development of dissolution seams and perhaps other compaction related features, (c) interlamination of units richer in reworked shallow bioclasts, and (d) layer parallel silicicification. The cutting sample in the nodular and argillaceous limestone zone in Elk-1 is the sample with the most coral material (Figure 6d) and it is probable that some of the nodular appearance may be due to compaction around 
coral clasts. The presence of fragmented shallow-water bioclasts including larger benthic foraminifera and corals in the laminated and nodular facies indicate reworking from a nearby shallow platform into deeper water. In addition to dissolution seams, mechanical compaction, and rare partial silicicification, equant cements and sutured grain contacts are other diagenetic features present in all of the planktonic foraminifera-rich facies.

Abundant fragmented shallow water material together with lithified carbonate clasts of both shallow and deep water origin and well-preserved planktonic foraminifera in the two conglomerate/breccia facies are consistent with downslope shedding of platform top and slope material into deeper water (Figure 7). The fine-medium limestone conglomerate/breccia FMI facies were sampled 10 times in Elk-2 (Appendix 1). At 2709 and $2779 \mathrm{~m}$ the upper two fine-medium conglomerate/breccias that were sampled correspond to planktonic and larger benthic foraminifera bioclastic packstones. These packstones contain well preserved planktonic foraminifera, together with slightly fragmented, but commonly well preserved flattened or robust larger benthic foraminifera, echinoderm, coralline algae and bryozoa debris with very minor amounts of lithoclasts of planktonic foraminifera wackestones. Most other sampled sites, however, are coral, larger benthic foraminifera and carbonate lithoclastic pack/rudstone/breccias (Figures $7 \mathrm{~b}$ and $\mathrm{d}$ ). These rudstone/breccias include a range of fragmented or abraded shallow water bioclasts, including pebble-sized reworked coral material, well preserved planktonic foraminifera together with limestone clasts of bioclastic packstone (Figure 7d). The lower two fine-medium conglomerate/breccias sampled at 2925 and $2926 \mathrm{~m}$ correspond to dolomitised foraminifera and echinoderm bioclastic packstones, containing abundant fragmented benthic foraminifera and echinoderm debris, but only very rare planktonic foraminifera. One sample of the coarse limestone conglomerate/breccia FMI facies is an altered planktonic foraminifera pack/floatstone with pebble-sized coral fragments (Figure 7f). The other samples of this FMI facies are probably dolomitised breccias (Figure 7g). On the basis of the petrology it therefore appears that the conglomerate/breccia FMI facies represent a range of microfacies including bioclastic 
packstones, coral floatstone, rudstones and breccias with clasts or bioclasts of variable sizes. In both conglomerate/breccia facies dolomitisation post-dates reworking of clasts, compaction, and some fracturing. Other diagenetic features present in both facies include syntaxial overgrowth cements on echinoderm debris, mechanical compaction, granular mosaic, blocky and equant cements. Cements such as the granular mosaic ones replacing corals have occurred prior to bioclast reworking, whereas most equant cement formation post-dates reworking.

The medium-thickly bedded limestone FMl facies was only sampled twice in Elk-2. In the upper part of the well one sample is a planktonic foraminifera bioclastic packstone including fragmented larger benthic foraminifera, coralline algae and well preserved planktonic foraminifera (Figure 6f). The sample at $2968 \mathrm{~m}$ falls within the medium-thickly bedded FMI facies, but is very close to a medium limestone conglomerate/breccia and it is difficult to tell which facies is represented. Sample $2968 \mathrm{~m}$ is a very heavily dolomitised carbonate lithoclastic \& bioclastic pack/rudstone/breccia including fragmented larger foraminifera as well as clasts of bioclastic packstone and grainstone.

Overall, the comparative petrology and FMI data study yielded a consistent interpretation of depositional environments and sequence trends for Elk-1 and Elk-2. The apparent increase in abundance of planktonic foraminifera and decrease in shallow bioclastic material uphole is consistent with a deepening trend or increasing distance from a platform margin. On the basis of the petrology and FMI interpretations both Elk wells are interpreted to pass through slope and basinal facies with a general up sequence deepening trend (Figures 3 and 4). The interpretation of three to four smaller-scale deepening upwards sequences within each well also holds following the petrographic analysis (Figures 3 and 4), although greater sampling frequency would have allowed further evaluation of the smallerscale trends inferred from FMI. A rimmed shelf margin setting to a partially erosional margin is inferred due to the amount of coarse coral debris, and lithified carbonate material reworked into deeper planktonic foraminifera-rich deposits. There has been some reworking 
of a range of shallow-water clasts together with deeper-water planktonic foraminifera-rich packstones and wackestones. The data from petrology therefore provides enhanced knowledge on the nature of the platform margin indicating that erosion of previously lithified carbonate material was an additional feature of the rimmed margin initially inferred from FMI.

In general for both Elk wells, FMl facies strongly reflect original depositional fabrics with relatively minor diagenetic overprint. Exceptions are the mottled/bioturbated facies that is interpreted to be diagenetic (fracture/alteration). Also some of the laminations seen on FMI likely reflect compactional features in which insoluble material is concentrated along dissolution seams, and/or a compactional overprint of earlier primary depositional lamination. The majority of other diagenetic features in the Elk wells are also interpreted to be burial related, but have had little impact on FMI images. The dolomites that are locally important towards the base of the wells, post-date many of the compactional features and are also attributed a burial origin. The dolomites appear to have precipitated along more permeable zones, including along clast boundaries, in fractures, or within more permeable sediments. The presence of dolomites has resulted in some 'blurring' (of clast boundaries) and perhaps some of the more conductive 'patches' on the FMl images.

\section{Antelope-1 and 2 wells: FMI facies and their downhole distribution}

A similar suite of FMI facies were defined for the top and middle imaged part of Antelope-1 as for the middle and lower imaged sections in Antelope-2. FMl analysis was initially run prior to independent age dating or petrography. Extensive dolomitisation in the upper and middle imaged portions of Antelope-1 and -2, respectively, was evident from the FEQL plots (mainly through the PEF results). It was recognised from the outset that textures seen in the FMI images due predominantly to this dolomitisation, or other diagenetic overprints, were difficult to distinguish from what may have been primary depositional features. There was a tendency to attribute textures to potential depositional origins, unless 
a later alteration texture (such as fracturing) was clear. Poor image quality in Antelope-2 (1938-2088 m and below $2123 \mathrm{~m}$ of the main pass and in the entire 6.125 "' section between 2224 and $2450 \mathrm{~m}$ ) and Antelope-1 (locally in the upper half of the imaged section), mainly due to uncorrectable gas smearing (Figure 11a) compounded the issue of data interpretation and facies correlation between the wells. Fortunately, in a repeat pass of Antelope-2 below $2100 \mathrm{~m}$, the image log was not affected by gas smearing, allowing interpretation down to $2218 \mathrm{~m}$ (in the 8.5 " section). As discussed below thin section petrography subsequent to the FMI analysis proved critical in understanding primary depositional textures and secondary alteration features in the Antelope wells. Five FMI facies were common to both Antelope wells, with an additional four and two facies defined in just the Antelope- 1 and -2 wells, respectively (see Table 3 for FMl-facies characteristics).

The upper part of Antelope-2 (1829-1939 m) consists of a vuggy mottled limestone conglomerate/boundstone FMI facies that was not present elsewhere in the well or in Antelope-1. This vuggy mottled facies has a generally distinct resistive or slightly conductive limestone fabric with common conductive vugs and holes, and a conductive mesh-like 'layering' (Figure 10a-c). The facies is massive to thickly bedded. 'Clasts' are visible, but these 'blur' into the overall fine to more medium grained fabric seen on the images and sometimes form an internal structure suggestive of boundstone.

The upper part of Antelope-1 (1732-1935 m) and middle section of Antelope-2 (1939-2211 m) consist almost exclusively of low-, moderate-, and high-conductivity vuggy dolomite conglomerate/boundstone FMI facies (Figure 11). High to moderate conductivity dolomites predominate in Antelope-1, whereas low to moderate conductivity dolomites predominate in Antelope-2. These dolomitised facies commonly have a slightly blurred appearance on the FMI images and are massive to thickly bedded, with bedding generally highly discrete yet visible as very thin conductive layers. The variably resistive to conductive dolomite facies contain variably abundant vugs and larger holes (Figure 11a-d). Clasts are sometimes visible, but may blur into the overall fabric on the image and form an internal 
structure suggestive of boundstone. The background dolomite appears fine to medium grained. The highly conductive dolomite intervals in both Antelope-1 and -2 have significantly greater gamma readings than the other facies in these two wells (see footnote 1). Unlike the other two dolomite facies a limestone component is almost completely absent from the highly conductive dolomite in Antelope-2, and comprises $<10 \%$ in all the dolomite FMI facies in Antelope-1. The dolomite content of the moderate- and low conductivity dolomites in Antelope- 2 is $>80 \%$ and $>60 \%$, respectively.

In the lower predominantly dolomitised middle section of Antelope-2 (2143.5-2211 m) there are gradational changes (defined from $F E Q L$ ) from low-conductivity dolomite to three interspersed minor units of vuggy limestone conglomerate/boundstone FMI facies. Similarly in Antelope- 1 below the almost completely dolomitised section, low conductivity dolomites (Figure 11b) grade into vuggy limestone conglomerate/boundstone facies within a partially dolomitised zone (Figure 8; 1935-1976.2 m). The vuggy limestone conglomerate/boundstone facies typically consists of a generally distinct resistive or slightly conductive limestone fabric containing abundant conductive vugs and holes (Figure 12a \& b). Thick bedding is generally highly discrete yet visible because of very thin conductive layers that define probable bedding planes. Some 'clasts' are visible, but in places blur into the overall apparently fine to medium grained fabric on the image and form an internal structure suggestive of boundstone. Within this facies in Antelope-1 the more conglomeratic to fine to medium grained fabric prevails over the potential boundstone fabric. As seen on the FMI images the vuggy limestone conglomerate/boundstone has a similar character to the low conductivity dolomite, but is predominantly of limestone composition with up to $20-40 \%$ dolomite content.

The lowermost imaged portion of Antelope-2 (2211-2450 m) consists of vuggy limestone conglomerate with minor interbeds of fine-grained, thinly bedded limestone FMI facies (Figure $13 \mathrm{a}$ and $\mathrm{b}$ ). The vuggy limestone conglomerate is similar to the vuggy limestone conglomerate/boundstone described directly above, but lacks any internal 
structure suggestive of boundstone, contains fewer clasts, and has more distinct occasional thick bedding (Figure 13a). The fine, thinly bedded limestone facies consists of a thinly bedded limestone with a generally smooth appearance and low to medium overall conductivity (Figure 13b). Poor image quality in this lower portion of Antelope-2 commonly renders it difficult to distinguish the vuggy conglomerate facies from the fine, thinly bedded limestone with which it gradationally interbeds.

In Antelope-1 a generally resistive interval below the partially dolomitised zone consists of limestone conglomerate/boundstones in its lower half that generally grade upwards into fine mottled limestone FMl facies (Figure 14a; 1976.2-2060.3 m). The mottled limestone is imaged as massive to metre-scale beds of resistive spots and patches within a generally conductive mottled fabric. The limestone conglomerate/boundstone has a coarser texture than the mottled limestone with distinct resistive 'clasts' in a more conductive groundmass. An internal, wavy structure is common suggesting that boundstone is sometimes present. The interval between 2060.3 and $2246.6 \mathrm{~m}$ consists of six 'cycles' dominated by limestone conglomerate breccia occasionally gradationally interbedded with fine, medium-bedded limestone and limestone conglomerate/boundstone FMI facies (Figure 14b). Each cycle features an unconformity at its base, is upward coarsening, with resistive clasts more abundant towards the top, and capped by units with potential boundstone fabric (Figure 14b). The limestone conglomerate/breccia has elliptical resistive clasts, some with distinct conductive rims in a moderately conductive groundmass. The fine, medium-bedded limestones generally have a smooth, but sometimes brecciated appearance and are resistive to slightly conductive. The lower cycle (between 2126.4 and $2246.6 \mathrm{~m}$ ) is highly resistive and includes a number of potential boundstone units.

At $2246.6 \mathrm{~m}$ in Antelope-1 there is a distinct unconformity and below this in the lower imaged section (to $2454 \mathrm{~m}$ ) well-layered units are predominantly moderately conductive. Limestones conglomerate/breccia predominate between 2246.6 and $2347 \mathrm{~m}$ and are interbedded or gradationally bounded by fine, thinly bedded limestone FMI facies. Vice 
versa, fine, thinly bedded limestones with more minor medium-thickly bedded clastic limestones predominate between 2347 and $2454 \mathrm{~m}$. Limestone conglomerate/boundstones also feature between 2290.5 and $2300 \mathrm{~m}$. The succession has been subdivided on the basis of predominance of fine, or medium-thickly bedded facies and the presence of unconformities at 2291, 2300, 2311, 2316.4, 2320, 2325.6, 2336.8, 2377, 2381, 2389.5 and $2402.6 \mathrm{~m}$. The clastic limestones include subrounded resistive spots or clasts aligned parallel to bedding in a more conductive groundmass and are similar to those described above for the middle part of Antelope-1. In the lower Antelope-1 section, however, thin conductive layers are more common, and resistive clasts are generally smaller, less abundant, matrix- rather than clast-supported, and more elongate than in middle imaged section. The fine, thinly bedded facies are like those described above for the lower part of Antelope-2, but typically contain minor resistive clasts.

\section{Antelope-1 and 2 wells: Initial interpretation from FMI data}

The vuggy mottled limestone conglomerate/boundstone FMI facies that comprise the uppermost zone in Antelope-2 (1829-1939 m), due to its speckled appearance, presence of clasts and potential internal structure, was tentatively interpreted as fine-medium grained grainstone, with areas of potential boundstone and/or rudstone. The 'mottled' texture was related to layered micritic content, possibly in the form of algal laminations that may have been subject to stylolitisation/dissolution. An overall interpretation of shallow water reef deposit, from a possible reef flat, was on the basis of moderate to high energy (from the grainstones) together with the potential co-occurrence of algal laminae with coral boundstones and rudstones.

The almost completely dolomitised and underlying partially dolomitised zones in upper Antelope-1 (1732-1976.2 m) and middle Antelope-2 (1939-2211 m) have rudstone to boundstone fabrics with a fine-medium, potential grainstone, groundmass. This 
interpretation holds for five FMI facies: the low, moderate and highly conductivity dolomites, as well as the (vuggy) limestone conglomerate/boundstones (Figure 11a-e). However, dolomitisation and gas smearing, particularly in the high conductivity dolomite, does strongly obscure original depositional features, rendering conclusive interpretations difficult. Some of the thin conductive features interpreted mainly as bed boundaries may also be stylolites or dissolution seams (Figure 11d). The common vugs and holes may reflect primary preservation of intergranular or shelter porosity, and/or significant dissolution associated with dolomitisation, and/or of corals (Figure 11a-e). The high gamma readings in the high conductivity dolomite is a result of a high uranium content, not uncommon for dolomite, and associated with these almost completely dolomitised intervals (see footnote 1). For similar reasons to those listed above for the upper section of Antelope-2, these dolomitised and partially dolomitised deposits are also interpreted to be shallow water reef, potentially reef flat, deposits. The potential boundstone textures in Antelope-1 in the interval between 1976.2 and $2060.3 \mathrm{~m}$ was also thought to potentially be of reef flat origin, although the less clastic-rich upper mottled facies was perhaps deposited in a calmer water setting than the intervals above and below (Figure 14a). The potential boundstones that cap each of the six cycles between 2060.3 and $2246.6 \mathrm{~m}$ are also inferred to have reefal origins (Figure 14b). The elliptical clasts in the cycles are likely branching corals, with those having distinct conductive rims probably encrusted with coralline algae. Each cycle is interpreted to be due to increasing energy, and/or proximity to a reef probably reflecting upwards shallowing or lateral changes on a reef flat perhaps passing upwards into a reef crest environment. Moderate to high energies are inferred for much of these cycles due to the abundance of clasts (or reworked corals). The lowermost two cycles with the thickest boundstone caps may be predominantly reef crest deposits, or very proximal to this environment.

The rounded or elliptical clasts in the vuggy limestone conglomerate that predominates in the lowermost imaged portion of Antelope-2 (2211-2450 m) are interpreted to be reworked corals (Figure 13a). Due to its speckled appearance the groundmass to this 
facies is probably largely grainstone of fine to medium grain size. The absence of boundstone, but abundance of limestone conglomerate (or coral rudstone) are suggestive of an environment very proximal to a reef, but not part of the reef proper, i.e., reef fringe (of James, 1984). The majority of the facies could be considered coarse coral debris deposited in a reef fringe setting. The minor interbeds of fine, thinly bedded limestone within the lowermost interval of Antelope-2 were probably also deposited in a reef setting, albeit of less proximity to the reef, or during periods of less reworking from the reef. In Antelope- 1 the interval between 2246.6 and 2347 m dominated by limestone conglomerate/breccias is also interpreted to predominantly represent a reef fringe environment with minor reefal development between 2291 and $2300 \mathrm{~m}$. Within this zone facies dominated by clastic material are considered proximal debris to the reef, whereas the fine layered limestone facies are interpreted as more distal deposits. The predominance of fine, thinly bedded limestone in the lowermost imaged section in Antelope-1 (2347-2454 $\mathrm{m}$ ) is inferred to represent a relatively quiet water environment or one distal from a reef. The minor limestone conglomerate/breccia interbeds are probably coral debris deposits derived from an adjacent reef (as in the overlying section). These may have been emplaced during storms or other periods of increased wave activity, but could in some cases also be channel deposits. Overall, a backreef lagoon or toe of forereef slope environment is inferred for this lowermost interval.

\section{Antelope-1 and 2 wells: Petrology, comparison with FMI data and overall interpretation}

Overall, the comparative petrology and FMI data study yielded some agreement in the interpretation of depositional environments and sequence trends for Antelope-1 and Antelope-2. Following petrography, however, there was a significant change in depositional interpretation for the lower section of Antelope-2 that was generally poorly imaged via FMI, and also the uppermost section of Antelope-2, the former resulting in correction of a miscorrelation between the wells. Most other discrepancies between the original 
independent interpretations are attributable predominantly to diagenetic overprints that were not easily identifiable from the FMI logs alone. The petrology therefore proved critical in the Antelope wells to better understand depositional changes, complex diagenetic overprints, to provide calibration for the FMI data and in places to revise original FMI interpretations.

Upper Antelope-2 well: The upper part of Antelope-2 (1829-1939 m) had both whole cores (Core 1: 1835.06-1840.49 m, Core 2: 1846.09-1881.85 m) and 47 thin sections from core plugs and rotary sidewall cores available for comparison with the FMI logs (Figure 10). Following petrography the interpretation for this upper Antelope-2 interval changed from an overall shallow reef flat setting (original FMI interpretation) to moderate photic depths in an inter-reefal setting or one back from a reef crest, or perhaps less likely a forereef setting. The vuggy mottled limestone conglomerate/boundstone FMl facies comprising this upper part of Antelope-2 from both core and thin sections dominantly consists of bioclastic pack/grainstones and coral bioclastic rud/bound/pack/grainstones. Algal, coral and/or larger benthic foraminifera float/rud/pack/grainstones are subsidiary lithologies. The colour of the core varies from pale, to medium-grey with concentrations of dark grey insoluble material along dissolution seams and stylolites (Figure 10b, c, f, g \& h). Changes in lithology are gradational (or occur across dissolution seams) and clear bedding surfaces are rare. In thin section the bioclastic (coralline) pack/grainstones are generally medium to coarse-grained, though often heavily recrystallised (Figure $10 \mathrm{f} \& \mathrm{j}$ ). They include larger benthic, predominantly perforate, foraminifera, minor planktonic foraminifera, echinoderm, mollusc and coralline algal material. Many bioclasts are fragmented and abraded. Calcareous sponge spicules, bryozoa and barnacle material is also seen in some samples. The packstone matrix material includes micrite and non-carbonate material, possibly including very minor clays in darker grey areas. Packstone to wackestone textures are present in areas of dissolution seams and stylolites where fine matrix and insoluble material dominates. For the coral (\& coralline algal bioclastic and/or larger benthic foraminifera) $\mathrm{rud} /$ bound/(float)/pack/grainstone corals and rhodoliths are up to $30 \mathrm{~cm}$ across (Figure $10 \mathrm{c}$ ). 
Corals include branching and massive forms, and most are heavily affected by recrystallisation and/or dissolution then cementation (Figure 10d, I, j, k \& I). Laminar encrusting coralline algae encrust some of the corals (Figure 10h, I \& j). Many corals are reworked (e.g., bed parallel branching corals), although it is difficult to ascertain if others may be in growth position. Circum-clast dissolution seams and stylolites have formed around and between many recrystallised corals (Figure $10 \mathrm{~g} \& \mathrm{~h}$ ). The matrix to the $\mathrm{rud} / \mathrm{boundstones}$ consists of bioclastic pack/grainstone as described directly above. Although medium to coarse grained pack/grainstone are recognisable much of the core has a crystalline appearance (and this is also evident in thin section; Figure 10). Early dissolution, fracturing, solution enhancement of fractures and infill by siliciclastic sediment and dolomite crystal silt are common (Figure $10 \mathrm{~d} \& \mathrm{e}$ ). Mosaic to blocky non-ferroan calcite cements are prevalent partially infilling pore space, and in part post-date some mechanical compaction features. Intervals of wavy, wispy and anastomosing dissolution seams present at decimetre- to metre-scale intervals, are between a centimetre to $30 \mathrm{~cm}$ thick, and may be cross-cut by jagged stylolites, with amplitudes of up to $4 \mathrm{~cm}$. Dissolution seams and stylolites are mostly associated with finer intervals and orientated horizontally or inclined up to thirty degrees. Fractures are straight to irregular and typically oriented near vertical to 70 degrees and may have apertures up to $1 \mathrm{~cm}$ and be open, solution-enhanced, or closed and/or cemented. Minor late dolomite cements and a late phase of leaching is seen in many samples.

On the basis of the biota, their growth forms, common bioclast fragmentation and abrasion, as well as grain/rudstone textures deposition under normal marine, moderate to high energy conditions is inferred. Packstones and floatstones probably accumulated in lower energy areas, but still contain abundant fragmented and reworked shallow water biota. The setting was an area of, or in close proximity to, coral growth, i.e., reefal or near-reefal. As many of the corals are reworked, there is the possibility of an inter-reef, forereef or reefflat (back from the reef crest) setting. Stratal orientations and orientations of recrystallised 
corals were commonly difficult to obtain in the core. Reworked branching corals, dissolution seams and stylolites are commonly oriented perpendicular to the core axis and may therefore indicate, or enhance, near-horizontal bedding. However, not all surfaces that potentially relate to original bedding are horizontal, and there has been considerable structural deformation of the region and tilting of strata via thrusting since deposition (Goldberg and Holland, 2008). For these reasons, a forereef setting in which inclined bedding would normally be expected to prevail, cannot be ruled out. The thin sections do not have an abundance of biota distinctive of very shallow water depths such as common molluscs or imperforate foraminifera, and where present these are generally reworked. Foraminifera, such as robust (commonly abraded) Amphistegina are common. Spicules, bryozoa (and barnacles) are most common in current or tidal influenced areas with some nutrients, such as may occur in fore-, inter- or back-reef areas. The thick algal coating present on some of the corals would also be consistent, though not exclusive to, current swept areas with some nutrients. The observations of orientations, biota types and their preservation would be most consistent with moderate photic depths in an inter-reefal setting or one back from a reef crest, or perhaps less likely a fore-reef environment. The presence of planktonic foraminifera indicate open marine circulation. Influx of minor insoluble material could occur in both reef flat (possibly terrestrial-derived) or inter-reef and fore-reef settings (via currents). Most of the siliciclastic material was present as fissure fills (probably infilling karstic cavities) and/or concentrated along seams via compaction. It is likely that any karstification, fracturing and dissolution seam development may have enhanced the conglomeratic, brecciated or boundstone textures inferred from the FMI images.

Upper and middle Antelope-1, and middle and lower Antelope-2 wells: Results of petrography corroborated the overall predominant reef flat interpretation from the FMI for the upper pervasively dolomitised, partially dolomitised and middle predominantly undolomitised sections in Antelope-1 down to $2177.8 \mathrm{~m}$, as well as the middle pervasively and predominantly dolomitised portion of Antelope-2 (1955-2211 m). Following petrography 
the interpretation for much of the lower mainly undolomitised interval of Antelope-2, down to at least $2347 \mathrm{~m}$, was also modified to a predominantly reef flat setting, rather than a reef fringe environment as was originally inferred from the initial FMI analysis. A reefal to reef flat origin was also possible for the pervasively dolomitised zones, although alteration rendered distinction of these environments difficult. The large range in FMl textures throughout these reef flat-interpreted intervals that span the middle imaged portion of Antelope-1 and much of Antelope-2 reflects a combination of considerable variation in depositional textures linked to local environmental change on the reef flat, varied diagenetic overprinting (including dolomitisation and karstification) as well as differences in petrophysical properties.

All samples within the middle interval of Antelope-2 between 1955 and 2193 m are pervasively dolomitised (Figure 11; 34 samples), as are those from the upper interval of Antelope-1 (1748-1938 m; 38 samples). In Antelope-2 the lower boundary of the dolomitised zone may extend deeper (as is apparent from the FEQL), but no samples were available between 2193 and $2231 \mathrm{~m}$. Age diagnostic biota are generally absent from the dolomitised intervals in both wells, and $\mathrm{Sr}$ isotopic analysis yield unreliable ages (Allan, $\mathrm{T}$., pers. com., 2011). From petrography, the dolomitised intervals in both wells show very similar depositional and diagenetic features. Although pervasive dolomitisation commonly overprints earlier textures and features, recognisable depositional textures are wackestones, packstones, grainstones, floatstones and rudstones (Figure 11f-j). Boundstones may also be present as inferred from the FMI images, but this texture is at a larger-scale than identifiable in individual thin sections. Bioclasts, where recognisable, include locally very common branching or massive corals, imperforate foraminifera and molluscs (Figure 11f-j). Less common elements include disseminated or encrusting coralline algae, and Halimeda. Many bioclasts show some fragmentation and/or abrasion and may be replaced by dolomite, or are more commonly seen as leached moulds, with some infilling by dolomite cement (Figure 11f-j). In both wells there is a tendency for high- and moderate-conductivity dolomite FMI facies to correspond to coral-rich pack/grain/rudstones, although this is not systematic 
and there are also examples of wackestones with high-conductivity (Appendix 1). In terms of their diagenesis many samples show common micritisation of bioclasts, with micrite envelopes now outlining partially cemented biomoulds. Dissolution of aragonitic bioclasts occurred in some samples prior to 'dusty' dolomite rhombs pervasively replacing micritic matrix (Figure 11f-j). Early aragonite dissolution is associated with reddening and/or fine siliciclastic sediment infill (the later mainly in Antelope-2 samples) in a third of dolomitised samples from Antelope-1 and a lesser proportion of samples from Antelope-2. Sample 1964 $m$ in Antelope-2 includes a laminated and matrix-supported breccia infill to a linear cavity within a reddened dolomitised mollusc bioclastic packstone (Figure 11h). Leaching of calcite bioclasts commonly follows 'dusty' dolomite formation, and in turn is often followed by a clear phase of dolomite cement partially infilling pores. A localised, late phase of coarse, nonferroan poikilotopic calcite cement post-dates the clear dolomite cements (Figure 11g-i). Late leaching post-dates the clear dolomite cements and/or the poikilotopic calcite. Samples in Antelope-2 tend to have less leaching of calcitic bioclasts and/or the late calcite cements comprise a higher percentage (Figure $11 \mathrm{i}$; up to $15-25 \%$ ) of the sample than in Antelope-1. Consistent with the FEQL results, the presence of calcitic bioclasts and/or calcite cements is most common in the low and moderate conductivity dolomites in Antelope-2, makes up less than $10 \%$ of the high- and moderate-conductivity dolomites in Antelope-1 (typically as cements), and are generally absent from high-conductivity dolomites in Antelope-2.

Limited samples ( 6 between 2184 and $2193 \mathrm{~m}$ ) were available for study from the lower predominantly dolomitised section in Antelope-2 (2143.5-2211 m). Nine samples were available from the partially dolomitised zone in Antelope-1. The low conductivity dolomite FMl facies within this zone in Antelope-2 correspond to dolomitised bioclastic wacke/packstones rich in molluscs and similar to some of the mollusc-rich lithologies in the overlying pervasively dolomitised zone (Figure 11h). Dolomitised coral bioclastic pack/floatstones correspond to low conductivity dolomites from the partially dolomitised interval in Antelope-1, and again resemble lithologies from the upper pervasively dolomitised 
zone. Just below the pervasively dolomitised zone in Antelope-1 sample $1938.8 \mathrm{~m}$ is a recrystallised and fractured pack/floatstone with cavities that are partially infilled by fractured dolomitised micritic infill and dolomite cements (Figure 12c). The four samples corresponding to vuggy limestone conglomerate / boundstone FMI facies in Antelope-2 are partially dolomitised (coral) bioclastic wacke/pack/floatstones containing common coral, mollusc and some encrusting coralline algal material (Figure 12f-h). Disseminated coralline algal debris and imperforate foraminifera are also present in some samples. Corals are mostly branching forms and may be fragmented, or whole, with the latter showing little signs of abrasion. In comparison, vuggy limestone conglomerate / boundstones in Antelope-1 predominantly correspond to coral and coralline algae bioclastic grain/pack/rudstone showing common fragmentation and abrasion of bioclasts (Figure 12d-e). Bioclastic content is similar to that in the conglomerate / boundstones from Antelope- 2 in also containing imperforate foraminifera and molluscs. In the partially dolomitised zones from both Antelope-1 and -2 dolomitisation and calcite cements follow the same trends as those of the pervasively dolomitised samples, but are more patchy. For example, some samples show partial dolomitisation of matrix, minor dolomite cements and late poikilotopic calcite cements, whereas other samples have common clear dolomite cements partially infilling pores between calcitic bioclasts (Figure 12e-h). Sample $2184.1 \mathrm{~m}$ in Antelope-2 includes a laminated dolomitised micritic infill to an earlier possible dissolution or shelter cavity between corals (Figure 12f).

The fine-grained, thinly bedded limestone FMl facies in the lowermost imaged portion of Antelope-2 (2211-2450 m) consist of imperforate foraminifera and mollusc or algal grain/packstones (Figure 13c-d; 11 samples). The interbedded vuggy limestone conglomerate FMI facies may also consist of these same grain/packstone lithologies (6 samples), but are more commonly recrystallised corals (6 samples) or coral-rich bioclastic grain/pack/float/rudstones (Figure 13e-f; 9 samples). Minor wackestones (2372 m) and breccias (Figure 13g; some partially dolomitised) or heavily fractured samples (4 samples) 
are also present. Molluscs and imperforate foraminifera tend to be more common in the upper part of this lower imaged interval, and although corals are seen throughout they are abundant in the lower part of the interval. Perforate foraminifera, including Miogypsina, echinoderm debris and Halimeda are locally abundant within the lower imaged interval. Fragmentation and abrasion of bioclasts is seen in many, but not all samples. Two samples in this lower zone contain reworked carbonate lithic clasts (Figure 13g; 2289 and $2434 \mathrm{~m}$ ). Samples in this lower Antelope-2 interval are predominantly undolomitised. Minor dolomitisation is seen of micritic matrix to a breccia $(2289 \mathrm{~m})$, and as late cement in fractures (2283, 2294.5 \& $2422 \mathrm{~m})$. Early micritisation was followed by isopachous cements (sometimes multiple phases) particularly in the lower coral-rich samples below $2347 \mathrm{~m}$ (Figure 13e-f). Mottled texture (glaebules, alveolar texture) and Microcodium are early features in samples from around $2300 \& 2370 \mathrm{~m}$ (Figure 13g). Dissolution followed by extensive blocky cements and or neomorphic replacement of bioclasts plus blocky to drusy cements are extremely common (Figure 13c-d). Later diagenetic features include fracturing (sometimes multiple phases), further blocky to equant cementation, minor compaction and late dissolution plus rare dolomite cement precipitation.

In Antelope-1 from just below the partially dolomitised zone, the 3 samples corresponding to fine mottled limestone FMI facies are partially dolomitised coral float/rud/packstones or breccias (1983-1987.5 m). Dolomitisation has resulted in a 'network-like' fabric due to replacement of: (1) matrix between corals or molluscs, or (2) bladed cements between clasts in breccia (Figure 14c). Where dolomites replace the matrix of samples, the bioclasts have been leached out and their moulds infilled by poikilotopic calcite cements. Two more samples corresponding to fine mottled limestone FMI (2027 \& $2035 \mathrm{~m})$ are mollusc, imperforate foraminifera and coral bioclastic grain/packstones. Samples 1991-2189.79 m corresponding to limestone conglomerate/boundstones, massive, medium-bedded clastic and fine, medium bedded limestone FMI facies are all predominantly mollusc and imperforate foraminifera bioclastic pack/grainstones (Figure 14d-e). Corals are 
present in some of the massive, medium-bedded samples and are common in the limestone conglomerate /boundstone samples (Figure 14f). Larger perforate foraminifera, echinoderm debris and coralline algae are all also locally present in the middle interval of Antelope-1, with many bioclasts fragmented and abraded. Although pack/grainstones textures predominate, wackestones were also present at 2055, 2070, 2084, 2095, 2109, 2122.6 and $2166.8 \mathrm{~m}$ corresponding to the massive and fine medium bedded limestone FMl facies. Planktonic foraminifera are present in the wacke/packstones corresponding to fine- and massive-, medium bedded limestone FMI facies at 2095 and 2109 m. Between 2200 and 2239.2 m samples are coral-rich grain/rudstones and floatstones in which Halimeda, larger perforate foraminifera and coralline algae are all common (Figure 14f), whereas imperforate foraminifera and molluscs are rare. A number of samples mostly corresponding to limestone conglomerate/boundstone FMI facies in the middle imaged interval of Antelope-1 contain reworked non-carbonate and carbonate lithic clasts, including chert (Figure 14c \& f; Samples 1983, 2004, 2182 and $2228 \mathrm{~m}$ ). Samples in this middle Antelope-1 interval are partially dolomitised, to predominantly undolomitised. Early micritisation was followed by dissolution, rare isopachous (1983-1991, 2041, 2180, 2200-2228 m), or common blocky cements, some compaction and neomorphic cements (Figure 14c-f). Reworked clasts show highly varied diagenetic histories, including mottling, fracturing, reddening and partial dolomitisation. Reworking of clasts is associated with fracturing, brecciation, dissolution, sediment infill and neomorphic cements. Some reworked clasts are coated in isopachous cements and there may be multiple phases of these as well as multiple dolomitising episodes. Glaebular structure, Microcodium and cavity infills are seen at 2004.5, 2012.5, 2018, 2041, 2055, 2155, 2180 and $2182 \mathrm{~m}$, with most of these samples corresponding to limestone conglomerate /boundstones (Figure 14e). Later diagenetic features includes clear dolomite cement, chemical compaction, together with minor dedolomitisation, fracturing, late leaching and some sediment infiltration \&/or micritisation of pore spaces. 
Evidence for the reef flat interpretation of Antelope-1 down to $2177.8 \mathrm{~m}$, as well as the middle of Antelope-2 (1955-2211 m) includes common reworked and potentially in situ corals, the latter inferred from FMl investigation, together with abundant imperforate foraminifera and molluscs that are very common shallow photic elements. There was local reworking of corals possibly from the inferred reef flat setting or a nearby reef crest, but it appears there was also some reworking of carbonate and non-carbonate clasts across the reef flat. Some of the resistive 'clasts' seen on FMI may therefore represent actual 'clasts' rather than being exclusively corals. Much of this reef flat experienced moderate to high energy conditions as indicated by the predominance of grainstone and rudstone textures. However less common wackestone and floatstones reveal that local areas, or periods, were affected by lower energy conditions. Although tentative energy regimes were assigned following the FMI analysis, there are a number of examples where these interpretations were modified after petrography. For example, a possible relatively calm water setting was inferred from predominantly 'clastic-free' mottled FMI textures in the upper part of the 1976.2-2060.3 m interval in Antelope-1. Following petrography many of the samples from this mottled interval were revealed to be cemented grainstones and breccias or conglomerates indicative of moderate to high energy conditions. Petrology also revealed that, at least in part, the mottled FMI texture is attributable to partial dolomitisation of cements, and/or matrix of a probable earlier karstified zone. Multiple samples in both Antelope wells from the reef flat zones show a range of features collectively indicative of subaerial exposure including Microcodium, alveolar and/or glaebular textures, early aragonite dissolution associated with reddening, and laminated micritic, siliciclastic, or brecciated infills to irregular dissolution cavities (Esteban and Klappa, 1983). This evidence for multi-phase exposure and karstification was not deciphered from the initial FMI analysis. Some of the brecciation, mottling and conglomeratic/ boundstone textures seen in FMI when compared with corresponding thin sections, were attributable, at least in part, to exposurerelated features. The vuggy limestone conglomerate / boundstone and conglomerate FMI facies appear to have multiple origins as coral and/or lithoclastic rudstone, floatstones or 
breccias, potential boundstones as well as corresponding to karstic features or zones. Following petrology there was some minor movement of internal facies zone boundary changes within the overall inferred reef flat deposits. Originally the change from predominantly reef flat to underlying reef flat cycles was picked at a prominent boundary at $2060.3 \mathrm{~m}$ on the FMl Antelope-1 images. After petrology a 'sequence' boundary was preferred at a prominent slightly irregular boundary at $2055.1 \mathrm{~m}$. The conductive zone just above $2055.1 \mathrm{~m}$ contains planktonic foraminifera and probably reflects open marine and slightly deeper water conditions, i.e., localised evidence for marine incursion/flooding within the reef flat deposits, hence picking the boundary just below this. On the basis of textural evidence from samples the energy regime for the five reef flat cycles identified from FMI between 2055.1 and $2177.8 \mathrm{~m}$ varied, although moderate to high energies predominated. Cycles are interpreted to reflect changes in energy and or relative water depth with some of the cycles probably shallowing upwards to bound/rudstone textures and/or zones with evidence for subaerial exposure.

The highly resistive lowermost reefal-associated cycle in Antelope-1 identified during FMI analysis (2177.8-2246.6 $\mathrm{m}$ ) is now interpreted predominantly as reef crest deposits due to the number of potential boundstone units (from FMI), abundance of corals, but paucity of common reef flat elements such as imperforate foraminifera or molluscs. Robust perforate foraminifera, coralline algae and Halimeda are all also consistent with, though not exclusive to, a reef crest setting. Samples from this interval are the main ones to show thick, isopachous or bladed cements rimming corals, or other bioclasts, a feature common in reef crest areas in which significant cementation is associated with flushing of marine waters through platform margin deposits (cf. Flügel, 2004). The lowermost imaged portion of Antelope-2 (2347-2450 m) is also rich in corals, Halimeda, perforate foraminifera, coralline algae and many samples also show the thick isopachous rimming cements. Some grainstone units rich in imperforate foraminifera also occur below $2347 \mathrm{~m}$ and overall these deposits are interpreted as reef crest to reef flat. Following petrology the lower 
predominantly undolomitised imaged third of Antelope-2 (2211-2467 $\mathrm{m}$ ) is now correlated with the middle (perhaps down to $2246.6 \mathrm{~m}$ ), rather than lower imaged portion of Antelope-1 (the latter was originally inferred from the initial FMI interpretation). Subsequent dating via biostratigraphy and $\mathrm{Sr}$ isotope analysis also revealed that the lower imaged third of Antelope-2 is age equivalent to the middle imaged portion of Antelope-1, with both yielding Early to Middle Miocene ages (Tony Allan, pers. comm., 2011).

Lower imaged Antelope-1 well: Following petrography of samples from the lower imaged portion of Antelope-1 some modifications were made to the initial interpretation from FMI of a predominantly reef fringe environment $(2246.6-2347 \mathrm{~m})$ with minor reefal development (2290.5-2300 m), and backreef lagoon to toe of forereef slope environment $(2347-2454 \mathrm{~m})$. Below the unconformity at $2246.6 \mathrm{~m}$ the medium-thickly bedded clastic limestones mainly correspond to coarse-grained larger benthic foraminifera bioclastic packstones, with subsidiary grain- or floatstone textures. Larger benthic foraminifera commonly have thin, flattened morphologies, but abraded more robust forms are also seen. Echinoderm debris, coralline algae and bryozoa are also common components, and corals or carbonate lithoclasts (or fine carbonate infills to burrows) are more minor components (Figure 15b-c). Samples of the fine, thinly bedded limestone FMI facies include similar bioclasts to the medium-thickly bedded FMI facies, but are generally fine- to medium-grained echinoderm bioclastic packstones, with lesser amounts of larger benthic foraminifera, and in which abraded branching corals are very rare to absent (Figure 15d). Planktonic foraminifera are locally present in the lower imaged portion of Antelope-1, but are most common in fine, thinly bedded FMl facies at 2323.5 and $2409 \mathrm{~m}$. From the biotic assemblages, and their morphologies, it was possible to infer relative depth within the photic zone for many of the deposits (thin flattened perforate foraminifera common in deeper photic depths and robust forms in shallower depths; Hallock \& Glenn, 1986; van Gorsel, 1988; Beavington-Penney \& Racey, 2004). Also, since many units lacked corals, and nonframework building bioclasts dominate, the deposits are described as platform deposits, 
rather than being necessarily linked to reefal systems as in the original FMI interpretation. Between 2246.6 and $2454 \mathrm{~m}$ the environment is predominantly moderate to deeper photic depth deposits, with or without significant reworking of shallow bioclastic material, plus or minus reworked corals.

There was a change in interpretation of the limestone conglomerate/boundstones FMI facies between 2290.5 and $2300 \mathrm{~m}$ where three corresponding samples are coral, lithoclastic and larger benthic foraminifera rud/float/grainstone-breccias. A depositional breccia origin with a range of reworked lithified carbonate clasts and corals is now preferred for much of this unit (Figure 15e). Development of a coral boundstone over the breccia cannot be totally ruled out, although lithic clasts as well as corals are seen in thin section at the top of the interval. That moderate to deeper photic depth deposits underlie and overlie the breccia is consistent with a sediment gravity flow origin for the whole unit, and an upper boundstone cap is less likely. Resistive areas in the lower part of the unit may reflect highly cemented clasts rather than mudstone or wackestone lithologies.

Isopachous and equant as well as neomorphic calcite cement are present in the rudstone breccia samples. Very minor thin isopachous cements are also seen around selected bioclasts in a few samples, but are mainly absent from the lower imaged interval of Antelope-1. Minor micritisation of bioclasts is common throughout the lower imaged portion of Antelope-1, as are syntaxial overgrowths on echinoderm material. Mechanical and chemical compaction features in the form of grain deformation, breakage and suturing are common throughout the lower interval. Blocky to equant cements between bioclasts, fracturing, very minor dolomite replacement of matrix or clear dolomite cements and late leaching are all minor localised features in this lower interval. As with the Elk wells, the diagenetic features in the lower part of Antelope-1 are mainly burial related, and with the exception of the minor cements and compaction-enhanced lamination for the most part do not significantly affect the depositional fabrics imaged by FMI. 
Final subdivision of the entire lower imaged portion of Antelope-1 into 5 environmentally distinct normal marine zones was on combined key FMl and petrographic characteristics (Figure 8). A faulted contact at $2347 \mathrm{~m}$ was no longer considered as a facies zone boundary. The key characteristics used for subdivision are: ratios or predominance of thinly bedded conductive (wacke/packstones) to more massive resistive units (pack/grainstones) with or without resistive patches (reworked cemented corals or clasts), and brecciated units. The predominant packstone depositional textures, together with some abrasion and fragmentation of disseminated bioclasts are indicative of mainly moderate energies on the platform. Less common grainstone textures may reflect some winnowing by wave-, storm-, or current-generated flow, or perhaps higher, local biotic productivity than micrite accumulation. Between 2290-2302 and 2396-2445 m there is evidence for reworking of previously lithified carbonate material. Between 2246.6 and $2449.5 \mathrm{~m}$ most deposits are interpreted as deep- to moderate-photic platform deposits. With a minor or localised component of reworked branching corals (and/or large resistive spots) deposits are largely inferred to be distal to any potential reefal development. The interval between 2340$2389.5 \mathrm{~m}$ is an exception being characterised by predominantly coral-rich bioclastic pack/grain/rudstone (clastic resistive FMI units) with subsidiary conductive, thinly bedded FMI units (probable bioclastic wacke/packstones). Deep to moderate, or perhaps shallower photic depths are inferred. There is general agreement in interpretation of depositional environment (proximal reef fringe with reworking of corals and other shallow bioclasts via storms or channels) from independent FMI and petrology studies. The interval between 2300 and $2340 \mathrm{~m}$ has evidence for punctuated shedding of bioclastic-rich material from shallower water, and/or localised shallowing of the environment, albeit still distal from any potential reefal development. Between 2389.5 and $2454 \mathrm{~m}$ resistive (wacke/pack/floatstones) interbed with conductive (pack/float/rudstone) units containing common resistive clasts. Some of the resistive patches may be lithified carbonate clasts (seen in thin section) as well as corals. A moderate- to deep-photic inner-, or outer-, platform margin/slope environment is inferred with reworking from higher energy, i.e., there 
is good agreement with the backreef lagoon or toe of forereef slope from the original FMI study. There may be a facies boundary at $2449.5 \mathrm{~m}$, into shallow photic deposits (inferred from petrology with samples extending down to $2668 \mathrm{~m}$ ). However, since the FMI image only extends to $2454 \mathrm{~m}$ a basal boundary was not picked. Throughout the lower imaged interval of Antelope-1 identified bed surfaces may be depositional in origin, but compaction related dissolution seams formed during diagenesis probably enhance the thinly- to mediumbedded appearance seen on FMI. Results of biostratigraphy and strontium isotopic analysis both yielded Late Oligocene to Early Miocene ages for the lower imaged portion of Antelope1.

\section{Discussion}

Akbar et al. (1995) stated that 'image [logs] are no substitute for core analysis, but rather a complement to them'. In this study, where very limited fullbore core was available, a FMI image analysis study was complemented by petrographic study predominantly of rotary sidewall cores. This combined study allowed enhanced definition of micro- to sequencescale variations in depositional and diagenetic character than would have been possible from either 'stand-alone' study (Figure 16). On a centimetre- to sequence-scale, FMI analysis allowed evaluation of combined depositional and diagenetic textures, clasts, boundaries and stratal trends (of individual beds and sequences). On a micro- to grainscale, petrography enabled analysis of components, depositional textures, microfacies, diagenetic overprints and their relative timing. In general, the petrography allowed detailed definition of depositional environments (from components and primary textures) and diagenetic alteration, albeit of multiple spot samples, whereas likely large-scale variations in depositional environments and sequences were assessable via image analysis.

Despite the obvious scale differences between the datasets there was adequate correlation between the independent petrography and FMI studies for: a) picking major 
facies boundaries, and b) interpretation of depositional environment for the slope and basinal deposits. However, for the shallow water carbonates where diagenesis had strongly impacted the original fabric, and/or in regions of gas smearing petrology proved critical in enhancing or revising original interpretations based on FMI, and particularly for understanding diagenetic overprinting. In the case of picking, or adjustment of, more minor facies boundaries, such as defining those between potential reef-flat versus reef-crest deposits, or recognising minor platform-top flooding events, the follow-up petrography proved critical. In the Elk wells that penetrated platform slope and bathyal deposits there was generally moderate agreement in defining depositional environments and up-sequences changes from the independent FMI and petrology studies. From petrography it was apparent that the slope and bathyal deposits had mainly been affected by burial diagenesis, in which primary depositional fabrics had been unaltered, 'tightened' (such as via circum-clast stylolites in breccias), or enhanced (such as dissolution seam development along lithological boundaries). Petrology proved essential in unravelling non-unique origins for some of the features seen in FMI. Laminations seen in a number of the FMl facies from the Elk wells have multiple origins including: (a) bed parallel bioturbation, (b) development of dissolution seams and perhaps other compaction related features, (c) interlamination of units richer in reworked shallow bioclasts, and (d) layer parallel silicicification. Non-pervasive, patchy dolomitisation in deposits from the Elk wells resulted in minor blurring (of clast margins) and perhaps mottling on the FMI images.

In the shallow-water deposits penetrated by the Antelope wells although there was some agreement in defining depositional environments from the independent FMI and petrographic studies, differences were often due to diagenetic overprinting. The often complex cementation, replacement and compaction events affecting the shallow-water deposits discernable from petrography commonly had a strong impact on textures seen in FMI. This diagenetic overprinting due to marine, meteoric and burial diagenesis, as well as dolomitisation would have been difficult or impossible to extract from the FMI data without the benefit of the petrographic work. Other core-image analysis studies have allowed direct 
correlation between FMI textures and Dunham's depositional carbonate textures (of mudstones, wackestones, packstone, grainstones and boundstones; Roestenburg, 1994; Akbar et al., 1995; Basu et al., 2002; Russell et al., 2002). This was only possible, however, if the grains, matrix and primary pores have maintained their depositional character, and/or been affected by a systematic diagenetic overprint (Roestenburg, 1994; Russell et al., 2002). In the Elk/Antelope wells it was commonly possible to pick depositional textures from the FMI fabrics particularly for coarser facies, such as rudstones or boundstone, or for finer slope or bathyal deposits, such as mud/wackestones or packstones. However, for the shallow-water deposits from the Antelope wells classifying mud-, wacke-, pack-, or grainstones from the FMI commonly proved difficult due to variable down-hole cementation, leaching, dolomitisation or karstification. For example, there were a number of cases where inferred calm water deposition from FMl analysis turned out to be predominantly high energy, but cemented, grainstone deposits during petrographic analysis. It may be that an iterative process of using the petrographic results to search for subtle differences in FMI textures may help differentiate the finer grained depositional textures (Russell et al., 2002), but the significant down-hole variations in diagenesis in the Antelope wells are likely to hamper such studies. The significant number of thin sections evaluated for this study allowed understanding that individual FMI textures or facies may represent multiple depositional and/or diagenetic features (cf. Nurmi et al., 1990). This study highlights the requirement for thin section analysis to be undertaken in tandem with image analysis to evaluate potentially non-unique origins for carbonate FMI textures. For example, conglomerate/boundstone FMI facies in the Antelope wells had multiple origins as rudstones, floatstones, lithoclastic conglomerates, boundstones and karstified grainstones or packstones. Fine-medium and coarse conglomerate/breccias in the Elk wells had multiple origins as packstones, rudstone, breccias, floatstones or dolomitised packstones. Again it may be that iterative training of FMI interpretation through input of the petrographic results would help reveal subtle differences in FMI textures to differentiate varied origins. 
Although not detailed here, the FMI and petrographic studies were both key analyses for characterising and understanding reservoir quality development. As with the depositional and diagenetic evaluation, the $\mathrm{FMI}$ and petrographic data complemented each other in allowing pore systems to be detailed on a variety of scales (Nurmi et al., 1990; Chitale et al., 2010; Xu, 2010), and the integrated study resulted in significantly increased understanding of reservoir quality development than was possible from the individual studies. Pores, and their morphologies, were characterised on grain- to cavern-scales. Porosity distribution, abundances and pore connectivity was assessed on micro- to sequence-scales. The origins of pores over one centimetre in size were tentatively inferred from the FMI study, and where possible corroborated from the limited fullbore core available. One of the advantages of running FMI was that pore system characterisation was possible in zones of high porosity and/or large pore systems, i.e., key reservoir intervals, in which recovery of fullbore, or sidewall, cores may be compromised. Greater certainty was possible in inferring controls on porosity development on the sub-centimetre scale from petrology, particularly when results were combined from geochemical and other microscopy studies (Wilson, pers.obs.). The combined outputs from the FMl and petrological reservoir evaluations were used as key inputs in defining petrophysical Reservoir Rock Types (RRTs), together with understanding and predicting their distribution for building reservoir models (Grötsch and Mercadier, 1999; Akbar et al., 2000/1; Russell et al., 2002; Ahr et al., 2005). In summary, the combined FMI and petrographic analyses resulted in significantly enhanced understanding of deposition, diagenesis and reservoir development in the Elk/Antelope system than would have been possible from either of the individual 'stand-alone' studies (Figure 16).

\section{Conclusions}

A combined down-hole image analysis (FMI) and predominantly side-wall core petrographic study of the Elk/Antelope carbonate reservoir from Papua New Guinea allowed enhanced definition of micro- to metre-scale variations in depositional and diagenetic 
character. Both shallow-water and platform flank deposits from this Tertiary carbonate buildup that is a major recent gas discovery were evaluated via a full suite of FMI logs (> $2800 \mathrm{~m})$ and 292 thin sections.

Image analysis and petrographic comparisons: Studies of the two independent datasets allowed complementary enhanced evaluation of micro- to sequence-scale variations in depositional and diagenetic character of platform and reservoir development. Despite the obvious scale differences between the datasets there was some correlation between the independent petrography and FMI studies for: a) picking major facies boundaries, and b) interpretation of depositional environment, particularly of flank deposits. However, where diagenesis had strongly impacted original fabric, as is commonly the case in these and other ancient shallow-water carbonates, or where gas smearing affected image quality, petrography proved key to evaluate depositional and diagenetic trends and their impact on petrophysical properties. Component analysis and depositional textures best identified in thin section, but partially inferable from image logs, are good indicators of original depositional environment. The petrographic study allowed more detailed examination of diagenesis and its impact on rock fabric (which links to the FMI textures). Full FMI coverage allowed textural definition on a $\mathrm{dm} / \mathrm{m}$ scale, identification and characterisation of vertical changes, and likely large-scale variations in depositional environments and sequences. By combining the results of the two studies it was clear that diagenesis as well as depositional fabric had a strong impact on resultant FMI facies, particularly for the shallow-water deposits. This study shows that selective petrographic analysis is critical to revise and/or enhance the quality of facies interpretation from FMl images.

Shallow-water carbonate buildup development and diagenesis: FMI logs and thin sections through the Antelope-1 and -2 wells allowed characterisation of close to 1000 $\mathrm{m}$ of much of the Oligo-Miocene development of the shallow-water buildup. Oligocene deposition was predominantly on a relatively open platform within the photic zone, and 
perhaps not always associated with localised or more extensive reefal development. Echinoderm and larger benthic foraminifera packstones with or without minor reworked coral debris are imaged on FMI as 'conglomeratic' and 'fine' medium- and thinly-bedded limestones. By the latest Oligocene and into the Early Miocene coral-rich rudstones and boundstones attest to reefal development in a probable reef-crest environment. Most of the remaining Miocene deposits are probable reef-flat deposits rich in imperforate foraminifera and molluscs, with punctuated potential coral reefal development. These Miocene deposits are dominated by grainstones and rudstones indicative of high to moderate energies, although packstones and less commonly wackestones are also present. Miocene deposits were imaged on FMI as: (a) low-, (b) moderate-, and (c) high-conductivity vuggy dolomite conglomerate/boundstones, as well as (i) mottled limestones, (ii) vuggy, and (iii) non-vuggy limestone conglomerate/(iv) boundstones or (v) conglomerate/breccias together with (vi) fine, medium-bedded 'fine' limestones. There was generally good agreement in inferring reef-flat and crest environments from the independent FMI and petrographic studies, with the coarser textures such as boundstones and rudstones, and depositional cycles more easily identifiable from FMI. Where differences in interpretations from the datasets mainly occurred, such as in inferred depositional energies or attributing most FMI features to primary depositional fabrics, was mainly due to the complex and varied diagenetic overprints that were only mainly discernable from petrography. Diagenetic overprinting includes complex and varied calcite cements, early and late dissolution, karstification, replacement, dolomitisation and compaction. The uppermost carbonate section in Antelope-2 consists of vuggy mottled limestone conglomerate/boundstone FMI facies, corresponding to (coral) bioclastic pack/grain/rud/boundstones that were not present in Antelope-1. Moderate photic depth inter-, back-, or less likely fore-reef deposits are inferred for the uppermost Antelope-2 section, with some differences in interpretation from the two datasets again mainly attributable to diagenetic overprinting.

Platform flank and associated bathyal deposition and diagenesis: The combined FMI and petrographic study of the Elk-1 and -2 wells allowed characterisation of $\sim 800 \mathrm{~m}$ of 
Miocene carbonate slope and associated bathyal deposits flanking the Antelope buildup. There was generally strong agreement in interpreting an overall deepening-upwards upperslope to bathyal depositional environment (and within this three smaller-scale deepeningupwards cycles) for both wells from the two independent datasets. FMI facies of (a) marls, (b) argillaceous-laminated, (c) laminated-, and (d) nodular thinly-bedded limestones correspond respectively to planktonic foraminifera-rich: (i) marls or mud/wackestones, (ii) wacke/packstones, (iii) (coral), and (iv) bioclastic packstones. From the marls to planktonicforaminifera bioclastic packstones these all represent bathyal deposits, but sequentially reflect shallowing, and/or increasing proximity to, or periods of bioclast shedding from, the adjacent shallow-water carbonate buildup. (a) Fine-medium- and (b) coarse limestone conglomerate/breccia and (c) medium to thickly bedded limestone FMI facies as discrete beds or more continuous sections variably correspond to bioclastic (including coral and planktonic foraminifera) grainstones, packstone, rudstones, floatstones and lithoclastic breccias that were deposited as slope and/or sediment gravity flow deposits. Since these slope and bathyal deposits were mainly affected by burial diagenetic features that either had little affect on, or enhanced, primary depositional textures there was strong correspondence in depositional interpretation from FMI and petrography. FMI analysis best revealed bed and/or sequence trends, as well as coarser-scale fabrics, whereas petrography allowed determination of components, depositional textures and diagenesis. Petrography revealed that some imaged structures (e.g., fine lamination) and individual FMI facies (e.g., the limestone conglomerate/breccias) may have multiple origins.

As has been stated (Akbar et al., 1995), 'image [logs] are no substitute for core', or in this case other sample (sidewall core petrography) 'analyses, but rather a complement to them'. This study highlights the merits of selective petrographic analysis to revise and/or enhance the quality of facies interpretation from FMI images, whether this is for inferring depositional environments, particularly for understanding diagenetic overprinting, or the evaluation of reservoir quality. 


\section{Acknowledgements}

We thank InterOil Australia Pty Ltd. and SPI (208) Ltd., Papua New Guinea for supporting this study and allowing publication. Initial FMI characterisation and analysis was undertaken by Dale Lewis at Schlumberger Oilfield Australia Pty. Ltd., Perth. Petrology and comparison of results with FMl was by Moyra Wilson. Scott Rothwell (InterOil) is thanked for his technical assistance in sample and data retrieval. Nigel Deeks is thanked for commenting on the draft manuscript. We thank Associate Editor and reviewers Alex MacNeil and Stephen Kaczmarek for their constructive comments during revision of this manuscript. This is for Megan - who loves life, with all its colours, textures and complexity!

\section{References}

Adams, C.G., 1970. A reconsideration of the East Indian Letter Classification of the Tertiary: British Museum of (Natural History), Geology 19, 87-137.

Ahr, W.H., Allen, D., Boyd, A., Bachman, H.N., Smithson, T., Clerke, E.A., Gzara, K.B.M., Hassall, J.K., Murty, C.R.K., Zubari, H. and Ramamoorthy, R. 2005. Confronting the carbonate conundrum. Schlumberger Oilfield Review 17, 18-29.

Akbar, M., Petricola, M., Watfa, M., Badri, M., Charara, M., Boyd, A., Cassell, B., Nurmi, R., Delhomme, J.-P., Grace, M., Kenyon, B. and Roestenburg, J. 1995. Classic interpretation problems: evaluating carbonates. Schlumberger Oilfield Review 7, 3857.

Akbar, M., Vissapragada, B., Alghamdi, A.H., Allen, D., Herron, M., Carnegie, A., Dutta, D., Olesen, J.R., Chourasiya, R.D., Logan, D., Stief, D., Netherwood, R., Russell, S.D. and Saxena, K. 2000/2001. A snapshot of carbonate reservoir evaluation. Schlumberger Oilfield Review 12 (Winter 2000/2001), 20-41.

Basu, T., Dennis, R., Basu, D., Al Awadi, W., Isby, J.S. and Muherjee, R. 2002. Automated facies estimation from integration of core, petrophysical logs, and borehole images. 
American Association of Petroleum Geologists Annual Meeting, Houston, USA. Extended Abstracts $7 \mathrm{p}$.

Beavington-Penney, S.J. and Racey, A., 2004. Ecology of extant nummulitids and other larger benthic foraminifera: applications in palaeoenvironmental analysis. Earth Science Reviews 67, 219-265.

Blow, W.H., 1969. Late Eocene to Recent planktonic foraminiferal biostratigraphy. Proceedings 1st Plankt. Conf., Geneva 1967, 1, 199-422.

Blow, W.H., 1979. The Cainozoic Globigerinida. Brill, E.J., Leiden, 1412 p.

Chitale, V.D., Johnson, C., Entzminger, D. and Canter, L. 2010. Application of a modern electrical borehole imager and a new image interpretation technique to evaluate the porosity and permeability in carbonate reservoirs. In: Pöppelreiter, M., GarcíaCarballido, C., and Kraaijveld, M. (eds). Dipmeter and borehole image log technology. AAPG Memoir 92, 295-307.

Davies, H.L., Winn, R.D. and KenGemar, P. 1996. Evolution of the Papuan Basin - a View from the Orogen. In: Buchanan, P.G. (Ed). Petroleum Exploration, Development and Production in Papua New Guinea. Proceedings of the Third PNG Petroleum Convention, Port Moresby, 245-270.

Dickson, J.A.D., 1965, A modified staining technique for carbonates in thin section. Nature $205,587$.

Dickson, J.A.D., 1966. Carbonate identification and genesis as revealed by staining. Journal of Sedimentary Petrology 36, 491-505.

Dunham, R.J., 1962. Classification of carbonate rocks according to depositional texture. In: Ham, W.E. (Ed.), Classification of carbonate rocks. American Association of Petroleum Geologists, Memoir, 1, 108-121.

Embry, A.F. and Klovan, J.E. 1971. A late Devonian reef tract on northeastern Banks Island, Northwest Territories. Canadian Petroleum Geologist, Bulletin 19, 730-781. 
Esteban, M., and Klappa, C.F., 1983. Subaerial exposure. In: Scholle, P.A., Bebout, D.G., and Moore, C.H., (Eds.), Carbonate Depositional Environments. American Association of Petroleum Geologists, Memoir 33, 1-55.

Flügel, E., 2004, Microfacies of carbonate rocks. Analysis, interpretation and application; Springer-Verlag, Berlin, $976 \mathrm{p}$.

García-Carballido, C., Boon, J., and Tso, N. 2010. Data management and quality control of dipmeter and borehole image log data. In: Pöppelreiter, M., García-Carballido, C., and Kraaijveld, M. (eds). Dipmeter and borehole image log technology. AAPG Memoir 92, 39-49.

Goldberg, A., and Holland, D. 2008. Inversion tectonics and the structural development of the Elk/Antelope Gas Field, Papua New Guinea. In: Blevin, J.E., Bradshaw, B.E., and Uruski, C., (Eds), Eastern Australasian Basins Symposium III, Petroleum Exploration Society of Australia, Special Publication, 247-258.

Goldberg, A. Wilson, M.E.J. and Sioni, S. 2010. Quantitative seismic interpretation for characterizing carbonate diagenesis - an Elk/Antelope Gas Field Study. ASEG extended abstracts. 4 p. DOI: 10.1071/ASEG2010ab128.

Grötsch, J., and Mercadier, C., 1999, Integrated 3-D reservoir modeling based on 3-D seismic: The Tertiary Malampaya and Camago buildups, offshore Palawan, Philippines. American Association of Petroleum Geologists, Bulletin 83, 1703-1728.

Hallock, P. and Glenn, E.C., 1986. Larger foraminifera: a tool for paleoenvironmental analysis of Cenozoic carbonate depositional facies. PALAIOS 1, 55-64.

Harris, D.G., Mahoney, R.J. and Braaten, K.M. 2009. InterOil Corporation resource assessment: Elk/Antelope. GLJ Petroleum Consultants, Calgary, (www.interoil.com/faq/Elk_Antelope_Gas_Field_2009_GLJ_-_FINAL.PDF -, accessed 30/04/2012). 51 p.

James, N.P., 1984, Reefs. In: Walker, R.G (Ed.), Facies Models, Geological Association of Canada, 229-244. 
Lagraba, P., Hansen, S.M., Spalburg, M., and Helmy, M. 2010. Borehole image tool design, value of information, and tool selection. In: Pöppelreiter, M., García-Carballido, C. and Kraaijveld, M. (eds). Dipmeter and borehole image log technology. AAPG Memoir 92, 15-38.

Lunt, P. and Allan, T., 2004. A history and application of larger foraminifera in Indonesian biostratigraphy, calibrated to isotopic dating. GRDC Workshop on Micropalaeontology, 109 p.

McArthur, J.M. and Howarth, R.J., 2004. Strontium isotope stratigraphy. In: Gradstein, F.M., Ogg, J.G. and Smith, A.G. (Eds.), A Geologic Time Scale 2004, Cambridge University Press. pp. 96-105.

McArthur, J.M., Howarth, R. and Bailey, T.R., 2001. Strontium Isotope Stratigraphy: LOWESS version 3. Best fit line to the marine Sr-isotope curve for 0 to $509 \mathrm{Ma}$ and accompanying look-up table for deriving numerical age. Journal of Geology 109, 155-169.

Newberry, B.M., Grace, L.M. and Stief, D.D. 1996. Analysis of Carbonate Dual Porosity Systems from Borehole Electrical Images. SPE paper no. 35158, p. 1-7.

Nurmi, R., Charara, M., Waterhouse, M. and Park, R. 1990. Heterogeneities in carbonate reservoirs: detection and analysis using borehole electrical imagery. In: Hurst, A., Lovell, M.A. and Morton, A.C. (Eds.). Geological Applications of Wireline Logs. Geological Society of London Special Publication 48, 95-111.

Pigram, C.J. \& Davies, H.L. 1987. Terranes and the accretion history of the New Guinea Orogen. BMR Journal of Australian Geology \& Geophysics. 10, 193-211.

Pigram, C.J., Davies, P.J., Feary, D.A. and Symonds, P.A. 1989. Tectonic controls on carbonate platform evolution in southern Papua New Guinea: Passive margin to foreland basin. Geology 17, 199-202.

Rider, M.H. 2002. The geological interpretation of well logs $\left(2^{\text {nd }}\right.$ edition). Rider-French Consulting Ltd, Scotland, 280 p. 
Roestenburg, J.W. 1994. Carbonate characterisation and classification from in-situ wellbore images. Proceedings of the Indonesian Petroleum Association, $23^{\text {rd }}$ Annual Convention, Jakarta, Indonesia. 181-188.

Russell, S.D., Akbar, M., Vissapragada, B. and Walkden, G.M. 2002. Rock types and permeability prediction from dipmeter and image logs: Shuaiba reservoir (Aptian), Abu Dhabi. American Association of Petroleum Geologists, Bulletin 86, 1709-1732.

Schlumberger. 2004. Schlumberger WTA Marketing Service: FMI Fullbore Formation Microlmager: Houston, Texas, Schlumberger Educational Services, 2 p.

Struckmeyer, H.I.M., Yeung, M. and Pigram, C.J. 1993. Mesozoic to Cainozoic plate tectonic and palaeogeographic evolution of the New Guinea Region. In: Carman, G.J. and Carman, Z. (Eds). Petroleum Exploration and Development in Papua New Guinea, Proceedings of the Second PNG Petroleum Convention, Port Moresby, 261-290.

van de Vlerk, I.M., Umbgrove, J.H.F. 1927. Tertiaire gidsforaminifern van Nederlandsch Oost-Indiè. Wetenschappelijke Mededeelingen Dienst avn den Mijnbouw in Nederlandsch Oost-Indiè 6, 3-31.

van Gorsel, J.T., 1988. Biostratigraphy in Indonesia: Methods, pitfalls and new directions. Proceedings of the Indonesian Petroleum Association, 17th Annual Convention, Jakarta, 275-300.

Wilson, M.E.J. and Bosence, D.W.J. 1996. The Tertiary Evolution of South Sulawesi: A Record in Redeposited Carbonates of the Tonasa Limestone Formation. In: Hall, R. \& Blundell, D.J. (eds.), Tectonic evolution of SE Asia. Geological Society of London, Special Publication 106, 365-389.

Xu, C. 2010. Porosity partitioning and permeability quantification in vuggy carbonates, Permian Basin, West Texas, U.S.A. In: Pöppelreiter, M., García-Carballido, C. and Kraaijveld, M. (eds). Dipmeter and borehole image log technology. AAPG Memoir 92, 309-319. 



\section{Figures and tables}

Figure 1) Location of the Elk-Antelope gas fields in Papua New Guinea, and their tectonic context.

Figure 2) Plan-view, top-carbonate map of the Elk and Antelope Fields shown in time (TWT two way time: from seismic). Carbonates in the Elk wells are topographically high due to thrusting, but were deposited in deeper water than those in the Antelope wells.

Figure 3) Elk-1 well: Downhole variations in FMI facies, FMI composite facies zones and inferred depositional environments plotted against FMI image, gamma and FEQL lithology logs. As noted in the text the Photoelectric Factor tool was not run in the wireline suite for the FEQL analysis of Elk-1 and dolomites are therefore not shown in the FEQL lithology column (see footnote 1 in text).

Figure 4) Elk-2 well: Downhole variations in FMI facies, FMI composite facies zones, inferred depositional environments, depositional and diagenetic features, plotted against FMI image, gamma and FEQL lithology logs.

Figure 5) Elk-1 and -2 wells - FMl facies: marl and argillaceous facies examples. (a) Header used for the FMI facies examples on this, and subsequent figures. (b) Example of marl FMI facies from Elk-1 well displaying mainly thin bedding. (c) Elk-2-2607.4 m - Photomicrograph of planktonic foraminifera mud/wackestone or marl equivalent to marl FMI facies. (d) Example of argillaceous laminated-thinly bedded limestone FMI facies from Elk-2 well displaying thin resistive beds and conductive laminations. The laminations appear much smoother, and sometimes fainter, than seen in the laminated-thinly bedded limestone. (e) Elk-1-1686 m - Photomicrograph of cutting sample equivalent to argillaceous laminatedthinly bedded limestone facies. (f) Elk-2-2658.1 m - Photomicrograph of planktonic foraminifera wacke/packstone showing irregular bed parallel dissolution seams developed along burrows equivalent to argillaceous laminated-thinly bedded limestone FMl facies. (g) Elk-2-2659.5 m - Photomicrograph of planktonic foraminifera wacke/packstone interbedded 
with predominantly silicicified planktonic foraminifera bioclastic packstone equivalent to argillaceous laminated-thinly bedded limestone FMI facies.

Figure 6) Elk-1 and -2 wells - FMI facies: laminated-, nodular-, medium-thickly bedded and mottled/altered facies examples. (a) Example of laminated-thinly bedded limestone FMI facies from Elk-2 well, displaying mainly laminations. (b) Elk-2-2709.89 m - Planktonic foraminifera bioclastic packstone including well-preserved planktonic foraminifera and fragmented bioclasts (including larger benthic foraminifera, coralline algae and bryozoa). Mechanical and chemical compaction features present. (c) Example of very thinly interbedded nodular limestone and argillaceous limestone FMI facies from Elk-1 well. (d) Elk1-1671 $\mathrm{m}$ - Range of cuttings including planktonic foraminifera bioclastic packstone and altered coral fragments equivalent to nodular and argillaceous laminated-thinly bedded limestone FMI facies. (e) Example of medium-thickly bedded limestone FMI facies from Elk-2 well. (f) Elk-2-2416 m - Photomicrograph of planktonic foraminifera bioclastic packstone equivalent to medium-thickly bedded limestone FMI facies. (g) Example of thinly mottled/bioturbated limestone FMI facies from Elk-1 well. The meshwork appearance is due to a combination of intense fracturing in addition to possible alteration.

Figure 7) Elk-1 and -2 wells - FMI facies: limestone conglomerate/breccia facies examples. (a) Example of fine-medium limestone conglomerate/breccia FMI facies from Elk-2 well (centre) with laminated-, and medium-thinly bedded limestone above and below, respectively. Fine-medium limestone conglomerate/breccia appears to fine upwards and has lamination towards the top of the unit. (b) Elk-2-2710.6 m - Photomicrograph of planktonic foraminifera bioclastic packstone (equivalent to medium limestone conglomerate/breccia FMI facies) overlying planktonic foraminifera packstone (equivalent to laminated-thinly bedded limestone FMI facies). An irregular dissolution seam closely follows the boundary between the two facies. (c) Analogue to the fine-medium limestone conglomerate/breccia imaged in (a): field photograph of calciturbidite from the Tonasa Limestone of South Sulawesi showing upwards fining and lamination towards the top of the 
unit (from Wilson and Bosence, 1996). (d) Elk-2-2813.4 m - Photomicrograph of coral, larger benthic foraminifera and carbonate lithoclast (includes planktonic foraminifera and bioclastic wacke/packstone clasts) rudstone/breccia, with clasts predominantly of pebble grade, equivalent to fine-medium limestone conglomerate/breccia FMI facies. (e) Example of coarse limestone conglomerate/breccia FMI facies from Elk-2 well, showing mainly cobble grade clasts. (f) Elk-2-2756 m - Photomicrograph of altered planktonic foraminifera pack/floatstone with coral fragments equivalent to coarse limestone conglomerate/breccia FMI facies. (g) Elk-2-2756.4 m - Photomicrograph of dolomite between clasts or in fractures in partially dolomitised bioturbated planktonic foraminifera wackestone and planktonic and larger benthic foraminifera bioclastic wacke/packstone/breccia equivalent to coarse limestone conglomerate/breccia FMI facies (h) Example of the dolomitised/highly altered coarse limestone conglomerate/breccia FMI facies from Elk-2 well.

Figure 8) Antelope-1 well: Downhole variations in FMI facies, inferred depositional environments, depositional and diagenetic features, together with representative photomicrographs plotted against FMI image, gamma and FEQL lithology logs.

Figure 9) Antelope-2 well: Downhole variations in FMl facies, inferred depositional environments, depositional and diagenetic features, plotted against FMI image, gamma and FEQL lithology logs.

Figure 10) Antelope-2 well - FMI facies: vuggy mottled limestone conglomerate/boundstone facies examples. (a) Example of vuggy mottled limestone conglomerate/boundstone FMI facies. (b \& c) Examples of vuggy mottled limestone conglomerate/boundstone FMl facies images compared to fullbore core. Note vugs, some after dissolved coral, coralline algal lamination (upper b) and rhodolith (lower c). (d \& e) $1837.34 \mathrm{~m}$ - thin section photomicrographs of coral bioclastic float/rud/packstone with fractures and vugs enhanced by dissolution. Close-up (e) shows vugs partially infilled with non-ferroan blocky calcite crystals and then by siliciclastics and dolomite crystal silt. (f) $1859.83 \mathrm{~m}$ - thin section 
photomicrograph showing bioclastic pack/grainstone with finer material concentrated along central possible burrow or seam, ( $g$ \& h) 1859.40 and $1861.40 \mathrm{~m}$ - core photographs showing dissolution seams with dark insoluble material and some laminar coralline algae (white) around recrystallised corals and within recrystallised bioclastic matrix, (i) $1869.43 \mathrm{~m}-$ thin section photomicrograph showing coral (centre) affected by early dissolution and compaction, encrusted by coralline algae in a cemented bioclastic grainstone matrix. (j) $1879.03 \mathrm{~m}$ - thin section photomicrograph showing recrystallised coral encrusted by coralline algae in a cemented bioclastic grainstone matrix. Stylolite in lower field of view. (k) $1836.45 \mathrm{~m}$ - thin section photomicrographs of recrystallised coral with micritic infill of original chambers, followed by dissolution and blocky non-ferroan calcite crystal precipitation. (I) $1862.55 \mathrm{~m}$ - thin section photomicrograph of bioclastic pack/grainstone affected by dissolution of aragonite (coral) followed by cementation (blocky non-ferroan calcite) and compaction.

Figure 11) Antelope wells - FMl facies: low-, moderate-, and high-conductivity vuggy dolomite conglomerate/boundstone facies examples. (a) Example of high-conductivity vuggy dolomite FMI facies from pervasively dolomitised upper imaged interval of Antelope-1 showing gas smearing. (b) Example of low-conductivity vuggy dolomite FMl facies from partially dolomitised interval in Antelope-1 showing large vugs. (c \& d) Examples of moderate-conductivity vuggy dolomite FMI facies from pervasively dolomitised middle interval in Antelope-2. The distinctive conductive layer in the centre of image ' $d$ ' was interpreted as possible clay or a dissolution seam. (e) Borabi-1-4623 ft core photograph: Dolomitised coral bioclastic bound/rudstone - analogue for Antelope dolomitised facies. (f-j) Thin section photomicrograph images of rotary sidewall core samples. (f) Antelope-1-1868 m - Dolomitised coral and mollusc bioclastic pack/floatstone. Dolomite has replaced micrite matrix and is present as a cement partially infilling moulds after leaching of aragonitic coral and mollusc fragments. (g) Antelope-1-1772 m - Dolomitised coral fragment. Micritic infill of coral has been dolomitised, then clear dolomite crystals partially infill biomouldic porosity 
after leached-out coral followed by precipitation of large poikilotopic calcite crystals. (h). Antelope-2-1964 m - Possible karsted dolomitised mollusc bioclastic pack/floatstone with dark micritic filled 'pipe' through centre of sample. Calcite cements occlude porosity after dolomitisation and partially infill biomoldic voids after molluscs (I) Antelope-2-2115 m Dolomitised bioclastic grainstone with moderate dolomite cement lined intergranular porosity. However, many of the calcitic bioclasts have been dolomitised (rather than dissolved) and late calcite cements occlude porosity after dolomitisation. (j) Antelope-2-2117 $m$ - Dolomitised coral retaining excellent intragranular and some moldic porosity although much of the original coral skeleton has been replaced by dolomite. Pores are lined by dolomite cements.

Figure 12) Antelope wells - FMl facies: vuggy limestone conglomerate/boundstone facies examples. (a \& b) Examples of vuggy limestone conglomerate/boundstone FMI facies from Antelope-2. (c-h) Thin section photomicrographs. (c) Antelope-1-1938.8 m - Highly altered, fractured and dissolution affected carbonate lithic and/or coral (may be subaerial exposure related). Infill of cavities by clay-size carbonate/siliciclastics \& dolomite. (d) Antelope-1$1947.4 \mathrm{~m}$ - Coralline algal bioclastic grain/rudstone. (e) Antelope-1-1956 m Coral/lithoclastic floatstone/breccia with multiple dolomite cements rimming pore space before precipitation of poikilotopic calcite crystals. (f) Antelope-2-2184.1 m - Recrystallised coral with dolomitised micritic cavity infill (layered dolomitised micrite infill may be shelter or possible karst infill) (g) Antelope-2-2189.36 m - Dolomitised bioclastic wacke/pack/floatstone with fabric replacive dolomite after micrite. Secondary porosity after dissolution of a coral fragment is partially occluded by dolomite cements. (h) Antelope-2-2184.45 m - Partially dolomitised bioclastic packstone with dolomite cements (colourless) infilling pores, some after dissolution of molluscs.

Figure 13) Antelope-2 well - Examples of vuggy limestone conglomerate (a) and finegrained thinly bedded limestone (b) FMl facies from the lower imaged section of Antelope-2. 
(c \& d) Antelope-2 examples of thin sections corresponding to fine-grained thinly bedded limestone FMI facies. (c) Antelope-2-2240 m - Mollusc bioclastic grainstone with calcite cements occluding porosity. (d) Antelope-2-2363 m - Imperforate foraminifera bioclastic grainstone with drusy to blocky cements infilling most porosity (some after leached corals). (e \& f) Antelope-2 examples of thin sections corresponding to vuggy limestone conglomerate FMI facies. (e) Antelope-2-2437 m - Cemented recrystallised coral rudstone with isopachous and blocky cements infilling pores. (f) Antelope-2-2388 m - Cemented recrystallised coral with isopachous and blocky cements infilling most porosity (after leached corals). (g) Antelope-2-2289 m - Limestone breccia with dolomitised matrix/cement infill - breccia may be karst related. (h) Antelope-2-2304 m - Close-up view of glaebular/alveolar texture in coral bioclastic pack/rudstone.

Figure 14) Antelope-1 well - (a) Example of limestone conglomerate/boundstone (lower part of image) and fine mottled limestone (upper part of image) from below partially dolomitised zone in Antelope-1. (b) FMI example of one of the 'cycle' boundaries (middle of image) in the middle imaged portion of Antelope-1. Lower part of image is a limestone conglomerate passing upwards into a conglomerate/boundstone FMl texture below the unconformable contact. Above the unconformity a fine, medium bedded limestone passes upwards into a massive-medium bedded clastic limestone FMI facies. (c) Antelope-1-1983 m - Limestone lithoclastic breccia with dolomitised isopachous cements. (d) Antelope-1-2076 m Imperforate foraminifera (and mollusc) bioclastic grain/packstone. (e) Antelope-1- $2004.5 \mathrm{~m}$ - Reddened bioclastic grain/packstone (upper part of image) with alteration and glaebular texture in a dissolution cavity (lower part of image). Reddening, dissolution and the glaebular structure are all probably associated with karstification. (f) Antelope-1- 2228 m - Halimeda, coral (\& larger benthic foraminifera) bioclastic rud/grainstone with isopachous cements.

Figure 15) Antelope-1 well lower imaged section - (a) Example of limestone conglomerate/breccia (highlighted by blue boxes) interdigitated with fine, thinly bedded 
limestone FMI facies. (b). Antelope-1- 2238 m - Larger benthic foraminifera, (coralline algal \& echinoderm) pack/grainstone corresponding to limestone conglomerate/breccia FMI facies. (c). Antelope-1-2402 m - Carbonate lithoclastic and larger benthic foraminifera bioclastic floatstone corresponding to limestone conglomerate/breccia FMI facies. (d) Antelope-1- $2323.8 \mathrm{~m}$ - Planktonic foraminifera (larger benthic foraminifera and echinoderm) pack/wackestone corresponding to fine, thinly bedded limestone FMI facies. (e) Antelope-1$2290.5 \mathrm{~m}$ - Coral \& lithoclastic rudstone/breccia corresponding to limestone conglomerate/boundstone FMl facies.

Figure 16) Summary diagram showing depositional and diagenetic observations and inferences possible from a combined borehole (FMI) image analysis and petrography study together with implications for the characterisation, understanding and prediction of reservoir quality.

Table 1) Characteristics of the FMI facies from the Elk-1 and -2 wells, and their petrographic features.

Table 2) Table of composite FMI facies zones, their inferred characteristics and environment of deposition from Elk-1 and Elk-2 wells.

Table 3) Characteristics of the FMI facies from the Antelope- 1 and -2 wells, and their petrographic features.

Appendix 1) Table sample locations, their lithologies from petrology, and the FMl facies defined from the image logs at the depth the sample was taken. 



\begin{tabular}{|l|l|l|l|l|}
\hline Well & $\begin{array}{l}\text { Sample } \\
\text { type }\end{array}$ & $\begin{array}{l}\text { Depth } \\
(\mathrm{m})\end{array}$ & Lithology - MW & FMI facies - DL \\
\hline Elk-1 & Cuttings & 1671 & $\begin{array}{l}\text { Planktonic foraminifera } \\
\text { (bioclastic/coral) } \\
\text { Wacke/Packstone - richer in } \\
\text { coral and other bioclastic-rich } \\
\text { cuttings than other two samples } \\
\text { studied }\end{array}$ & $\begin{array}{l}\text { Argillaceous laminated-thinly bedded } \\
\text { Limestone facies, but just below } \\
\text { (<1670 m) Nodular Lm - Argillaceous } \\
\text { Lm facies }\end{array}$ \\
\hline & Cuttings & 1674 & $\begin{array}{l}\text { Planktonic foraminifera } \\
\text { (bioclastic/coral) } \\
\text { Wacke/Packstone }\end{array}$ & $\begin{array}{l}\text { Argillaceous laminated-thinly bedded } \\
\text { Limestone }\end{array}$ \\
\hline & Cuttings & 1680 & PF (bioclastic/coral) W/P & $\begin{array}{l}\text { Argillaceous laminated-thinly bedded } \\
\text { Limestone }\end{array}$ \\
\hline & Cuttings & 1683 & $\begin{array}{l}\text { Argillaceous laminated-thinly bedded } \\
\text { Limestone }\end{array}$ \\
\hline & Cuttings & 1686 & $\begin{array}{l}\text { Planktonic foraminifera } \\
\text { (bioclastic/coral) } \\
\text { Wacke/Packstone }\end{array}$ & $\begin{array}{l}\text { Argillaceous laminated-thinly bedded } \\
\text { Limestone }\end{array}$ \\
\hline & Cuttings & 1689 & PF (bioclastic) W/P & $\begin{array}{l}\text { Argillaceous laminated-thinly bedded } \\
\text { Limestone within 1 m of Nodular } \\
\text { Limestone \& Argillaceous Limestone }\end{array}$ \\
\hline
\end{tabular}

\begin{tabular}{|c|c|c|c|c|}
\hline Well & $\begin{array}{l}\text { Sample } \\
\text { type }\end{array}$ & $\begin{array}{l}\text { Depth } \\
\text { (m) }\end{array}$ & Lithology - MW & FMI facies - DL \\
\hline \multirow[t]{13}{*}{ Elk-2 } & SWC & 2355.80 & $\begin{array}{l}\text { PF (bioturbated) } \\
\text { wacke/packstone with } \\
\text { dissolution seam }\end{array}$ & $\begin{array}{l}\text { Argillaceous laminated thinly bedded } \\
\text { Limestone }\end{array}$ \\
\hline & SWC & 2409.00 & Coral bioclastic grainstone & Fine limestone conglomerate/breccia \\
\hline & SWC & 2416.00 & $\begin{array}{l}\text { Bioturbated PF bioclastic } \\
\text { packstone with dissolution seam }\end{array}$ & Medium thickly bedded limestone \\
\hline & SWC & 2607.40 & PF wacke/mudstone or marl & Marl \\
\hline & PfC? & 2658.10 & $\begin{array}{l}\text { Bioturbated PF } \\
\text { wacke/packstone with abundant } \\
\text { dissolution seam }\end{array}$ & $\begin{array}{l}\text { Argillaceous laminated thinly bedded } \\
\text { Limestone }\end{array}$ \\
\hline & PfC? & 2659.50 & $\begin{array}{l}\text { PF wacke/packstone } \\
\text { interbedded with partially } \\
\text { silicified PF bioclastic packstone }\end{array}$ & $\begin{array}{l}\text { Argillaceous laminated thinly bedded } \\
\text { Limestone }\end{array}$ \\
\hline & $\mathrm{PfC} ?$ & 2709.40 & $\begin{array}{l}\text { PF \& LBF bioclastic packstone } \\
\text { with well preserved shallow } \\
\text { bioclasts }\end{array}$ & $\begin{array}{l}\text { Medium limestone } \\
\text { conglomerate/breccia }\end{array}$ \\
\hline & PfC? & 2709.82 & $\begin{array}{l}\text { PF \& LBF bioclastic packstone } \\
\text { with well preserved shallow } \\
\text { bioclasts }\end{array}$ & $\begin{array}{l}\text { Medium limestone } \\
\text { conglomerate/breccias to laminated } \\
\text { thinly bedded limestone }\end{array}$ \\
\hline & PfC? & 2709.89 & $\begin{array}{l}\text { Larger Benthic \& planktonic } \\
\text { foraminifera bioclastic packstone }\end{array}$ & $\begin{array}{l}\text { Laminated thinly bedded limestone } \\
\text { and fine limestone } \\
\text { conglomerate/breccia }\end{array}$ \\
\hline & PfC? & 2710.35 & $\begin{array}{l}\text { LBF (coral) \& PF bioclastic } \\
\text { packstone }\end{array}$ & $\begin{array}{l}\text { Medium limestone } \\
\text { conglomerate/breccia }\end{array}$ \\
\hline & $\mathrm{PfC} ?$ & 2710.60 & $\begin{array}{l}\text { PF packstone interbedded with } \\
\text { PF bioclastic packstone }\end{array}$ & Laminated thinly bedded limestone \\
\hline & SWC & 2731.60 & $\begin{array}{l}\text { Coral, LBF, ?carb lithoclastic } \\
\text { pack/rudstone/breccia }\end{array}$ & $\begin{array}{l}\text { Medium limestone } \\
\text { conglomerate/breccia }\end{array}$ \\
\hline & SWC & 2749.00 & $\begin{array}{l}\text { Fine Compacted partially } \\
\text { dolomitised PF (bioclastic) } \\
\text { packstone and coarse } \\
\text { undolomitised (uncompacted) } \\
\text { PF \& LBF bioclastic packstone }\end{array}$ & Laminated thinly bedded limestone \\
\hline
\end{tabular}




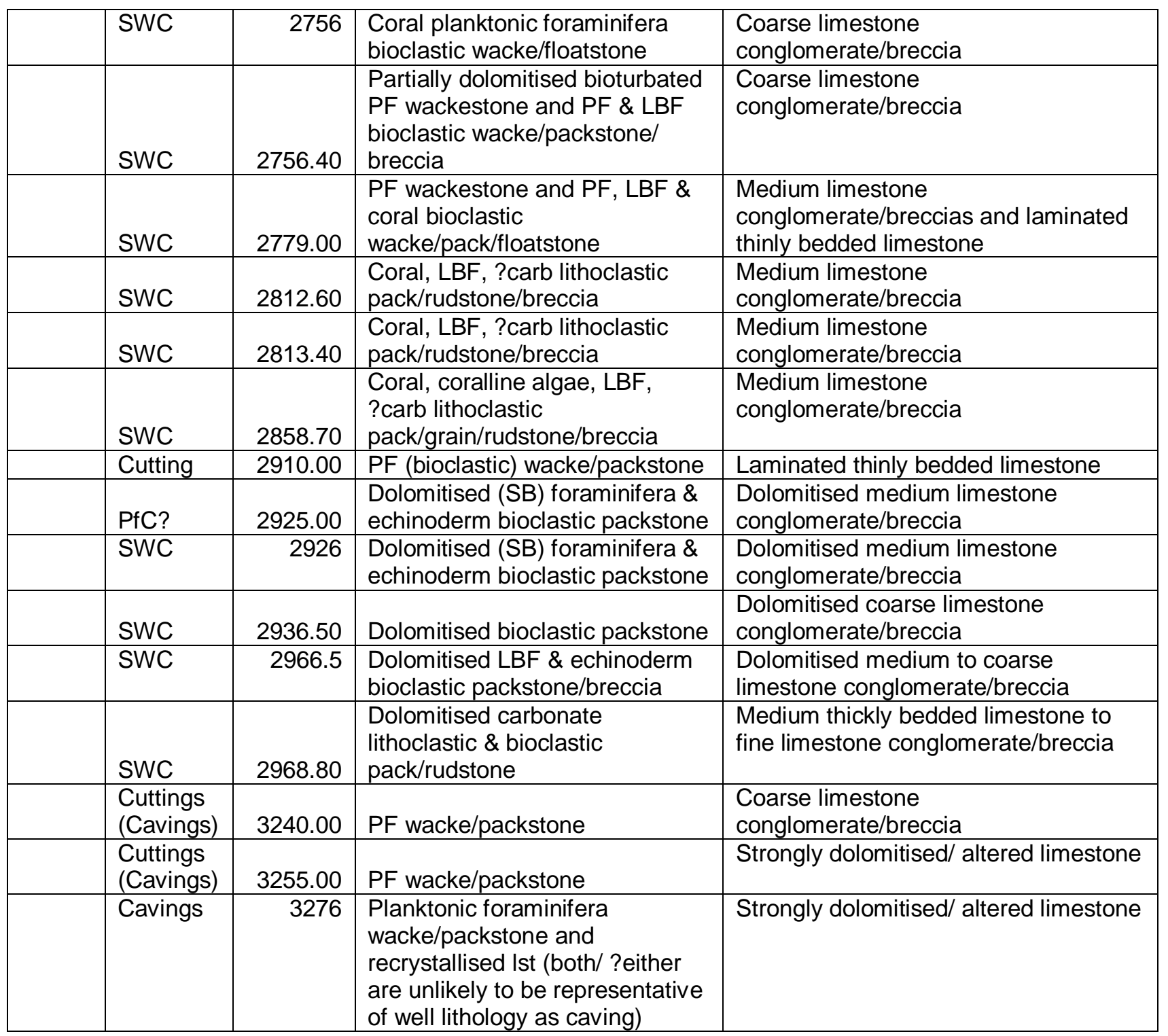

\begin{tabular}{|l|l|l|l|l|}
\hline Well & $\begin{array}{l}\text { Sample } \\
\text { type }\end{array}$ & $\begin{array}{l}\text { Depth } \\
\text { (m) }\end{array}$ & Lithology - MW & FMl facies - DL \& MW \\
\hline Ant-1 & SWC & 1748.0 & $\begin{array}{l}\text { Dolomitized Coral bioclastic } \\
\text { ?rud/floatstone }\end{array}$ & $\begin{array}{l}\text { Moderate conductivity vuggy dolomite } \\
\text { conglomerate/ boundstone }\end{array}$ \\
\hline & SWC & 1753.0 & Dolostone & $\begin{array}{l}\text { Moderate conductivity vuggy dolomite } \\
\text { conglomerate/ boundstone }\end{array}$ \\
\hline & SWC & 1761.8 & $\begin{array}{l}\text { Dolomitized Coral bioclastic } \\
\text { float/pack/grainstone }\end{array}$ & $\begin{array}{l}\text { Moderate conductivity vuggy dolomite } \\
\text { conglomerate/ boundstone }\end{array}$ \\
\hline & SWC & 1766.4 & $\begin{array}{l}\text { Dolomitized Coral (\& CA) } \\
\text { bioclastic float/pack/grainstone }\end{array}$ & $\begin{array}{l}\text { Moderate conductivity vuggy dolomite } \\
\text { conglomerate/ boundstone }\end{array}$ \\
\hline & SWC & 1770.5 & $\begin{array}{l}\text { Dolomitised coralline algae } \\
\text { bioclastic ?packstone }\end{array}$ & $\begin{array}{l}\text { Moderate conductivity vuggy dolomite } \\
\text { conglomerate/ boundstone }\end{array}$ \\
\hline & SWC & 1772.0 & Dolomitized coral & $\begin{array}{l}\text { Moderate conductivity vuggy dolomite } \\
\text { conglomerate/ boundstone }\end{array}$ \\
\hline & SWC & 1780.0 & $\begin{array}{l}\text { Dolomitized Coral bioclastic } \\
\text { float/pack/grainstone }\end{array}$ & $\begin{array}{l}\text { High conductivity vuggy dolomite } \\
\text { conglomerate/ boundstone }\end{array}$ \\
\hline & SWC & 1786.0 & $\begin{array}{l}\text { Dolomitized Coral \& CA } \\
\text { bioclastic float/packstone }\end{array}$ & $\begin{array}{l}\text { Moderate conductivity vuggy dolomite } \\
\text { conglomerate/ boundstone }\end{array}$ \\
\hline & SWC & 1788.8 & $\begin{array}{l}\text { Dolomitized Halimeda bioclastic } \\
\text { grain/packstone }\end{array}$ & $\begin{array}{l}\text { Moderate conductivity vuggy dolomite } \\
\text { conglomerate/ boundstone }\end{array}$ \\
\hline & SWC & 1793.8 & Dolomitized coralline algae \& & High conductivity vuggy dolomite \\
\hline
\end{tabular}




\begin{tabular}{|c|c|c|c|}
\hline & & Halimeda) bioclastic packstone & conglomerate/ boundstone \\
\hline SWC & 1796.0 & $\begin{array}{l}\text { Reddened coral ( } \& \\
\text { mollusc/Halimeda) bioclastic } \\
\text { packstone }\end{array}$ & $\begin{array}{l}\text { High conductivity vuggy dolomite } \\
\text { conglomerate/ boundstone }\end{array}$ \\
\hline SWC & 1799.5 & $\begin{array}{l}\text { Dolomitised bioclastic } \\
\text { grainstone }\end{array}$ & $\begin{array}{l}\text { High conductivity vuggy dolomite } \\
\text { conglomerate/ boundstone }\end{array}$ \\
\hline SWC & 1800.0 & $\begin{array}{l}\text { Dolomitised \& Reddened coral } \\
\text { bioclastic float/packstone }\end{array}$ & $\begin{array}{l}\text { High conductivity vuggy dolomite } \\
\text { conglomerate/ boundstone }\end{array}$ \\
\hline SWC & 1800.5 & $\begin{array}{l}\text { Dolomitised bioclastic } \\
\text { grain/packstone }\end{array}$ & $\begin{array}{l}\text { High conductivity vuggy dolomite } \\
\text { conglomerate/ boundstone }\end{array}$ \\
\hline SWC & 1804.0 & $\begin{array}{l}\text { Dolomitized Halimeda bioclastic } \\
\text { wacke/packstone }\end{array}$ & $\begin{array}{l}\text { High conductivity vuggy dolomite } \\
\text { conglomerate/ boundstone }\end{array}$ \\
\hline SWC & 1808.4 & $\begin{array}{l}\text { Dolomitised bioclastic } \\
\text { grain/packstone }\end{array}$ & $\begin{array}{l}\text { High conductivity vuggy dolomite } \\
\text { conglomerate/ boundstone }\end{array}$ \\
\hline SWC & 1815.0 & $\begin{array}{l}\text { Dolomitized Coral bioclastic } \\
\text { rud/grainstone }\end{array}$ & $\begin{array}{l}\text { High conductivity vuggy dolomite } \\
\text { conglomerate/ boundstone }\end{array}$ \\
\hline SWC & 1820.0 & $\begin{array}{l}\text { Dolomitized Mollusc bioclastic } \\
\text { packstone }\end{array}$ & $\begin{array}{l}\text { High conductivity vuggy dolomite } \\
\text { conglomerate/ boundstone }\end{array}$ \\
\hline SWC & 1820.6 & $\begin{array}{l}\text { Dolomitized (Mollusc) bioclastic } \\
\text { packstone }\end{array}$ & $\begin{array}{l}\text { High conductivity vuggy dolomite } \\
\text { conglomerate/ boundstone }\end{array}$ \\
\hline SWC & 1823.0 & $\begin{array}{l}\text { Dolomitized Coral bioclastic } \\
\text { rud/grainstone }\end{array}$ & $\begin{array}{l}\text { High conductivity vuggy dolomite } \\
\text { conglomerate/ boundstone }\end{array}$ \\
\hline SWC & 1827.0 & Dolomitized coral & $\begin{array}{l}\text { Moderate conductivity vuggy dolomite } \\
\text { conglomerate/ boundstone }\end{array}$ \\
\hline SWC & 1833.0 & $\begin{array}{l}\text { Dolomitised \& Reddened coral } \\
\text { bioclastic float/packstone }\end{array}$ & $\begin{array}{l}\text { Moderate conductivity vuggy dolomite } \\
\text { conglomerate/ boundstone }\end{array}$ \\
\hline SWC & 1838.7 & $\begin{array}{l}\text { Dolomitised \& Reddened } \\
\text { bioclastic pack/grainstone }\end{array}$ & $\begin{array}{l}\text { Moderate conductivity vuggy dolomite } \\
\text { conglomerate/ boundstone }\end{array}$ \\
\hline SWC & 1844.2 & $\begin{array}{l}\text { Dolomitised \& Reddened coral \& } \\
\text { mollusc bioclastic packstone }\end{array}$ & $\begin{array}{l}\text { Moderate conductivity vuggy dolomite } \\
\text { conglomerate/ boundstone }\end{array}$ \\
\hline SWC & 1854.0 & $\begin{array}{l}\text { Dolomitised \& Reddened } \\
\text { bioclastic packstone }\end{array}$ & $\begin{array}{l}\text { Moderate conductivity vuggy dolomite } \\
\text { conglomerate/ boundstone }\end{array}$ \\
\hline SWC & 1858.0 & $\begin{array}{l}\text { Dolomitised ( } \& \text { Reddened) coral } \\
\& \text { mollusc bioclastic } \\
\text { pack/floatstone }\end{array}$ & $\begin{array}{l}\text { Moderate conductivity vuggy dolomite } \\
\text { conglomerate/ boundstone }\end{array}$ \\
\hline SWC & 1864.6 & $\begin{array}{l}\text { Dolomitised mollusc bioclastic } \\
\text { packstone }\end{array}$ & $\begin{array}{l}\text { Moderate conductivity vuggy dolomite } \\
\text { conglomerate/ boundstone }\end{array}$ \\
\hline SWC & 1868.0 & $\begin{array}{l}\text { Dolomitised coral \& mollusc } \\
\text { bioclastic pack/floatstone }\end{array}$ & $\begin{array}{l}\text { Moderate conductivity vuggy dolomite } \\
\text { conglomerate/ boundstone }\end{array}$ \\
\hline SWC & 1873.0 & $\begin{array}{l}\text { Dolomitised bioclastic } \\
\text { pack/grainstone }\end{array}$ & $\begin{array}{l}\text { Moderate conductivity vuggy dolomite } \\
\text { conglomerate/ boundstone }\end{array}$ \\
\hline SWC & 1874.0 & $\begin{array}{l}\text { Dolomitised bioclastic } \\
\text { pack/grainstone }\end{array}$ & $\begin{array}{l}\text { Moderate conductivity vuggy dolomite } \\
\text { conglomerate/ boundstone }\end{array}$ \\
\hline SWC & 1895.6 & $\begin{array}{l}\text { Dolomitised \& Reddened coral } \\
\text { bioclastic float/packstone }\end{array}$ & $\begin{array}{l}\text { Moderate conductivity vuggy dolomite } \\
\text { conglomerate/ boundstone }\end{array}$ \\
\hline SWC & 1900.0 & $\begin{array}{l}\text { Dolomitised bioclastic (mollusc) } \\
\text { grainstone }\end{array}$ & $\begin{array}{l}\text { Moderate conductivity vuggy dolomite } \\
\text { conglomerate/ boundstone }\end{array}$ \\
\hline SWC & 1902.6 & $\begin{array}{l}\text { Dolomitised \& Reddened coral } \\
\text { bioclastic float/packstone }\end{array}$ & $\begin{array}{l}\text { Moderate conductivity vuggy dolomite } \\
\text { conglomerate/ boundstone }\end{array}$ \\
\hline SWC & 1905.6 & $\begin{array}{l}\text { Dolomitised \& Reddened coral } \\
\text { bioclastic float/packstone }\end{array}$ & $\begin{array}{l}\text { Moderate conductivity vuggy dolomite } \\
\text { conglomerate/ boundstone }\end{array}$ \\
\hline SWC & 1913.6 & $\begin{array}{l}\text { Dolomitised bioclastic } \\
\text { grainstone }\end{array}$ & $\begin{array}{l}\text { Moderate conductivity vuggy dolomite } \\
\text { conglomerate/ boundstone }\end{array}$ \\
\hline SWC & 1920.8 & Dolomitised \& Reddened coral & $\begin{array}{l}\text { Moderate conductivity vuggy dolomite } \\
\text { conglomerate/ boundstone }\end{array}$ \\
\hline SWC & 1933.2 & Dolomite crystal & $\begin{array}{l}\text { Low conductivity vuggy dolomite } \\
\text { conglomerate/ boundstone }\end{array}$ \\
\hline SWC & 1938.8 & $\begin{array}{l}\text { Recrystalised, fractured \& } \\
\text { partially dolomitised }\end{array}$ & $\begin{array}{l}\text { Low conductivity vuggy dolomite } \\
\text { conglomerate/ boundstone }\end{array}$ \\
\hline
\end{tabular}




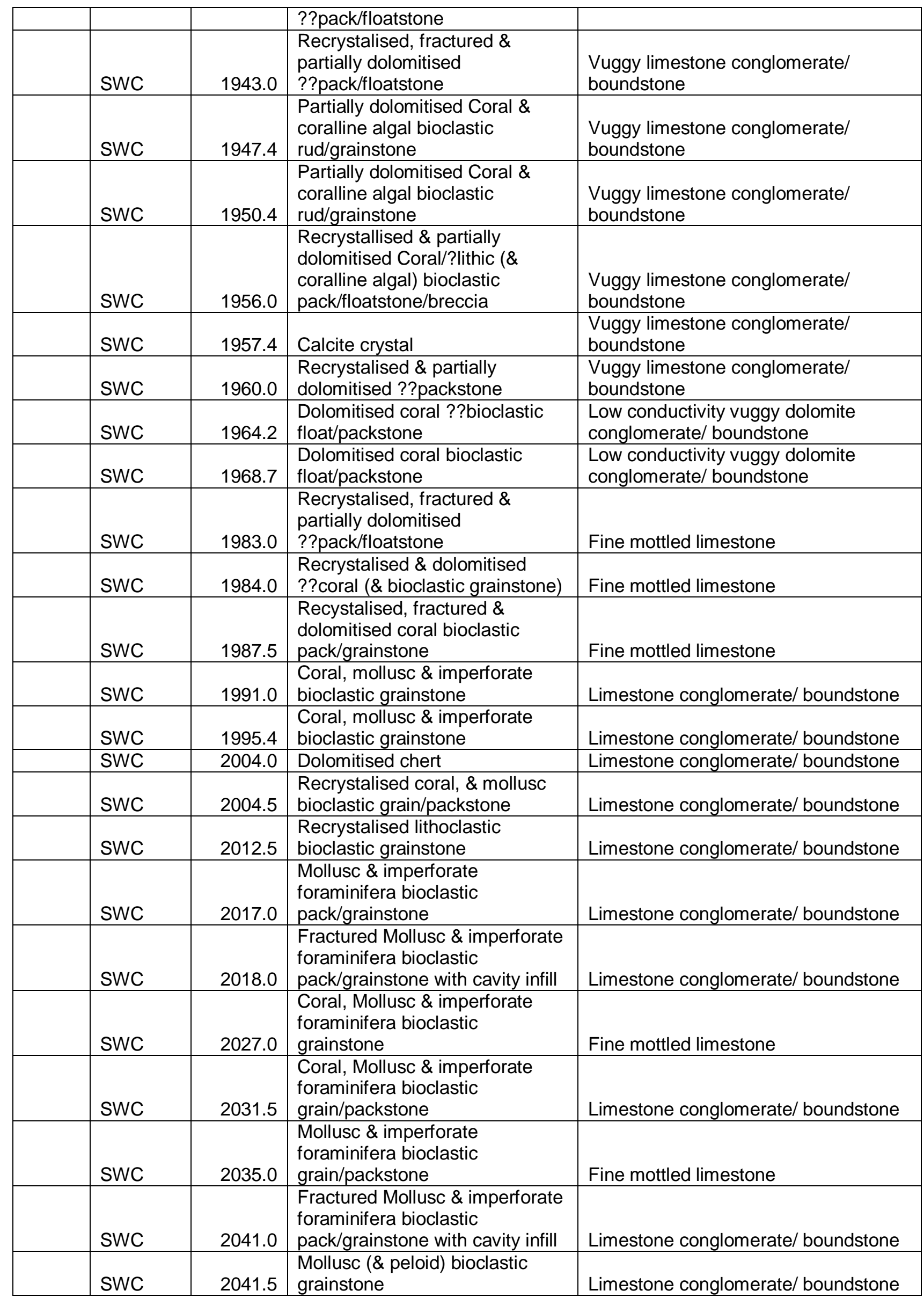




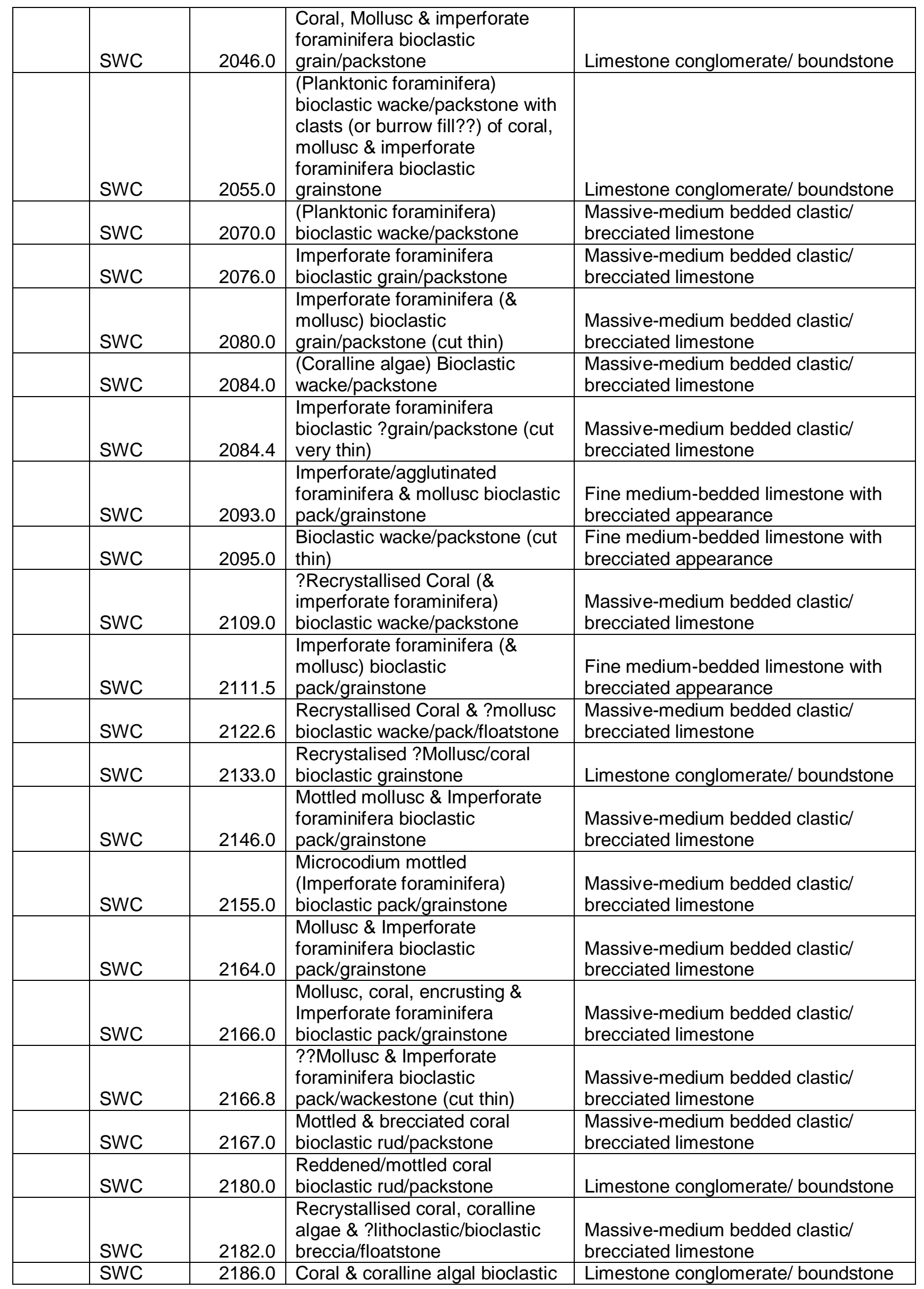




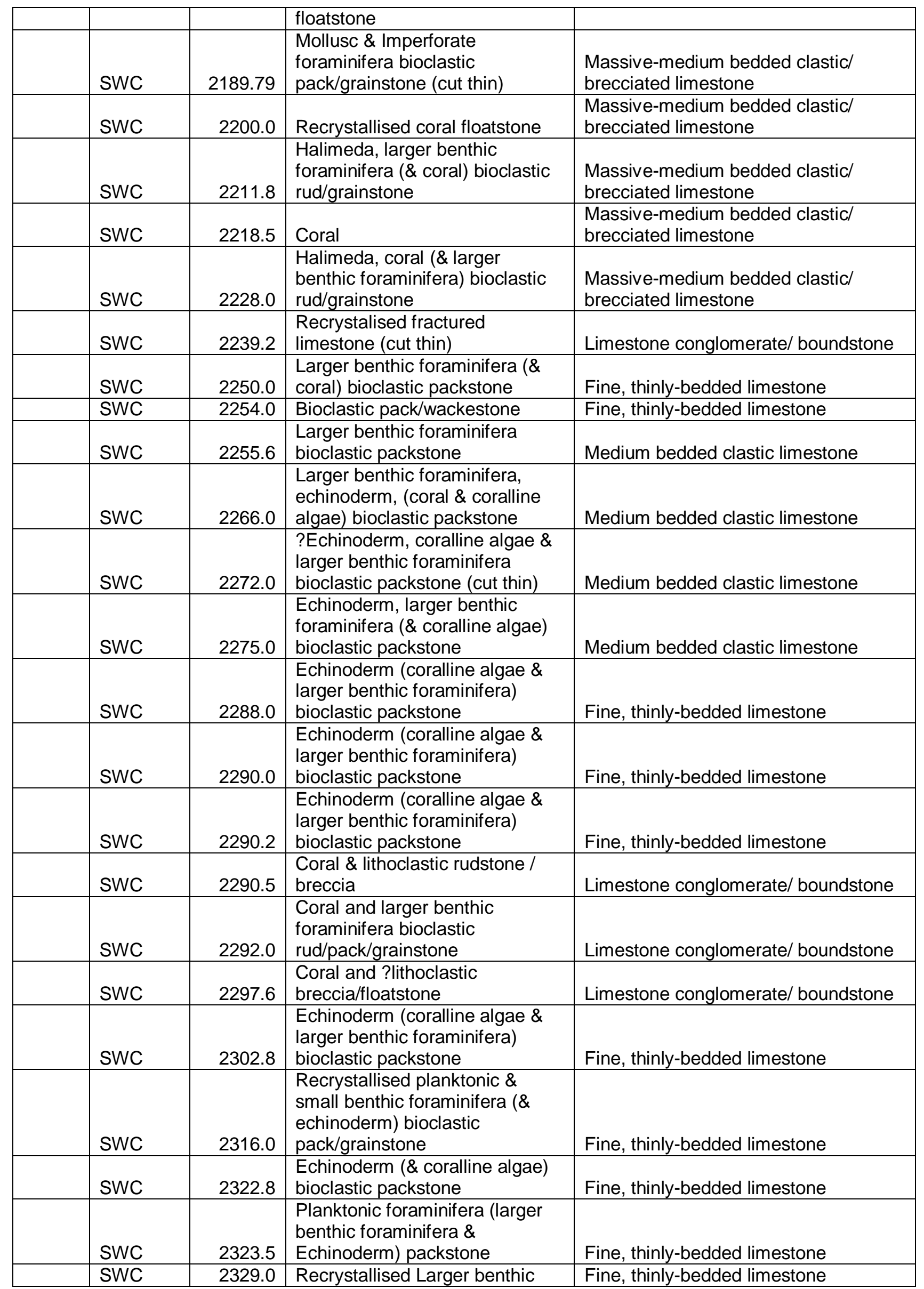




\begin{tabular}{|c|c|c|c|}
\hline & & $\begin{array}{l}\text { foraminifera ( \& Coralline algal) } \\
\text { grainstone }\end{array}$ & \\
\hline SWC & 2338.0 & $\begin{array}{l}\text { Larger benthic foraminifera, } \\
\text { (Coralline algal \& echinoderm) } \\
\text { pack/grainstone }\end{array}$ & Medium bedded clastic limestone \\
\hline SWC & 2353.0 & $\begin{array}{l}\text { Altered Larger benthic } \\
\text { foraminifera \& coral bioclastic } \\
\text { rud/?grainstone (cut very thin) }\end{array}$ & $\begin{array}{l}\text { Fine, thinly-bedded limestone } \\
\text { containing clasts }\end{array}$ \\
\hline SWC & 2372.6 & $\begin{array}{l}\text { Larger benthic foraminifera \& } \\
\text { coral bioclastic grainstone }\end{array}$ & Thickly bedded clastic limestone \\
\hline SWC & 2394.0 & $\begin{array}{l}\text { Coral bioclastic } \\
\text { rud/packgrainstone }\end{array}$ & Medium bedded clastic limestone \\
\hline SWC & 2396.0 & $\begin{array}{l}\text { Carbonate ?lithoclastic and } \\
\text { larger benthic foraminifera } \\
\text { bioclastic floatstone }\end{array}$ & Medium bedded clastic limestone \\
\hline SWC & 2401.0 & $\begin{array}{l}\text { Carbonate ?lithoclastic and } \\
\text { larger benthic foraminifera } \\
\text { bioclastic floatstone }\end{array}$ & Medium bedded clastic limestone \\
\hline SWC & 2402.0 & $\begin{array}{l}\text { Carbonate lithoclastic and larger } \\
\text { benthic foraminifera bioclastic } \\
\text { floatstone }\end{array}$ & Medium bedded clastic limestone \\
\hline SWC & 2409.0 & $\begin{array}{l}\text { Planktonic foraminifera } \\
\text { bioclastic packstone (cut very } \\
\text { thin) }\end{array}$ & Fine, thinly bedded limestone \\
\hline SWC & 2445.0 & $\begin{array}{l}\text { Larger benthic foraminifera, } \\
\text { (Coralline algal \& echinoderm) } \\
\text { pack/grainstone }\end{array}$ & Fine, thinly bedded limestone \\
\hline
\end{tabular}

\begin{tabular}{|c|c|c|c|c|}
\hline Well & $\begin{array}{l}\text { Sample } \\
\text { type }\end{array}$ & $\begin{array}{l}\text { Depth } \\
\text { (m) }\end{array}$ & Lithology - MW & FMI facies - DL \& MW \\
\hline \multirow{15}{*}{ Ant-2 } & SWC & 1832 & $\begin{array}{l}\text { Recrystallised coral bioclastic } \\
\text { float/pack/grainstone }\end{array}$ & $\begin{array}{l}\text { Vuggy Mottled Limestone } \\
\text { Conglomerate / Boundstone }\end{array}$ \\
\hline & SWC & 1834 & $\begin{array}{l}\text { Recrystallised coral bioclastic } \\
\text { pack/floatstone }\end{array}$ & $\begin{array}{l}\text { Vuggy Mottled Limestone } \\
\text { Conglomerate / Boundstone }\end{array}$ \\
\hline & FCP & 1835.24 & Algal bioclastic pack/grainstone & $\begin{array}{l}\text { Vuggy Mottled Limestone } \\
\text { Conglomerate / Boundstone }\end{array}$ \\
\hline & SWC & 1836 & Algal bioclastic grain/pacstone & $\begin{array}{l}\text { Vuggy Mottled Limestone } \\
\text { Conglomerate / Boundstone }\end{array}$ \\
\hline & FCP & 1836.45 & Recrystalised coral & $\begin{array}{l}\text { Vuggy Mottled Limestone } \\
\text { Conglomerate / Boundstone }\end{array}$ \\
\hline & FCP & 1837.34 & $\begin{array}{l}\text { Recrystalised coral bioclastic } \\
\text { rudstone }\end{array}$ & $\begin{array}{l}\text { Vuggy Mottled Limestone } \\
\text { Conglomerate / Boundstone }\end{array}$ \\
\hline & FCP & 1838.51 & $\begin{array}{l}\text { Recrystalised coral bioclastic } \\
\text { rud/float/packstone }\end{array}$ & $\begin{array}{l}\text { Vuggy Mottled Limestone } \\
\text { Conglomerate / Boundstone }\end{array}$ \\
\hline & FCP & 1840.02 & Coral bioclastic pack/grainstone & $\begin{array}{l}\text { Vuggy Mottled Limestone } \\
\text { Conglomerate / Boundstone }\end{array}$ \\
\hline & SWC & 1843 & $\begin{array}{l}\text { Recrystallised coral bioclastic } \\
\text { grain/float/rudstone }\end{array}$ & $\begin{array}{l}\text { Vuggy Mottled Limestone } \\
\text { Conglomerate / Boundstone }\end{array}$ \\
\hline & SWC & 1845 & $\begin{array}{l}\text { (Coral) Algal bioclastic } \\
\text { grain/packstone }\end{array}$ & $\begin{array}{l}\text { Vuggy Mottled Limestone } \\
\text { Conglomerate / Boundstone }\end{array}$ \\
\hline & FCP & 1846.35 & $\begin{array}{l}\text { (Coral) Algal bioclastic } \\
\text { grain/packstone }\end{array}$ & $\begin{array}{l}\text { Vuggy Mottled Limestone } \\
\text { Conglomerate / Boundstone }\end{array}$ \\
\hline & FCP & 1848.74 & Bioclastic pack/grainstone & $\begin{array}{l}\text { Vuggy Mottled Limestone } \\
\text { Conglomerate / Boundstone }\end{array}$ \\
\hline & FCP & 1849.64 & Bioclastic pack/graintone & $\begin{array}{l}\text { Vuggy Mottled Limestone } \\
\text { Conglomerate / Boundstone }\end{array}$ \\
\hline & SWC & 1850 & $\begin{array}{l}\text { Recrystallised coral bioclastic } \\
\text { grain/pack/rudstone }\end{array}$ & $\begin{array}{l}\text { Vuggy Mottled Limestone } \\
\text { Conglomerate / Boundstone }\end{array}$ \\
\hline & FCP & 1851.47 & Recrystalised coral \& mollusc & Vuggy Mottled Limestone \\
\hline
\end{tabular}




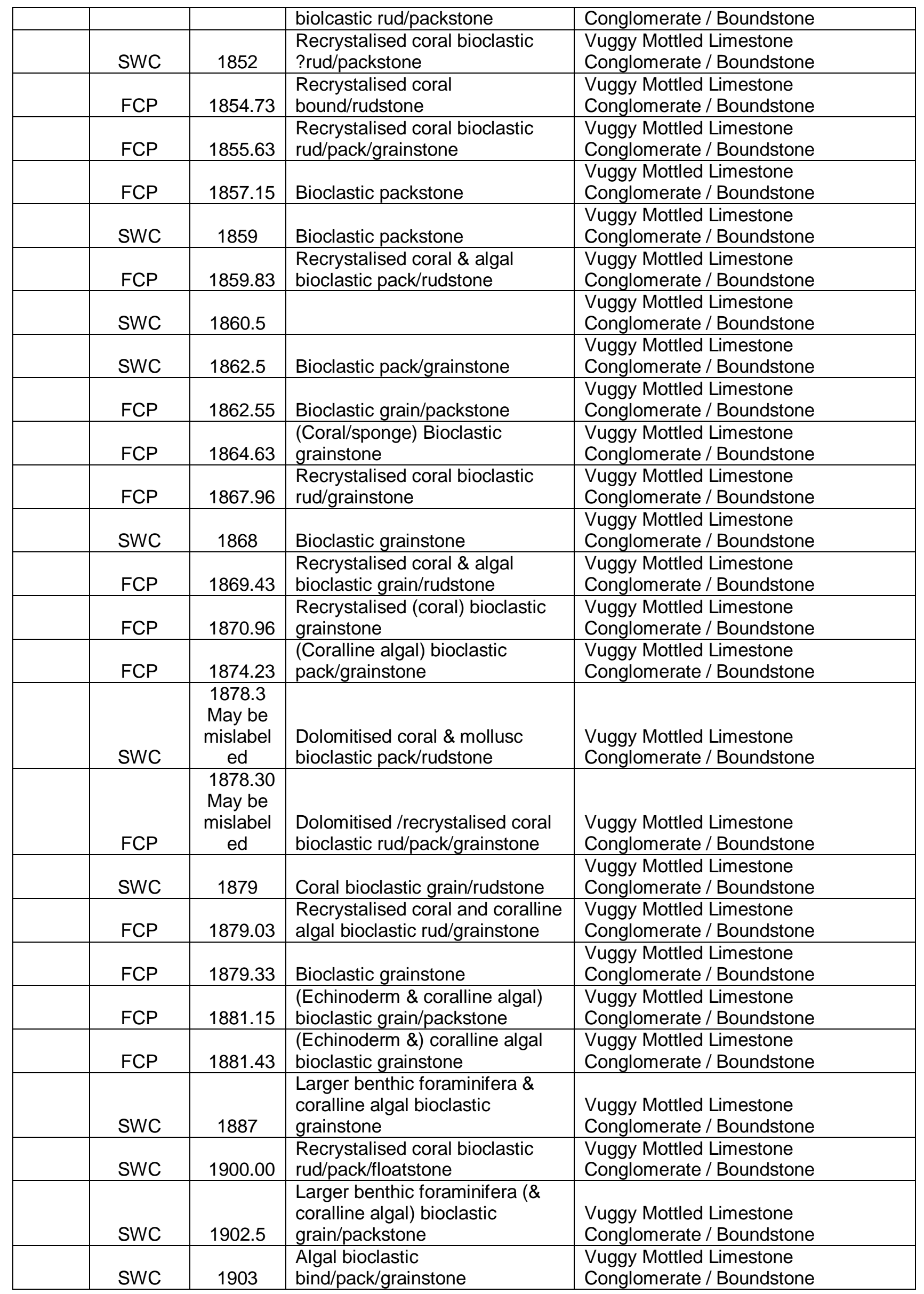




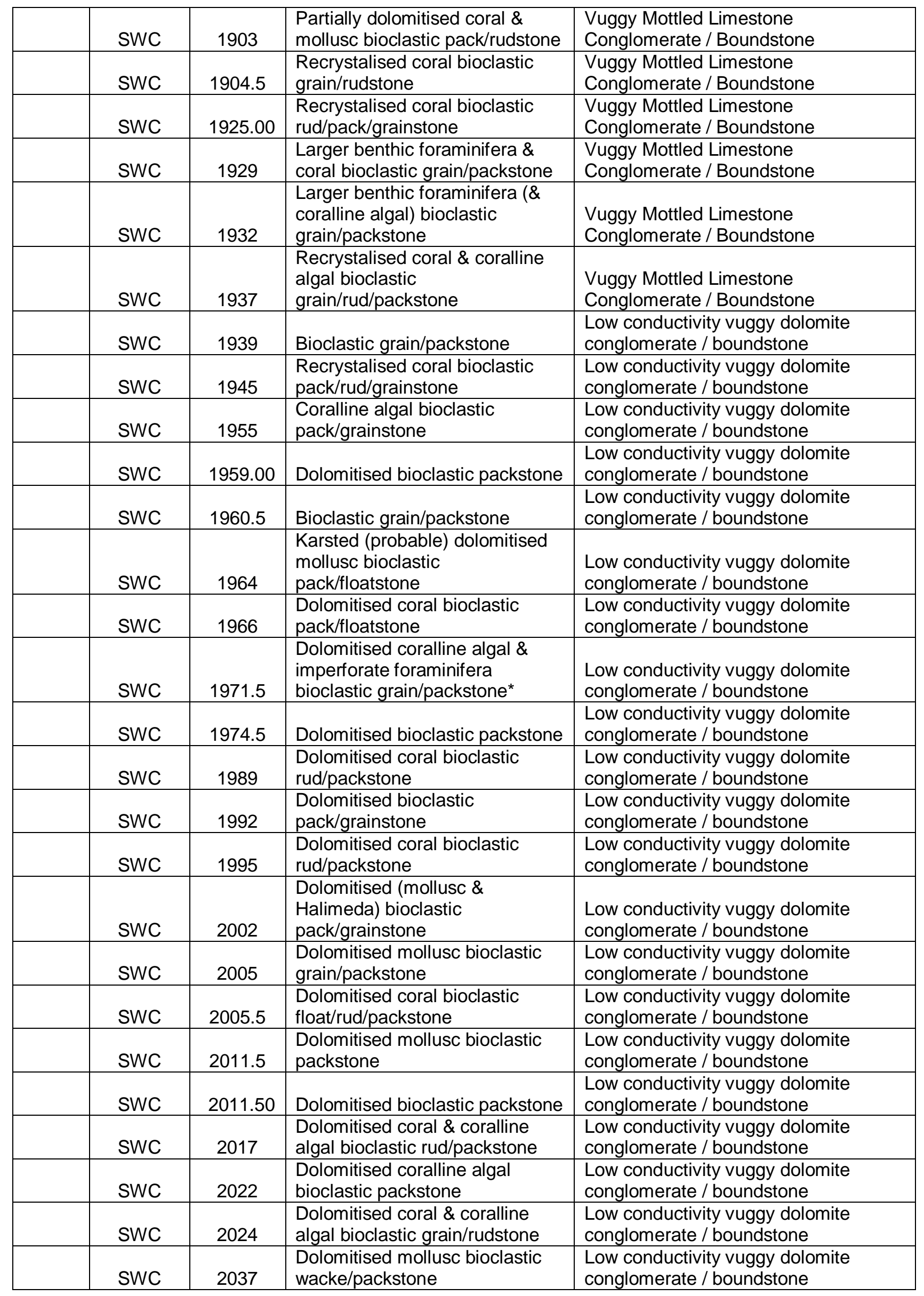




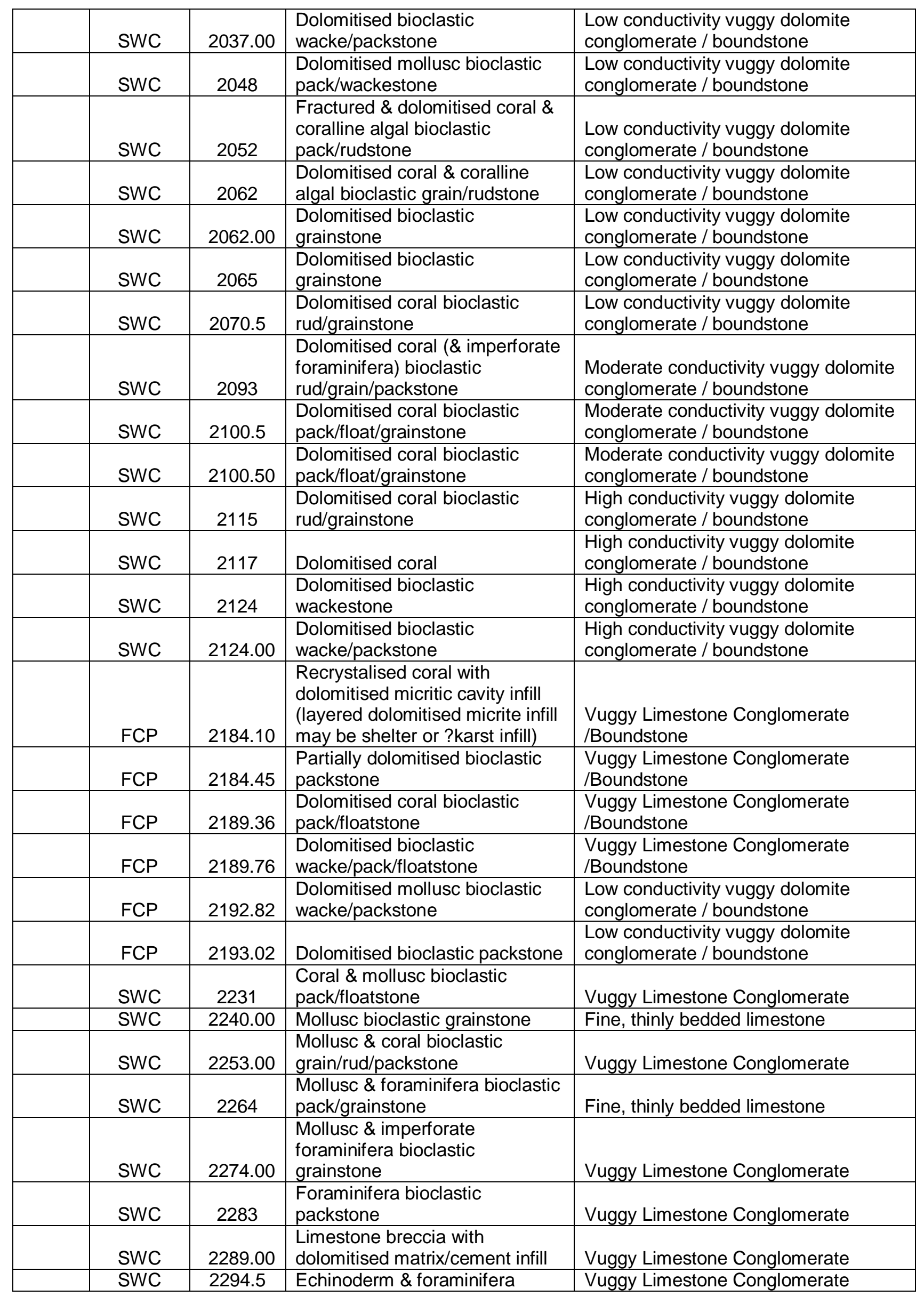




\begin{tabular}{|c|c|c|c|c|}
\hline & & & bioclastic packstone & \\
\hline & SWC & 2302.00 & Bioclastic pack/grainstone & Vuggy Limestone Conglomerate \\
\hline & SWC & 2304 & $\begin{array}{l}\text { Glaebular/alveolar coral } \\
\text { bioclastic pack/rudstone }\end{array}$ & Vuggy Limestone Conglomerate \\
\hline & SWC & 2312.00 & $\begin{array}{l}\text { Recrystalised coral } \\
\text { (predominantly) bioclastic } \\
\text { pack/floatstone }\end{array}$ & Vuggy Limestone Conglomerate \\
\hline & SWC & 2321.5 & $\begin{array}{l}\text { (Fenestral) Coral bioclastic } \\
\text { floatstone }\end{array}$ & Vuggy Limestone Conglomerate \\
\hline & SWC & 2329 & $\begin{array}{l}\text { Mottled mollusc bioclastic } \\
\text { wacke/pack/grainstone }\end{array}$ & Fine, thinly bedded limestone \\
\hline & SWC & 2329.00 & $\begin{array}{l}\text { Bioclastic (mollusc \& imperforate } \\
\text { foraminifera) packstone }\end{array}$ & Fine, thinly bedded limestone \\
\hline & SWC & 2332 & $\begin{array}{l}\text { Mollusc \& imperforate } \\
\text { foraminifera bioclastic } \\
\text { wack/packstone }\end{array}$ & Fine, thinly bedded limestone \\
\hline & SWC & 2338.40 & $\begin{array}{l}\text { Imperforate foraminifera }(\& \\
\text { algal) grainstone }\end{array}$ & Fine, thinly bedded limestone \\
\hline & SWC & 2340.5 & $\begin{array}{l}\text { (Imperforate) Foraminifera } \\
\text { bioclastic grainstone }\end{array}$ & Fine, thinly bedded limestone \\
\hline & SWC & 2341.40 & $\begin{array}{l}\text { Imperforate foraminifera }(\& \\
\text { algal) grainstone }\end{array}$ & Fine, thinly bedded limestone \\
\hline & SWC & 2343 & $\begin{array}{l}\text { Imperforate foraminifera } \\
\text { bioclastic grainstone }\end{array}$ & Fine, thinly bedded limestone \\
\hline & SWC & 2347.57 & $\begin{array}{l}\text { Calcite cemented cavity infill or } \\
\text { coral replacement in (coral) } \\
\text { bioclastic pack/floatstone }\end{array}$ & Vuggy Limestone Conglomerate \\
\hline & SWC & 2357.00 & $\begin{array}{l}\text { Calcite cemented recrystalised } \\
\text { coral }\end{array}$ & Vuggy Limestone Conglomerate \\
\hline & SWC & 2361 & $\begin{array}{l}\text { Calcite cemented recrystalised } \\
\text { coral }\end{array}$ & Vuggy Limestone Conglomerate \\
\hline & SWC & 2363.5 & $\begin{array}{l}\text { Imperforate foraminifera \& } \\
\text { mollusc bioclastic grainstone }\end{array}$ & Fine, thinly bedded limestone \\
\hline & SWC & 2372 & Bioclastic wackestone & Vuggy Limestone Conglomerate \\
\hline & SWC & 2374 & $\begin{array}{l}\text { Cemented recrystalised coral } \\
\text { (?floatstone) }\end{array}$ & Vuggy Limestone Conglomerate \\
\hline & SWC & 2383.00 & $\begin{array}{l}\text { Mollusc bioclastic } \\
\text { wacke/packstone }\end{array}$ & Vuggy Limestone Conglomerate \\
\hline & SWC & 2387 & $\begin{array}{l}\text { Mollusc bioclastic } \\
\text { grain/packstone }\end{array}$ & Vuggy Limestone Conglomerate \\
\hline & SWC & 2388 & Cemented recrystalised coral & Fine, thinly bedded limestone \\
\hline & SWC & 2401.5 & $\begin{array}{l}\text { Recrystalised coral \& } \\
\text { foraminifera bioclastic } \\
\text { rud/pack/grainstone }\end{array}$ & Vuggy Limestone Conglomerate \\
\hline & SWC & 2413.00 & $\begin{array}{l}\text { Coral \& Halimeda bioclastic } \\
\text { pack/floatstone }\end{array}$ & Vuggy Limestone Conglomerate \\
\hline & SWC & 2415 & $\begin{array}{l}\text { Fractured cemented } \\
\text { recrystalised coral }\end{array}$ & Vuggy Limestone Conglomerate \\
\hline & SWC & 2422 & $\begin{array}{l}\text { Halimeda \& mollusc bioclastic } \\
\text { pack/grainstone }\end{array}$ & Vuggy Limestone Conglomerate \\
\hline & SWC & 2430 & $\begin{array}{l}\text { Fractured cemented } \\
\text { recrystalised coral }\end{array}$ & Vuggy Limestone Conglomerate \\
\hline & SWC & 2434 & $\begin{array}{l}\text { Brecciated cemented } \\
\text { recrystalised ?coral bioclastic } \\
\text { rud/packstone }\end{array}$ & Vuggy Limestone Conglomerate \\
\hline & SWC & 2437 & $\begin{array}{l}\text { Cemented recrystalised coral } \\
\text { rudstone }\end{array}$ & Vuggy Limestone Conglomerate \\
\hline
\end{tabular}




\begin{tabular}{|c|c|c|c|c|c|c|c|c|c|c|}
\hline FMI Facies & $\begin{array}{l}\text { Occurrence } \\
\text { in wells }\end{array}$ & $\begin{array}{l}\text { Texture seen } \\
\text { on } \\
\text { FMI image }\end{array}$ & $\begin{array}{l}\text { Conductivity } \\
\text { (from FMI) }\end{array}$ & $\begin{array}{l}\text { Clay } \\
\% \\
\text { (from } \\
\text { FEQL } \\
\text { ) }\end{array}$ & $\begin{array}{l}\text { Inclusio } \\
\text { ns (from } \\
\text { FMI) }\end{array}$ & $\begin{array}{l}\text { Laminat } \\
\text { ion } \\
\text { Density } \\
\text { (from } \\
\text { FMI) }\end{array}$ & $\begin{array}{l}\text { Connect } \\
\text { ivity } \\
\text { Index } \\
\text { Coeffici } \\
\text { ent } \\
\text { (from } \\
\text { FMI) }\end{array}$ & $\begin{array}{l}\text { Lithology } \\
\text { (from } \\
\text { samples) }\end{array}$ & $\begin{array}{l}\text { Sedimentary } \\
\text { features (from } \\
\text { samples) }\end{array}$ & $\begin{array}{l}\text { Diagenetic } \\
\text { features } \\
\text { (from } \\
\text { samples) }\end{array}$ \\
\hline Marl & $\begin{array}{l}\text { Elk-1: upper } \\
\text { imaged section. } \\
\text { Elk-2: upper } \\
\text { imaged section \& } \\
\text { upper part of } \\
\text { upper } 2 \\
\text { sequences. }\end{array}$ & $\begin{array}{l}\text { Subequal thin- } \\
\text { medium } \\
\text { conductive and } \\
\text { resistive beds } \\
\text { (faintly } \\
\text { laminated)(smooth } \\
\text { appearance) }\end{array}$ & $\begin{array}{l}\text { Very high } \\
(>22)\end{array}$ & $>35 \%$ & $\begin{array}{l}\text { Sub-equal } \\
\text { resistive \& } \\
\text { conductive } \\
\text { inclusions }\end{array}$ & $\begin{array}{l}\text { Intermedia } \\
\text { te }\end{array}$ & Medium & $\begin{array}{l}\text { Planktonic } \\
\text { foraminifera } \\
\text { wacke/mudstone } \\
\text { or marl }\end{array}$ & $\begin{array}{l}>90 \% \text { clay-sized } \\
\text { matrix (both } \\
\text { carbonate and } \\
\text { siliciclastic) and well- } \\
\text { preserved planktonic } \\
\text { foraminifera }\end{array}$ & $\begin{array}{l}\text { Mechanical } \\
\text { compaction of } \\
\text { foraminifera. Minor } \\
\text { equant calcite } \\
\text { cement in bioclast } \\
\text { chambers. }\end{array}$ \\
\hline $\begin{array}{l}\text { Argillaceous } \\
\text { Laminated- } \\
\text { thinly } \\
\text { bedded } \\
\text { limestone }\end{array}$ & $\begin{array}{l}\text { Elk-1: mainly } \\
\text { upper imaged } \\
\text { section \& upper } \\
\text { part of all } 3 \\
\text { sequences. Elk-2: } \\
\text { upper imaged } \\
\text { section \& upper } \\
\text { part of upper } 2 \\
\text { sequences. }\end{array}$ & $\begin{array}{l}\text { Sub-equal thin } \\
\text { resistive } \\
\text { beds \& conductive } \\
\text { laminations-thin } \\
\text { beds } \\
\text { (can have smooth } \\
\text { appearance) }\end{array}$ & $\begin{array}{l}\text { Medium } \\
(>22)\end{array}$ & $\begin{array}{l}10- \\
35 \%\end{array}$ & $\begin{array}{l}\text { Resistive } \\
\text { patches and } \\
\text { spots } \\
\text { abundant. } \\
\text { Conductive } \\
\text { inclusions }\end{array}$ & High $(>10)$ & Low & $\begin{array}{l}\text { Planktonic } \\
\text { foraminifera } \\
\text { wacke/packston } \\
\text { e }\end{array}$ & $\begin{array}{l}\text { Abundant clay-sized } \\
\text { matrix }(60-80 \%) \text { and } \\
\text { well preserved } \\
\text { planktonic } \\
\text { foraminifera. } \\
\text { Bioturbation is } \\
\text { common. } \\
\text { Disseminated, or } \\
\text { interbedded laminae } \\
\text { richer in, shallow } \\
\text { fragmented bioclasts }\end{array}$ & $\begin{array}{l}\text { Mechanical } \\
\text { compaction of } \\
\text { foraminifera. } \\
\text { Anastomosing } \\
\text { dissolution seams. } \\
\text { Silicicfication of } \\
\text { bioclastic rich } \\
\text { laminae. Minor } \\
\text { equant calcite } \\
\text { cement in bioclast } \\
\text { chambers. }\end{array}$ \\
\hline $\begin{array}{l}\text { Nodular } \\
\text { Limestone \& } \\
\text { Argillaceous } \\
\text { Limestone }\end{array}$ & $\begin{array}{l}\text { Elk-1: mainly } \\
\text { upper imaged } \\
\text { section \& upper } \\
\text { to middle part of } \\
\text { all } 3 \text { sequences. }\end{array}$ & $\begin{array}{l}\text { Nodular resistive } \\
\text { beds } \\
\text { with thin } \\
\text { conductive } \\
\text { beds or } \\
\text { laminations }\end{array}$ & $\begin{array}{l}\text { Low } \\
(<10)\end{array}$ & $<10 \%$ & $\begin{array}{l}\text { Resistive } \\
\text { patches and } \\
\text { spots } \\
\text { abundant. } \\
\text { Conductive } \\
\text { inclusions }\end{array}$ & High $(>10)$ & $\begin{array}{l}\text { Low- } \\
\text { medium }\end{array}$ & $\begin{array}{l}\text { Planktonic } \\
\text { foraminifera } \\
\text { wacke/packston } \\
\text { e plus probable } \\
\text { coral bioclastic } \\
\text { rud/packstones }\end{array}$ & $\begin{array}{l}\text { Planktonic } \\
\text { foraminifera rich } \\
\text { cuttings plus } \\
\text { fragemted corals } \\
\text { and larger benthic } \\
\text { foraminifera. }\end{array}$ & $\begin{array}{l}\text { Blocky to equant } \\
\text { cements. } \\
\text { Mechanical } \\
\text { compaction } \\
\text { features and } \\
\text { sutured grain } \\
\text { contacts. Some } \\
\text { cement may have } \\
\text { formed prior to } \\
\text { reworking of } \\
\text { bioclasts, but most } \\
\text { features are } \\
\text { probably burial } \\
\text { related. }\end{array}$ \\
\hline $\begin{array}{l}\text { Laminated- } \\
\text { thinly } \\
\text { bedded } \\
\text { limestone }\end{array}$ & $\begin{array}{l}\text { Elk-1: present in } \\
\text { all } 3 \text { sequences, } \\
\text { most common in } \\
\text { middle imaged } \\
\text { section. Elk-2: } \\
\text { present in all } 4\end{array}$ & $\begin{array}{l}\text { Thin resistive } \\
\text { beds } \\
\text { separated by } \\
\text { conductive } \\
\text { laminations }\end{array}$ & $\begin{array}{l}\text { Usually } \\
\text { low }(<22)\end{array}$ & $<10 \%$ & $\begin{array}{l}\text { Resistive } \\
\text { patches and } \\
\text { spots } \\
\text { abundant. } \\
\text { Conductive } \\
\text { inclusions }\end{array}$ & High $(>10)$ & Very low & $\begin{array}{l}\text { Planktonic } \\
\text { foraminifera } \\
\text { packstones } \\
\text { interbedded with } \\
\text { planktonic } \\
\text { foraminifera }\end{array}$ & $\begin{array}{l}\text { Abundant whole and } \\
\text { fragmented } \\
\text { planktonic } \\
\text { foraminifera with } \\
10 \% \text { and } 40 \% \\
\text { fragmented shallow }\end{array}$ & $\begin{array}{l}\text { Mechanical } \\
\text { compaction of } \\
\text { bioclasts and } \\
\text { sutured grain } \\
\text { contacts. } \\
\text { Dissolution seams }\end{array}$ \\
\hline
\end{tabular}




\begin{tabular}{|c|c|c|c|c|c|c|c|c|c|c|}
\hline & $\begin{array}{l}\text { sequences, most } \\
\text { common in middle } \\
\text { imaged section. }\end{array}$ & & & & & & & $\begin{array}{l}\text { bioclastic } \\
\text { packstones }\end{array}$ & $\begin{array}{l}\text { water bioclasts. } \\
\text { Some bioturbation. }\end{array}$ & $\begin{array}{l}\text { (common along } \\
\text { lithological } \\
\text { boundaries). } \\
\text { Equant cements in } \\
\text { bioclasts. }\end{array}$ \\
\hline $\begin{array}{l}\text { Mottled/biotur } \\
\text { bated } \\
\text { limestone }\end{array}$ & $\begin{array}{l}\text { Elk-1: minor } \\
\text { facies, most } \\
\text { common in middle } \\
\text { imaged section. }\end{array}$ & $\begin{array}{l}\text { Medium-thickly } \\
\text { bedded limestone } \\
\text { highly fractured } \\
\text { and } \\
\text { possibly altered } \\
\text { (possibly } \\
\text { bioturbated) } \\
\end{array}$ & $\begin{array}{l}\text { Low } \\
(<10)\end{array}$ & $<10 \%$ & $\begin{array}{l}\text { Resistive } \\
\text { patches and } \\
\text { spots } \\
\text { abundant. } \\
\text { Conductive } \\
\text { inclusions }\end{array}$ & $\begin{array}{l}\text { Low- } \\
\text { medium } \\
\text { ( }>10 \text { due } \\
\text { to } \\
\text { skewing } \\
\text { by } \\
\text { fractures) }\end{array}$ & Very low & None available & $\mathrm{N} / \mathrm{A}$ & $\mathrm{N} / \mathrm{A}$ \\
\hline $\begin{array}{l}\text { Fine-medium } \\
\text { limestone } \\
\text { conglomerate/ } \\
\text { breccia }\end{array}$ & $\begin{array}{l}\text { Elk-2: present in } \\
\text { lower } 3 \\
\text { sequences, most } \\
\text { common in middle } \\
\text { imaged section. }\end{array}$ & $\begin{array}{l}\text { Resistive clasts } \\
\text { (angular-rounded) } \\
\text { (usually up to } \\
\text { granule to pebble) } \\
\text { within a } \\
\text { conductive matrix }\end{array}$ & $\begin{array}{l}\text { Usually } \\
\text { high }(>22)\end{array}$ & $\begin{array}{l}\text { V.low - } \\
\text { nil }\end{array}$ & $\begin{array}{l}\text { Conductive } \\
\text { patches and } \\
\text { spots } \\
\text { abundant; } \\
\text { Resistive } \\
\text { inclusions } \\
\text { very } \\
\text { low }\end{array}$ & $\begin{array}{l}\text { Very Low } \\
(<<10)\end{array}$ & $\begin{array}{l}\text { Low to } \\
\text { medium }\end{array}$ & $\begin{array}{l}\text { Most samples } \\
\text { are coral, larger } \\
\text { benthic } \\
\text { foraminifera and } \\
\text { carbonate } \\
\text { lithoclastic } \\
\text { pack/rudstone/br } \\
\text { eccias, but also } \\
\text { includes } \\
\text { planktonic and } \\
\text { larger benthic } \\
\text { foraminifera } \\
\text { bioclastic } \\
\text { packstones, and } \\
\text { dolomitised } \\
\text { foraminifera and } \\
\text { echinoderm } \\
\text { bioclastic } \\
\text { packstones }\end{array}$ & $\begin{array}{l}\text { Well-preserved } \\
\text { planktonic } \\
\text { foraminifera, } \\
\text { together with } \\
\text { fragmented larger } \\
\text { benthic foraminifera, } \\
\text { coral, echinoderm } \\
\text { coralline algae and } \\
\text { bryozoa debris. } \\
\text { Lithoclasts include } \\
\text { planktonic } \\
\text { foraminifera } \\
\text { wackestones and } \\
\text { bioclastic } \\
\text { packstones. }\end{array}$ & $\begin{array}{l}\text { Mechanical } \\
\text { breakage of } \\
\text { grains, sutured } \\
\text { contacts and } \\
\text { minor equant } \\
\text { cements. Some } \\
\text { samples contain } \\
\text { significant post- } \\
\text { depositional } \\
\text { dolomite. } \\
\text { Syntaxial } \\
\text { overgrowths on } \\
\text { echinoderm } \\
\text { material }\end{array}$ \\
\hline $\begin{array}{l}\text { Medium- } \\
\text { thickly } \\
\text { bedded } \\
\text { limestone }\end{array}$ & $\begin{array}{l}\text { Elk-1: middle to } \\
\text { lower imaged } \\
\text { section \& making } \\
\text { up the lower part } \\
\text { of the lower } 2 \\
\text { sequences. Elk-2: } \\
\text { most common in } \\
\text { middle imaged } \\
\text { section. }\end{array}$ & $\begin{array}{l}\text { Subequal medium } \\
\text { to thick } \\
\text { resistive \& } \\
\text { conductive } \\
\text { interbeds; or } \\
\text { medium to thick } \\
\text { resistive beds with } \\
\text { conductive lamina }\end{array}$ & $\begin{array}{l}\text { Usually } \\
\text { low }(<22)\end{array}$ & $<10 \%$ & $\begin{array}{l}\text { Variable, } \\
\text { yet } \\
\text { usually } \\
\text { resistive } \\
\text { patches and } \\
\text { spots } \\
\text { abundant. } \\
\text { Conductive } \\
\text { inclusions }\end{array}$ & Low $(<10)$ & Very low & $\begin{array}{l}\text { Planktonic } \\
\text { foraminifera } \\
\text { bioclastic } \\
\text { packstone and ? } \\
\text { dolomitised } \\
\text { carbonate } \\
\text { lithoclastic \& } \\
\text { bioclastic } \\
\text { pack/rudstone/br } \\
\text { eccia }\end{array}$ & $\begin{array}{l}\text { Fragmented larger } \\
\text { benthic foraminifera, } \\
\text { coralline algae and } \\
\text { well preserved } \\
\text { planktonic } \\
\text { foraminifera }\end{array}$ & $\begin{array}{l}\text { Dolomitisation, } \\
\text { sutured grain } \\
\text { contacts, } \\
\text { mechanical } \\
\text { compaction, } \\
\text { syntaxial } \\
\text { overgrowths on } \\
\text { echinoderm } \\
\text { material and } \\
\text { equant cements. }\end{array}$ \\
\hline $\begin{array}{l}\text { Coarse } \\
\text { limestone } \\
\text { conglomerate/ } \\
\text { breccia }\end{array}$ & $\begin{array}{l}\text { Elk-2: present in } \\
\text { lower } 3 \\
\text { sequences, most } \\
\text { common in lower } \\
\text { imaged section. }\end{array}$ & $\begin{array}{l}\text { Resistive clasts } \\
\text { (angular-rounded) } \\
\text { (usually up to } \\
\text { pebble to cobble) } \\
\text { within a } \\
\text { conductive matrix }\end{array}$ & High (>22) & $\begin{array}{l}\text { V.low - } \\
\text { nil }\end{array}$ & $\begin{array}{l}\text { Conductive } \\
\text { patches and } \\
\text { spots } \\
\text { abundant; } \\
\text { Resistive } \\
\text { inclusions } \\
\text { very }\end{array}$ & $\begin{array}{l}\text { Very Low } \\
(<<10)\end{array}$ & $\begin{array}{l}\text { Low to } \\
\text { medium }\end{array}$ & $\begin{array}{l}\text { Coral and } \\
\text { planktonic } \\
\text { foraminifera } \\
\text { pack/floatstone } \\
\text { and dolomitised } \\
\text { breccias. }\end{array}$ & $\begin{array}{l}\text { Corals in micritic } \\
\text { matrix and in } \\
\text { breccias clasts } \\
\text { include planktonic } \\
\text { foraminifera } \\
\text { wackestone and } \\
\text { planktonic }\end{array}$ & $\begin{array}{l}\text { Compaction, } \\
\text { fractures, granular, } \\
\text { mosaic and } \\
\text { equant cements. } \\
\text { Dolomitisation } \\
\text { between clasts or } \\
\text { in fractures }\end{array}$ \\
\hline
\end{tabular}




\begin{tabular}{|c|c|c|c|c|c|c|c|c|c|c|}
\hline & & & & & low & & & & $\begin{array}{l}\text { foraminifera } \\
\text { bioclastic } \\
\text { wacke/packstone }\end{array}$ & \\
\hline $\begin{array}{l}\text { Strongly } \\
\text { dolomitised/ } \\
\text { altered } \\
\text { limestone }\end{array}$ & $\begin{array}{l}\text { Elk-2: lower } \\
\text { imaged section. }\end{array}$ & $\begin{array}{l}\text { Resistive clasts } \\
\text { (angular-rounded) } \\
\text { (usually upper } \\
\text { pebble/cobble) } \\
\text { within a } \\
\text { conductive matrix. } \\
\text { Blurred } \\
\text { boundaries } \\
\text { between } \\
\text { clasts and matrix. }\end{array}$ & $\begin{array}{l}\text { Very high } \\
\text { (>>22) }\end{array}$ & $\begin{array}{l}\text { V.low - } \\
\text { nil }\end{array}$ & $\begin{array}{l}\text { Conductive } \\
\text { patches and } \\
\text { spots } \\
\text { abundant; } \\
\text { Resistive } \\
\text { inclusions } \\
\text { very } \\
\text { low }\end{array}$ & $\begin{array}{l}\text { Very Low } \\
(<<10)\end{array}$ & Medium & None available & $\mathrm{N} / \mathrm{A}$ & $\mathrm{N} / \mathrm{A}$ \\
\hline
\end{tabular}

Table 1: Characteristics of the FMI facies from the Elk-1 and -2 wells, and their petrographic features. 


\begin{tabular}{|c|c|c|c|}
\hline $\begin{array}{l}\text { Zone/composite } \\
\text { facies }\end{array}$ & $\begin{array}{l}\text { Probable } \\
\text { sedimentology }\end{array}$ & $\begin{array}{l}\text { Environment of } \\
\text { deposition }\end{array}$ & $\begin{array}{l}\text { Water } \\
\text { depth/energy } \\
\text { conditions }\end{array}$ \\
\hline $\begin{array}{l}\text { Marl \& Argillcaeous } \\
\text { Limestone }\end{array}$ & $\begin{array}{l}\text { Clay-rich fine } \\
\text { limestone sediments }\end{array}$ & Basin Floor & $\begin{array}{l}\text { Very deep marine, } \\
\text { very low energy } \\
\text { conditions }\end{array}$ \\
\hline $\begin{array}{l}\text { Argillaceous Lm \& } \\
\text { nodular/laminated- } \\
\text { thinly } \\
\text { bedded Lm }\end{array}$ & $\begin{array}{l}\text { Clayey and non- } \\
\text { clayey fine limestone } \\
\text { sediments }\end{array}$ & Deep lower slope & $\begin{array}{l}\text { Deep marine, Low } \\
\text { energy conditions }\end{array}$ \\
\hline $\begin{array}{l}\text { Mainly laminated- } \\
\text { thinly bedded Lm }\end{array}$ & $\begin{array}{l}\text { Non-clayey fine } \\
\text { limestone sediments }\end{array}$ & Lower slope & $\begin{array}{l}\text { Deep marine, Low } \\
\text { energy conditions }\end{array}$ \\
\hline $\begin{array}{l}\text { Laminated-thickly } \\
\text { bedded Lm \& } \\
\text { Limestone } \\
\text { conglomerate/breccia }\end{array}$ & $\begin{array}{l}\text { Fine-medium } \\
\text { limestone sediments } \\
\text { w/ } \\
\text { debris flow limestone } \\
\text { breccia/conglomerate } \\
\text { deposits }\end{array}$ & Lower - Upper Slope & $\begin{array}{l}\text { Intermediate marine } \\
\text { depth. Generally low- } \\
\text { moderate } \\
\text { energy with } \\
\text { gravity driven flow } \\
\text { events }\end{array}$ \\
\hline $\begin{array}{l}\text { Mainly medium- } \\
\text { thickly bedded Lm }\end{array}$ & $\begin{array}{l}\text { Fine-medium } \\
\text { limestone sediments }\end{array}$ & Lower - Upper Slope & $\begin{array}{l}\text { Intermediate marine } \\
\text { depth. Generally low } \\
- \\
\text { moderate energy w/ } \\
\text { gravity driven flow } \\
\text { events }\end{array}$ \\
\hline $\begin{array}{l}\text { Coarse Lm } \\
\text { conglomerate/breccia, } \\
\text { minor medium-thickly } \\
\text { bedded Lm }\end{array}$ & $\begin{array}{l}\text { Debris flow and/or } \\
\text { storm-derived } \\
\text { limestone } \\
\text { breccia/conglomerate } \\
\text { deposits, w/ minor } \\
\text { fine-medium } \\
\text { limestone sediments }\end{array}$ & Upper Slope & $\begin{array}{l}\text { Shallow marine. } \\
\text { Generally high } \\
\text { energy } \\
\text { conditions }\end{array}$ \\
\hline $\begin{array}{l}\text { Coarse Lm } \\
\text { conglomerate/breccia }\end{array}$ & $\begin{array}{l}\text { Debris flow and/or } \\
\text { storm-derived } \\
\text { limestone } \\
\text { breccia/conglomerate } \\
\text { deposits }\end{array}$ & Upper Slope & $\begin{array}{l}\text { Very shallow marine. } \\
\text { Generally high } \\
\text { energy } \\
\text { conditions }\end{array}$ \\
\hline $\begin{array}{l}\text { Dolomitised/strongly } \\
\text { altered } \\
\text { Limestone }\end{array}$ & $\begin{array}{l}\text { Debris flow and/or } \\
\text { storm-derived } \\
\text { limestone } \\
\text { breccia/conglomerate } \\
\text { deposits }\end{array}$ & Upper Slope & $\begin{array}{l}\text { Very shallow marine. } \\
\text { Generally high } \\
\text { energy } \\
\text { conditions }\end{array}$ \\
\hline
\end{tabular}




\begin{tabular}{|c|c|c|c|c|c|c|c|c|c|}
\hline FMI Facies & $\begin{array}{l}\text { Occurrence } \\
\text { in wells }\end{array}$ & $\begin{array}{l}\text { Texture seen } \\
\text { on } \\
\text { FMl image }\end{array}$ & $\begin{array}{l}\text { Condu } \\
\text { ctivity } \\
\text { (from } \\
\text { FMI) }\end{array}$ & $\begin{array}{l}\text { Composit } \\
\text { ion (from } \\
\text { FEQL) }\end{array}$ & $\begin{array}{l}\text { Beddin } \\
\text { g or } \\
\text { laminati } \\
\text { ons } \\
\text { (from } \\
\text { FMI) }\end{array}$ & $\begin{array}{l}\text { Connect } \\
\text { ivity } \\
\text { Index } \\
\text { Coeffici } \\
\text { ent } \\
\text { (from } \\
\text { FMI) }\end{array}$ & $\begin{array}{l}\text { Lithology } \\
\text { (from } \\
\text { samples) }\end{array}$ & $\begin{array}{l}\text { Sedimentary } \\
\text { features (from } \\
\text { samples) }\end{array}$ & $\begin{array}{l}\text { Diagenetic } \\
\text { features } \\
\text { (from } \\
\text { samples) }\end{array}$ \\
\hline $\begin{array}{l}\text { Vuggy mottled } \\
\text { limestone } \\
\text { conglomerate/ } \\
\text { boundstone }\end{array}$ & $\begin{array}{l}\text { Antelope-2: upper } \\
\text { imaged section. }\end{array}$ & $\begin{array}{l}\text { Conductive vugs } \\
\& \text { holes \& mesh- } \\
\text { like } \\
\text { layering within a } \\
\text { generally distinct } \\
\text { resistive } \\
\text { conglomeratic/bou } \\
\text { ndstone } \\
\text { fabric. }\end{array}$ & $\begin{array}{l}\text { Low- } \\
\text { Medium }\end{array}$ & $\begin{array}{l}>70 \% \\
\text { limestone } \\
\text { (predominan } \\
\text { tly }>95 \% \\
\text { limestone) } \\
\text { with minor } \\
\text { dolomite }\end{array}$ & $\begin{array}{l}\text { Massive to } \\
\text { thickly } \\
\text { bedded }\end{array}$ & Low & $\begin{array}{l}\text { Coral, larger } \\
\text { benthic } \\
\text { foraminifera } \\
\text { and/or coralline } \\
\text { algal bioclastic } \\
\text { grain/pack/rudst } \\
\text { one }\end{array}$ & $\begin{array}{l}\text { Massive corals } \\
\text { many reworked, } \\
\text { coralline algae } \\
\text { (including } \\
\text { rhodoliths),fragment } \\
\text { ed larger benthic } \\
\text { foraminifera, } \\
\text { echinoderm debris, } \\
\text { bryozoa, barnacles } \\
\text { and planktonic } \\
\text { foraminifera. Grainy } \\
\text { rudstone units } \\
\text { gradationally } \\
\text { interbed with more } \\
\text { micritic algal } \\
\text { laminated units }\end{array}$ & $\begin{array}{l}\text { Heavily } \\
\text { recrystallised. } \\
\text { Early dissolution, } \\
\text { fracturing, solution } \\
\text { enhancement of } \\
\text { fractures and infill } \\
\text { by siliciclastic } \\
\text { sediment and } \\
\text { dolomite crystal } \\
\text { silt are common. } \\
\text { Mosaic to blocky } \\
\text { calcite cements } \\
\text { prevalent. } \\
\text { Stylolites and } \\
\text { dissolution seams } \\
\text { common in micritic } \\
\text { intervals. }\end{array}$ \\
\hline $\begin{array}{l}\text { Vuggy } \\
\text { limestone } \\
\text { conglomerate/ } \\
\text { boundstone }\end{array}$ & $\begin{array}{l}\text { Antelope-1: } \\
\text { partially } \\
\text { dolomitised lower } \\
\text { part of upper } \\
\text { imaged section. } \\
\text { Antelope-2: } \\
\text { predominantly } \\
\text { dolomitised lower } \\
\text { part of middle } \\
\text { imaged section. }\end{array}$ & $\begin{array}{l}\text { Abundant } \\
\text { conductive vugs \& } \\
\text { holes } \\
\text { within a generally } \\
\text { distinct resistive } \\
\text { conglomeratic/bou } \\
\text { ndstone fabric }\end{array}$ & Low & $\begin{array}{l}\text { Predominant } \\
\text { ly limestone } \\
\text { with up to } \\
20-40 \% \\
\text { dolomite }\end{array}$ & $\begin{array}{l}\text { Thick } \\
\text { bedded }\end{array}$ & Low & $\begin{array}{l}\text { Coral and } \\
\text { mollusc } \\
\text { bioclastic } \\
\text { pack/grainfloatst } \\
\text { one }\end{array}$ & $\begin{array}{l}\text { Common coral, } \\
\text { mollusc and some } \\
\text { encrusting coralline } \\
\text { algal material. } \\
\text { Disseminated } \\
\text { coralline algal debris } \\
\text { and imperforate } \\
\text { foraminifera are also } \\
\text { present. }\end{array}$ & $\begin{array}{l}\text { Localised } \\
\text { micritisation, } \\
\text { aragonite } \\
\text { dissolution, } \\
\text { reddening. Some } \\
\text { dolomite replacing } \\
\text { matrix and as } \\
\text { cement. Late } \\
\text { leaching, } \\
\text { poikilotopic calcite } \\
\text { cements. }\end{array}$ \\
\hline $\begin{array}{l}\text { Highly } \\
\text { conductive } \\
\text { vuggy } \\
\text { dolomite } \\
\text { conglomerate/ } \\
\text { boundstone }\end{array}$ & $\begin{array}{l}\text { Antelope-1: upper } \\
\text { pervasively } \\
\text { dolomitised } \\
\text { imaged section. } \\
\text { Antelope-2: } \\
\text { middle pervasively } \\
\text { dolomitised } \\
\text { imaged section. }\end{array}$ & $\begin{array}{l}\text { Abundant } \\
\text { conductive vugs \& } \\
\text { holes } \\
\text { within a highly } \\
\text { conductive, } \\
\text { conglomeratic/bou } \\
\text { ndstone fabric. }\end{array}$ & High & $\begin{array}{l}>90-95 \% \\
\text { dolomite } \\
\text { with minor } \\
\text { limestone }\end{array}$ & $\begin{array}{l}\text { Massive to } \\
\text { thickly } \\
\text { bedded }\end{array}$ & High & $\begin{array}{l}\text { Dolomitised } \\
\text { (coral) bioclastic } \\
\text { wacke/pack/float } \\
\text { stone }\end{array}$ & $\begin{array}{l}\text { Dolomitised coral- } \\
\text { rich units with } \\
\text { common molluscs, } \\
\text { and imperforate } \\
\text { foraminifera. Less } \\
\text { common coralline } \\
\text { algae and Halimeda. }\end{array}$ & $\begin{array}{l}\text { Bioclast } \\
\text { micritisation, } \\
\text { aragonite } \\
\text { dissolution and } \\
\text { reddening. } \\
\text { Dolomite replacing } \\
\text { matrix and as } \\
\text { cement. Late } \\
\text { leaching, } \\
\text { poikilotopic calcite } \\
\text { cements. }\end{array}$ \\
\hline
\end{tabular}




\begin{tabular}{|c|c|c|c|c|c|c|c|c|c|}
\hline $\begin{array}{l}\text { Moderately } \\
\text { conductive } \\
\text { vuggy } \\
\text { dolomite } \\
\text { conglomerate/ } \\
\text { boundstone }\end{array}$ & $\begin{array}{l}\text { Antelope-1: upper } \\
\text { pervasively } \\
\text { dolomitised } \\
\text { imaged section. } \\
\text { Antelope-2: } \\
\text { middle pervasively } \\
\text { dolomitised } \\
\text { imaged section. }\end{array}$ & $\begin{array}{l}\text { Abundant } \\
\text { conductive vugs \& } \\
\text { holes } \\
\text { within a } \\
\text { moderately } \\
\text { conductive or } \\
\text { slightly resistive, } \\
\text { conglomeratic/bou } \\
\text { ndstone fabric. }\end{array}$ & Medium & $\begin{array}{l}>80 \% \\
\text { dolomite } \\
\text { with more } \\
\text { minor } \\
\text { limestone }\end{array}$ & $\begin{array}{l}\text { Massive to } \\
\text { thickly } \\
\text { bedded }\end{array}$ & Medium & $\begin{array}{l}\text { Dolomitised } \\
\text { coral bioclastic } \\
\text { pack/float/grains } \\
\text { tone }\end{array}$ & $\begin{array}{l}\text { Dolomitised coral- } \\
\text { rich units with } \\
\text { common molluscs, } \\
\text { and imperforate } \\
\text { foraminifera. Less } \\
\text { common coralline } \\
\text { algae and Halimeda. }\end{array}$ & $\begin{array}{l}\text { Bioclast } \\
\text { micritisation, } \\
\text { aragonite } \\
\text { dissolution and } \\
\text { reddening. } \\
\text { Dolomite replacing } \\
\text { matrix and as } \\
\text { cement. Late } \\
\text { leaching, } \\
\text { poikilotopic calcite } \\
\text { cements. } \\
\end{array}$ \\
\hline $\begin{array}{l}\text { Low } \\
\text { conductivity } \\
\text { vuggy } \\
\text { dolomite } \\
\text { conglomerate/ } \\
\text { boundstone }\end{array}$ & $\begin{array}{l}\text { Antelope-1: upper } \\
\text { pervasively and } \\
\text { partially } \\
\text { dolomitised } \\
\text { imaged section. } \\
\text { Antelope-2: } \\
\text { middle pervasively } \\
\text { and predominantly } \\
\text { dolomitised } \\
\text { imaged section. }\end{array}$ & $\begin{array}{l}\text { Conductive vugs } \\
\text { \& holes within a } \\
\text { generally resistive, } \\
\text { usually blurred } \\
\text { conglomeratic/bou } \\
\text { ndstone fabric. }\end{array}$ & Low & $\begin{array}{l}>60 \% \\
\text { dolomite } \\
\text { with more } \\
\text { minor } \\
\text { limestone }\end{array}$ & $\begin{array}{l}\text { Massive to } \\
\text { thickly } \\
\text { bedded }\end{array}$ & Low & $\begin{array}{l}\text { Dolomitised } \\
\text { (coral) bioclastic } \\
\text { (mollusc) } \\
\text { wacke/pack/grai } \\
\text { n/rudstone }\end{array}$ & $\begin{array}{l}\text { Dolomitised coral- } \\
\text { rich units with } \\
\text { common molluscs, } \\
\text { and imperforate } \\
\text { foraminifera. Less } \\
\text { common coralline } \\
\text { algae and Halimeda. }\end{array}$ & $\begin{array}{l}\text { Bioclast } \\
\text { micritisation, } \\
\text { aragonite } \\
\text { dissolution and } \\
\text { reddening. } \\
\text { Dolomite replacing } \\
\text { matrix and as } \\
\text { cement. Late } \\
\text { leaching, } \\
\text { poikilotopic calcite } \\
\text { cements. }\end{array}$ \\
\hline $\begin{array}{l}\text { Vuggy } \\
\text { limestone } \\
\text { conglomerate }\end{array}$ & $\begin{array}{l}\text { Antelope-2: lower } \\
\text { imaged section. }\end{array}$ & $\begin{array}{l}\text { Abundant } \\
\text { conductive vugs \& } \\
\text { holes } \\
\text { within a generally } \\
\text { distinct resistive } \\
\text { conglomeratic } \\
\text { fabric (no obvious } \\
\text { boundstone or } \\
\text { internal fabric) }\end{array}$ & $\begin{array}{l}\text { Low- } \\
\text { Medium }\end{array}$ & $\begin{array}{l}>98 \% \\
\text { limestone } \\
\text { with } \\
\text { occasional } \\
\text { very minor } \\
\text { clay or } \\
\text { dolomite }\end{array}$ & $\begin{array}{l}\text { Occasiona } \\
\text { I thick } \\
\text { bedding }\end{array}$ & Medium & $\begin{array}{l}\text { Coral bioclastic } \\
\text { (mollusc, } \\
\text { Halimeda, } \\
\text { foraminifera) } \\
\text { pack/grain/float/r } \\
\text { udstone and/or } \\
\text { limestone } \\
\text { breccia }\end{array}$ & $\begin{array}{l}\text { Coral-rich, other } \\
\text { locally common } \\
\text { elements include } \\
\text { molluscs, Halimeda, } \\
\text { perforate and } \\
\text { imperforate } \\
\text { foraminifera, } \\
\text { echinoderm debris } \\
\text { and carbonate } \\
\text { lithoclasts. }\end{array}$ & $\begin{array}{l}\text { Grain micritisation, } \\
\text { isopachous } \\
\text { cements (multiple } \\
\text { phases). } \\
\text { Glaebules, } \\
\text { alveolar texture } \\
\text { and Microcodium. } \\
\text { Dissolution, } \\
\text { common blocky } \\
\text { and neomorphic } \\
\text { cements. } \\
\text { Fracutres, minor } \\
\text { compaction and } \\
\text { minor dolomite } \\
\text { cements. }\end{array}$ \\
\hline $\begin{array}{l}\text { Fine, thinly } \\
\text { bedded } \\
\text { limestone }\end{array}$ & $\begin{array}{l}\text { Antelope-1: lower } \\
\text { imaged section. } \\
\text { Antelope-2: lower } \\
\text { imaged section. }\end{array}$ & $\begin{array}{l}\text { Fine grained, } \\
\text { typically thinly } \\
\text { bedded } \\
\text { limestone with } \\
\text { smooth } \\
\text { appearance. May } \\
\text { include minor } \\
\text { resisitive clasts. }\end{array}$ & $\begin{array}{l}\text { Low- } \\
\text { Medium }\end{array}$ & $\begin{array}{l}>98 \% \\
\text { limestone } \\
\text { with } \\
\text { occasional } \\
\text { very minor } \\
\text { clay or } \\
\text { dolomite }\end{array}$ & $\begin{array}{l}\text { Thin } \\
\text { bedding }\end{array}$ & Medium & $\begin{array}{l}\text { Bioclastic } \\
\text { (mollusc and } \\
\text { imperforate } \\
\text { foraminifera) } \\
\text { wacke/pack/ } \\
\text { grainstone }\end{array}$ & $\begin{array}{l}\text { Abundant molluscs } \\
\text { and imperforate } \\
\text { foraminifera. Less } \\
\text { common Halimeda, } \\
\text { coralline algae, } \\
\text { perforate } \\
\text { foraminifera and } \\
\text { minor corals. Many } \\
\text { bioclasts } \\
\text { fragmented. }\end{array}$ & $\begin{array}{l}\text { Grain micritisation, } \\
\text { glaebules, alveolar } \\
\text { texture and } \\
\text { Microcodium. } \\
\text { Dissolution, } \\
\text { common blocky } \\
\text { and neomorphic } \\
\text { cements. } \\
\text { Fracutres, minor } \\
\text { compaction and } \\
\text { minor dolomite }\end{array}$ \\
\hline
\end{tabular}




\begin{tabular}{|c|c|c|c|c|c|c|c|c|c|}
\hline & & & & & & & & & cements. \\
\hline $\begin{array}{l}\text { Limestone } \\
\text { conglomerate/ } \\
\text { boundstone }\end{array}$ & $\begin{array}{l}\text { Antelope-1: } \\
\text { middle imaged } \\
\text { section and minor } \\
\text { interbeds in lower } \\
\text { imaged section. }\end{array}$ & $\begin{array}{l}\text { Coarse texture } \\
\text { with distinct } \\
\text { resistive clasts in } \\
\text { a more conductive } \\
\text { groundmass. } \\
\text { Some internal, } \\
\text { wavy } \\
\text { (boundstone) } \\
\text { fabric. }\end{array}$ & $\begin{array}{l}\text { Low- } \\
\text { Medium }\end{array}$ & $\begin{array}{l}\text { Predominant } \\
l y>90 \% \\
\text { limestone }\end{array}$ & $\begin{array}{l}\text { Massive to } \\
\text { thickly } \\
\text { bedded }\end{array}$ & Low & $\begin{array}{l}\text { (Coral), mollusc } \\
\text { and imperforate } \\
\text { foraminifera } \\
\text { bioclastic pack/ } \\
\text { grainstones }\end{array}$ & $\begin{array}{l}\text { Common corals, } \\
\text { carbonate } \\
\text { lithoclasts, molluscs } \\
\text { and imperforate } \\
\text { foraminifera. } \\
\text { Coralline algae, } \\
\text { echinoderm debris } \\
\text { larger benthic } \\
\text { foraminifera and } \\
\text { Halimeda also } \\
\text { present. Many } \\
\text { components } \\
\text { fragmented and } \\
\text { abraded }\end{array}$ & $\begin{array}{l}\text { Micritisation, } \\
\text { isopachous } \\
\text { cements, } \\
\text { dissolution, } \\
\text { common blocky } \\
\text { and neomorphic } \\
\text { cements and } \\
\text { compaction. } \\
\text { Glaebular and } \\
\text { alveolar structure } \\
\text { as well as cavity } \\
\text { infills present. }\end{array}$ \\
\hline $\begin{array}{l}\text { Fine mottled } \\
\text { limestone }\end{array}$ & $\begin{array}{l}\text { Antelope-1: upper } \\
\text { part of middle } \\
\text { imaged section. }\end{array}$ & $\begin{array}{l}\text { Resistive spots } \\
\text { and patches } \\
\text { within a generally } \\
\text { conductive } \\
\text { mottled fabric }\end{array}$ & Medium & $\begin{array}{l}\text { Predominant } \\
\text { ly >95\% } \\
\text { limestone }\end{array}$ & $\begin{array}{l}\text { Massive to } \\
\text { metre- } \\
\text { scale } \\
\text { bedding } \\
\text { (?thick } \\
\text { bedding) }\end{array}$ & Low & $\begin{array}{l}\text { Partially } \\
\text { dolomitised coral } \\
\text { float/rud/packsto } \\
\text { nes or breccias } \\
\text { and mollusc, } \\
\text { imperforate } \\
\text { foraminifera and } \\
\text { coral bioclastic } \\
\text { grain/ } \\
\text { packstones }\end{array}$ & $\begin{array}{l}\text { Common corals, } \\
\text { carbonate } \\
\text { lithoclasts, molluscs } \\
\text { and imperforate } \\
\text { foraminifera. Many } \\
\text { components } \\
\text { fragmented and } \\
\text { abraded }\end{array}$ & $\begin{array}{l}\text { Dolomite may } \\
\text { replace matrix and } \\
\text { or earlier calcite } \\
\text { cements. Late } \\
\text { dolomite cements. } \\
\text { Micritisation, } \\
\text { isopachous } \\
\text { cements, } \\
\text { dissolution, } \\
\text { common blocky } \\
\text { and neomorphic } \\
\text { cements and } \\
\text { compaction. }\end{array}$ \\
\hline $\begin{array}{l}\text { Limestone } \\
\text { conglomerate/ } \\
\text { breccia }\end{array}$ & $\begin{array}{l}\text { Antelope-1: } \\
\text { middle and lower } \\
\text { imaged sections. }\end{array}$ & $\begin{array}{l}\text { Elliptical resistive } \\
\text { clasts, some with } \\
\text { distinct conductive } \\
\text { rims in a } \\
\text { moderately } \\
\text { conductive } \\
\text { groundmass }\end{array}$ & $\begin{array}{l}\text { Medium- } \\
\text { Low }\end{array}$ & $\begin{array}{l}>98 \% \\
\text { limestone }\end{array}$ & $\begin{array}{l}\text { Massive to } \\
\text { medium or } \\
\text { thickly } \\
\text { bedded }\end{array}$ & Low & $\begin{array}{l}\text { (Coral), mollusc } \\
\text { and imperforate } \\
\text { foraminifera } \\
\text { bioclastic pack/ } \\
\text { grainstones, } \\
\text { also minor } \\
\text { wackestones in } \\
\text { middle section. } \\
\text { In lower imaged } \\
\text { section larger } \\
\text { benthic } \\
\text { foraminifera } \\
\text { bioclastic } \\
\text { packstones with } \\
\text { subsidiary grain- } \\
\text { and floatstones. }\end{array}$ & $\begin{array}{l}\text { Middle section: } \\
\text { common corals, } \\
\text { carbonate } \\
\text { lithoclasts, molluscs } \\
\text { and imperforate } \\
\text { foraminifera. } \\
\text { Coralline algae, } \\
\text { echinoderm debris, } \\
\text { larger benthic } \\
\text { foraminifera and } \\
\text { Halimeda also } \\
\text { present and more } \\
\text { common in lower } \\
\text { section. Planktonic } \\
\text { foraminifera locally } \\
\text { present. Corals, } \\
\text { carbonate lithoclasts } \\
\text { and/or burrow infills } \\
\text { and bryozoa all } \\
\text { locally present in }\end{array}$ & $\begin{array}{l}\text { Middle section: } \\
\text { Micritisation, } \\
\text { isopachous } \\
\text { cements, } \\
\text { dissolution, } \\
\text { common blocky } \\
\text { and neomorphic } \\
\text { cements and } \\
\text { compaction. Lower } \\
\text { section: } \\
\text { micritisation, } \\
\text { syntaxial } \\
\text { overgrowths } \\
\text { compaction- } \\
\text { related grain } \\
\text { deformation, } \\
\text { breakage and } \\
\text { suturing common. } \\
\text { Throughout: } \\
\text { minor, localised } \\
\end{array}$ \\
\hline
\end{tabular}




\begin{tabular}{|c|c|c|c|c|c|c|c|c|c|}
\hline & & & & & & & & $\begin{array}{l}\text { lower section. Many } \\
\text { components } \\
\text { fragmented and } \\
\text { abraded. }\end{array}$ & $\begin{array}{l}\text { blocky to equant } \\
\text { cements dolomite } \\
\text { replacement of } \\
\text { matrix or clear } \\
\text { dolomite cements } \\
\text { and late leaching. }\end{array}$ \\
\hline $\begin{array}{l}\text { Fine, medium- } \\
\text { bedded } \\
\text { limestone }\end{array}$ & $\begin{array}{l}\text { Antelope-1: } \\
\text { middle imaged } \\
\text { section. }\end{array}$ & $\begin{array}{l}\text { Generally has a } \\
\text { smooth, but } \\
\text { sometimes } \\
\text { brecciated } \\
\text { appearance and is } \\
\text { resistive to slightly } \\
\text { conductive. }\end{array}$ & $\begin{array}{l}\text { Medium- } \\
\text { Low }\end{array}$ & $\begin{array}{l}>98 \% \\
\text { limestone }\end{array}$ & $\begin{array}{l}\text { Medium } \\
\text { bedded }\end{array}$ & Low & $\begin{array}{l}\text { Middle section: } \\
\text { Mollusc and } \\
\text { imperforate } \\
\text { foraminifera } \\
\text { bioclastic pack/ } \\
\text { grainstones and } \\
\text { wackestones. } \\
\text { Lower section: } \\
\text { Fine to medium } \\
\text { grained } \\
\text { echinoderm (and } \\
\text { foraminifera) } \\
\text { bioclastic } \\
\text { packstones. }\end{array}$ & $\begin{array}{l}\text { Molluscs and } \\
\text { imperforate } \\
\text { foraminifera } \\
\text { common in middle } \\
\text { section. Coralline } \\
\text { algae, echinoderm } \\
\text { debris larger benthic } \\
\text { foraminifera and } \\
\text { Halimeda also } \\
\text { present and } \\
\text { common in lower } \\
\text { section. Planktonic } \\
\text { foraminifera locally } \\
\text { present. Many } \\
\text { components } \\
\text { fragmented and } \\
\text { abraded. }\end{array}$ & $\begin{array}{l}\text { Middle section: } \\
\text { Micritisation, } \\
\text { isopachous } \\
\text { cements, } \\
\text { dissolution, } \\
\text { common blocky } \\
\text { and neomorphic } \\
\text { cements and } \\
\text { compaction. Lower } \\
\text { section: } \\
\text { micritisation, } \\
\text { syntaxial } \\
\text { overgrowths } \\
\text { compaction- } \\
\text { related grain } \\
\text { deformation, } \\
\text { breakage and } \\
\text { suturing common. } \\
\text { Throughout: } \\
\text { minor, localised } \\
\text { blocky to equant } \\
\text { cements dolomite } \\
\text { replacement of } \\
\text { matrix or clear } \\
\text { dolomite cements } \\
\text { and late leaching. }\end{array}$ \\
\hline
\end{tabular}




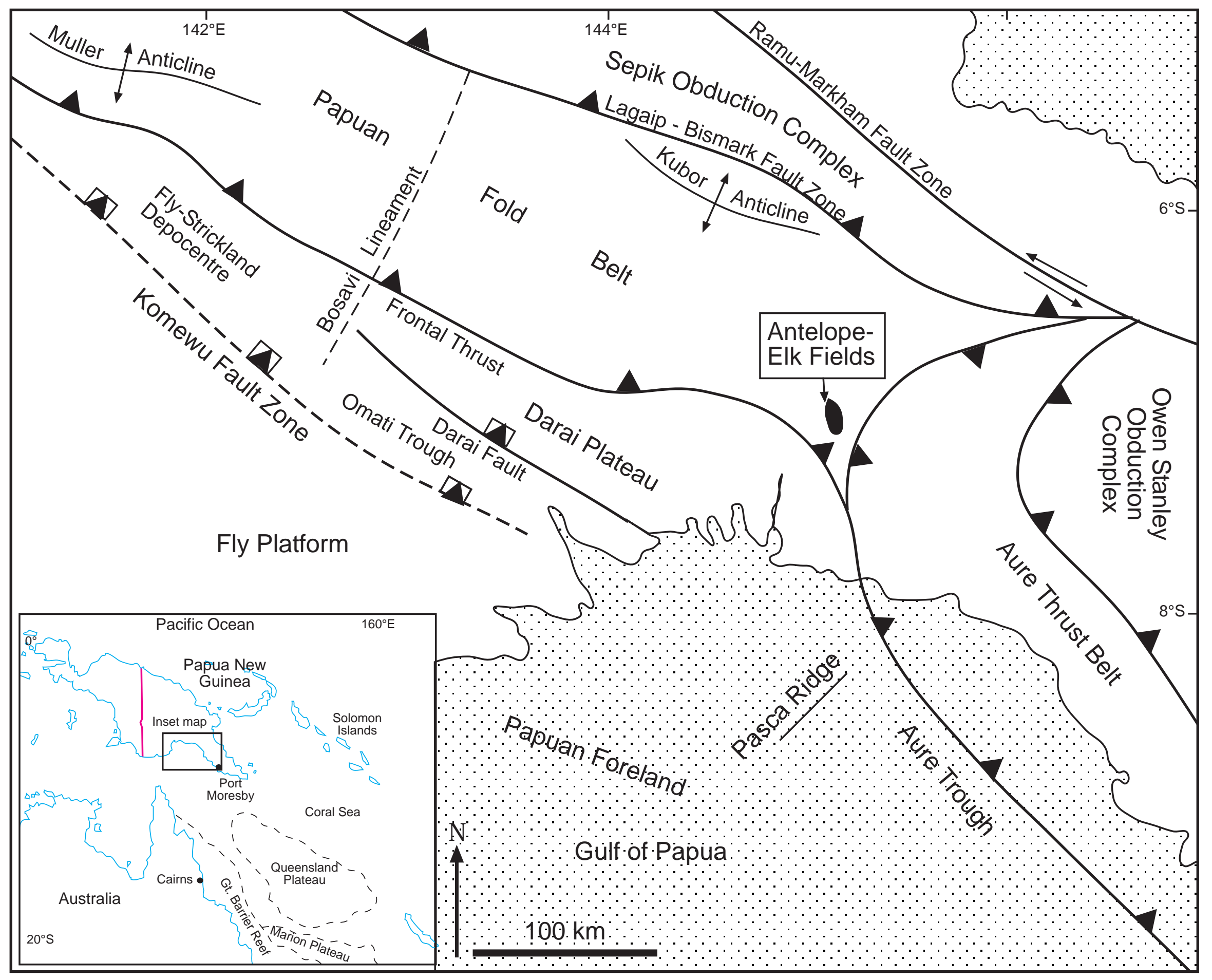




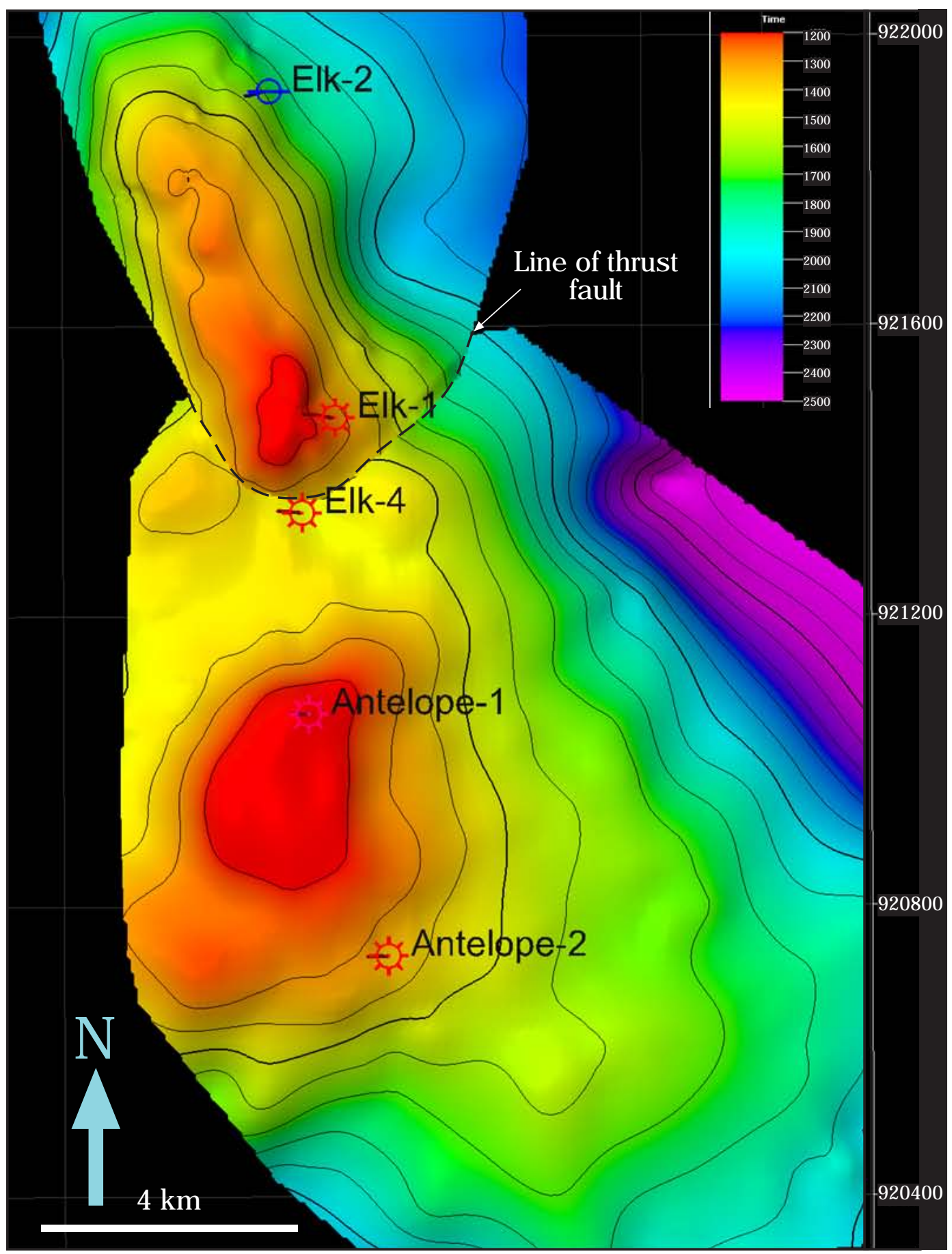




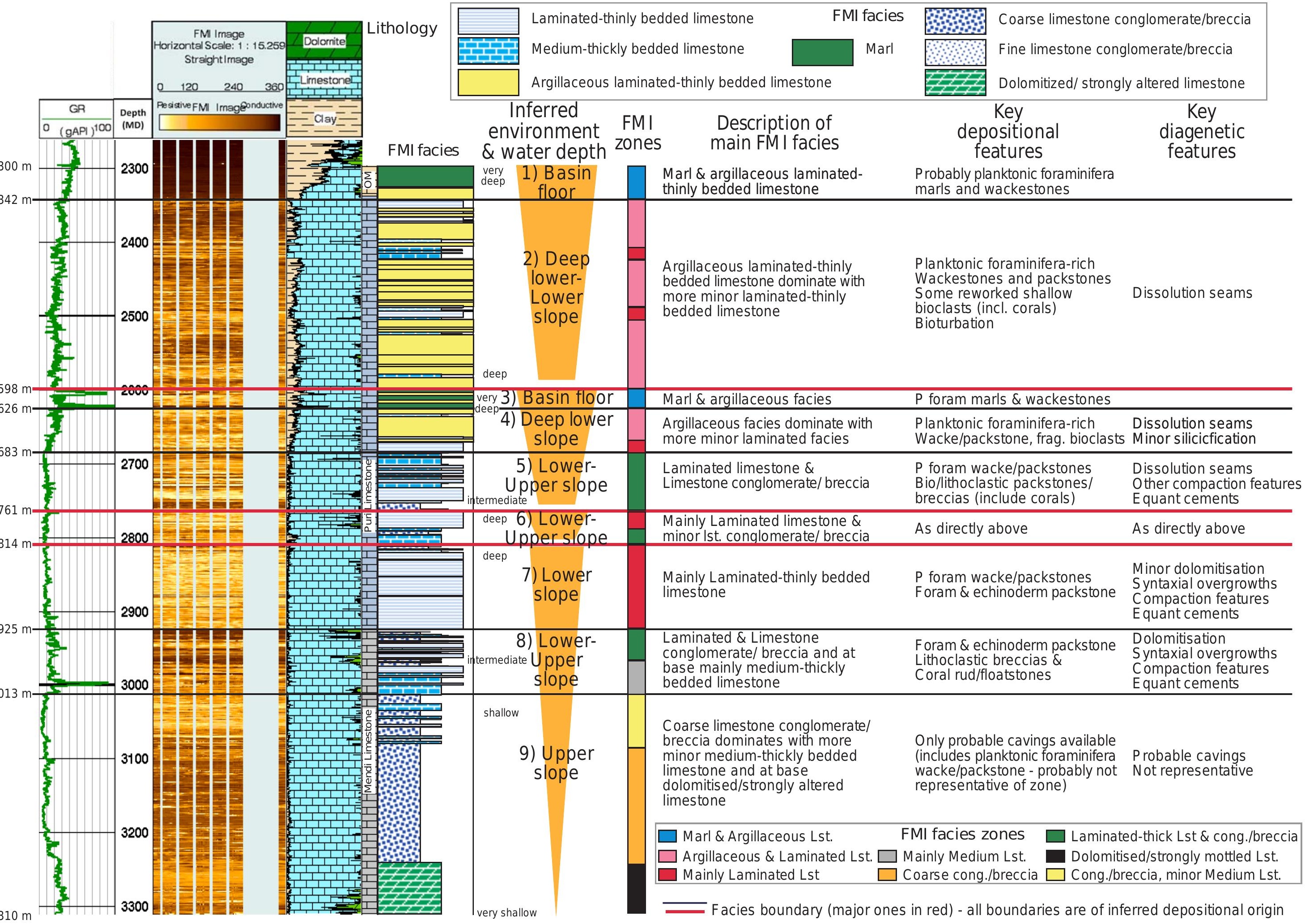




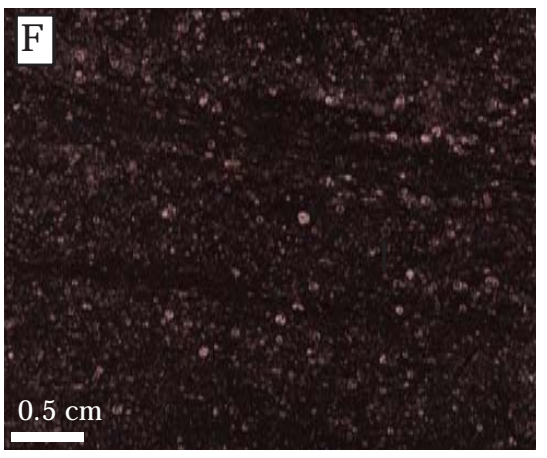

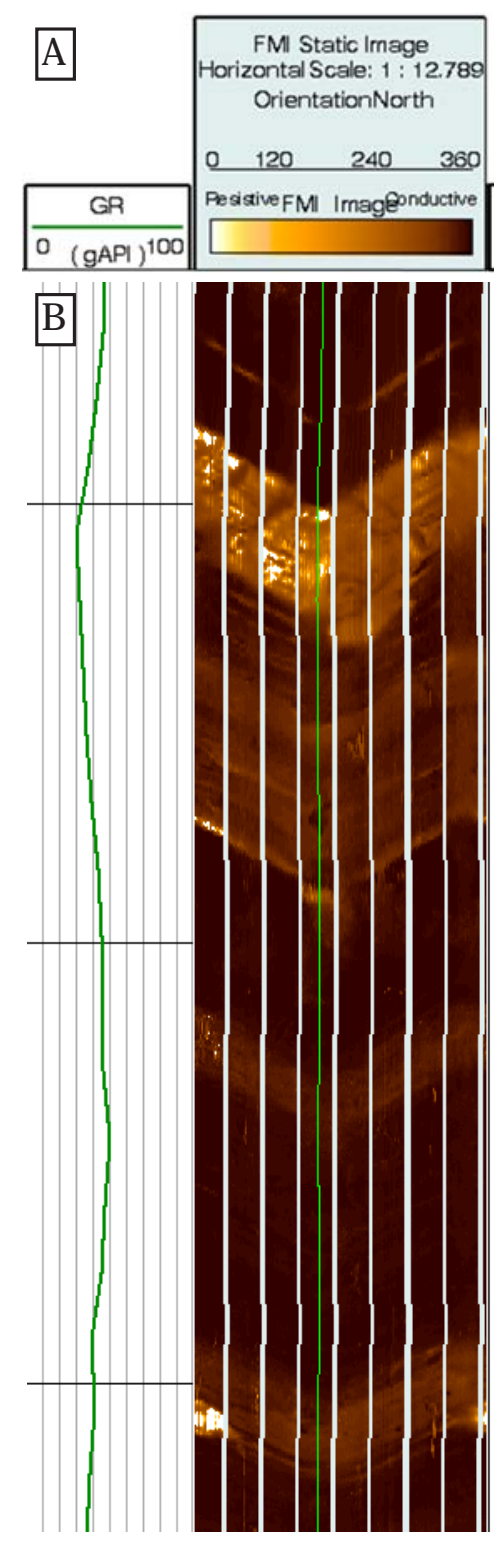
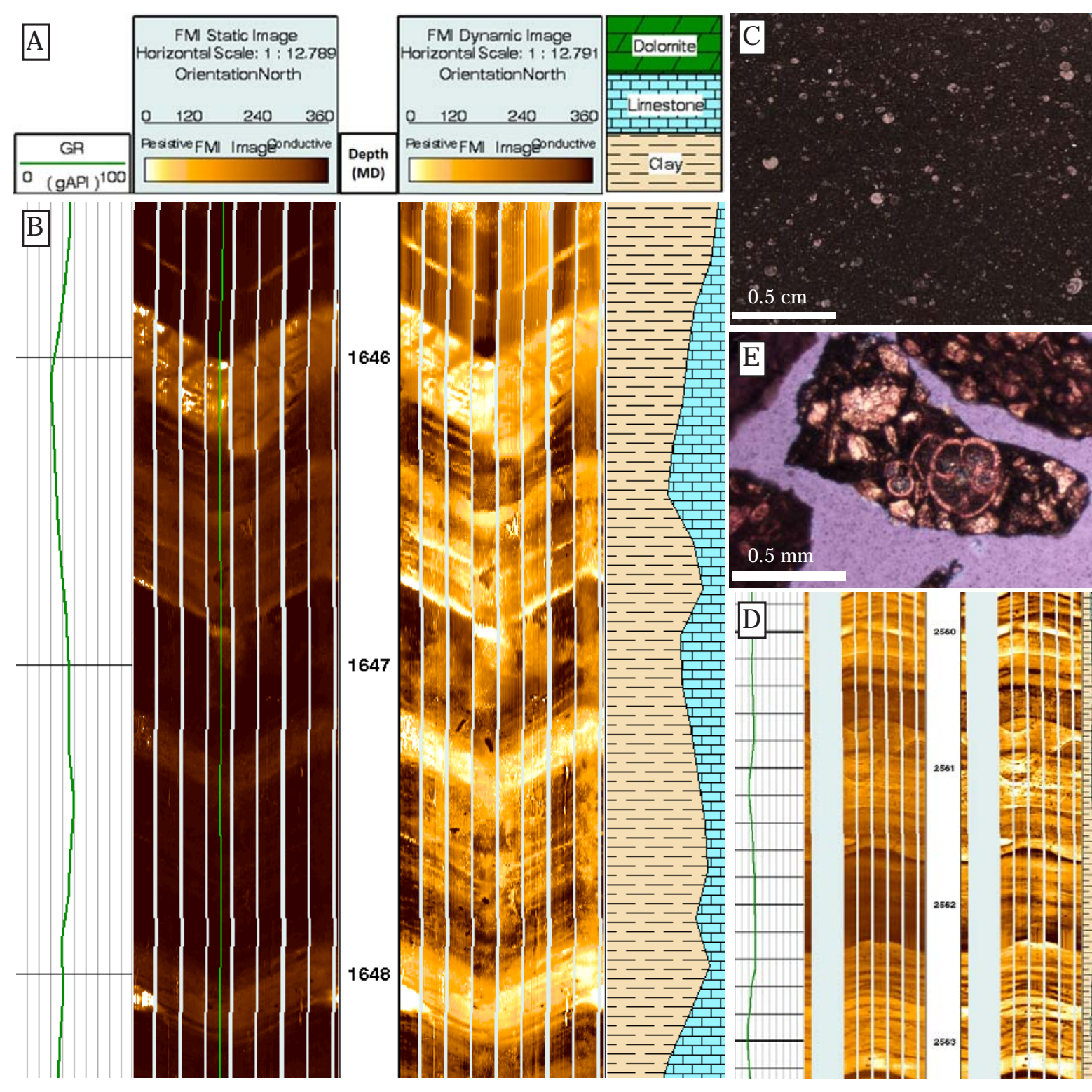

$0.5 \mathrm{~cm}$.

จุ

1646
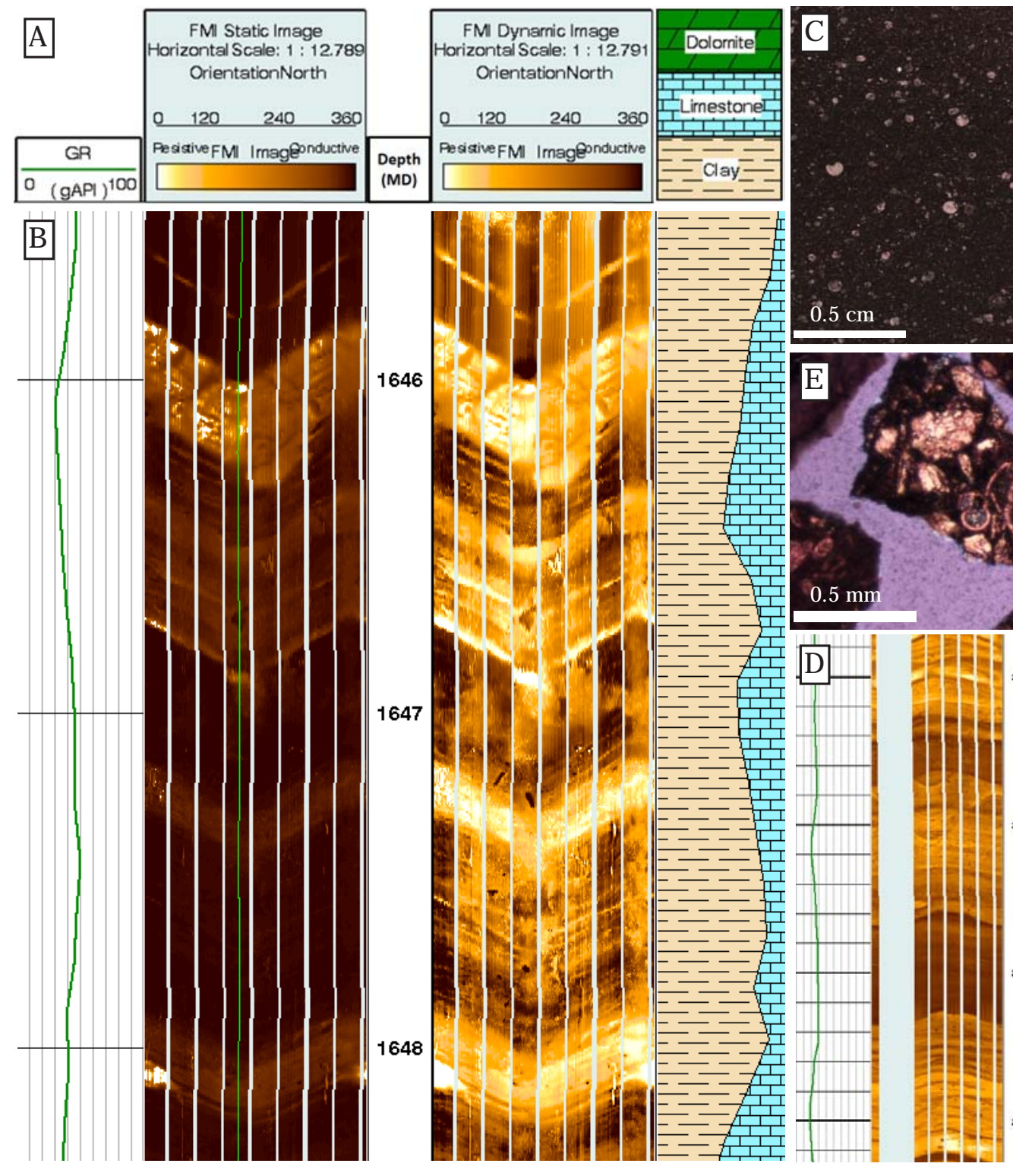

(2)

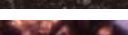

1648

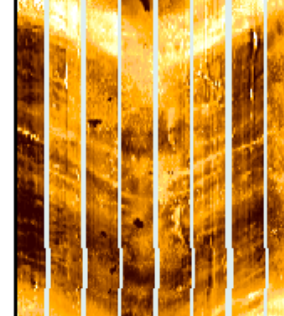

1647

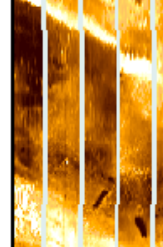

4.

8

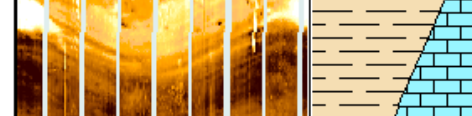

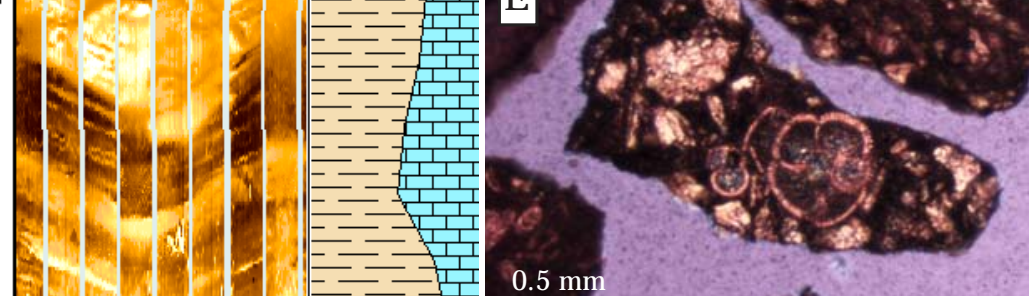

N.
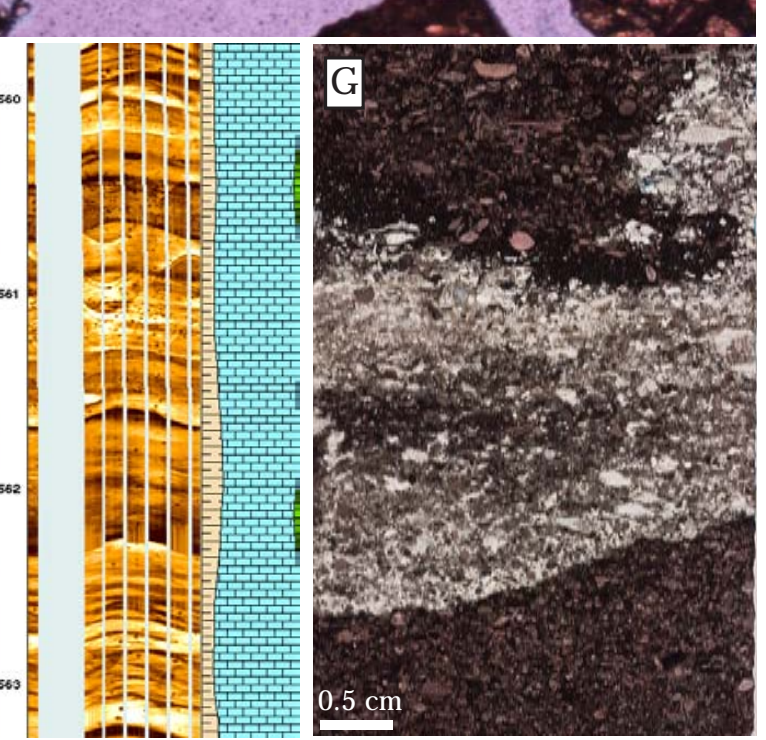


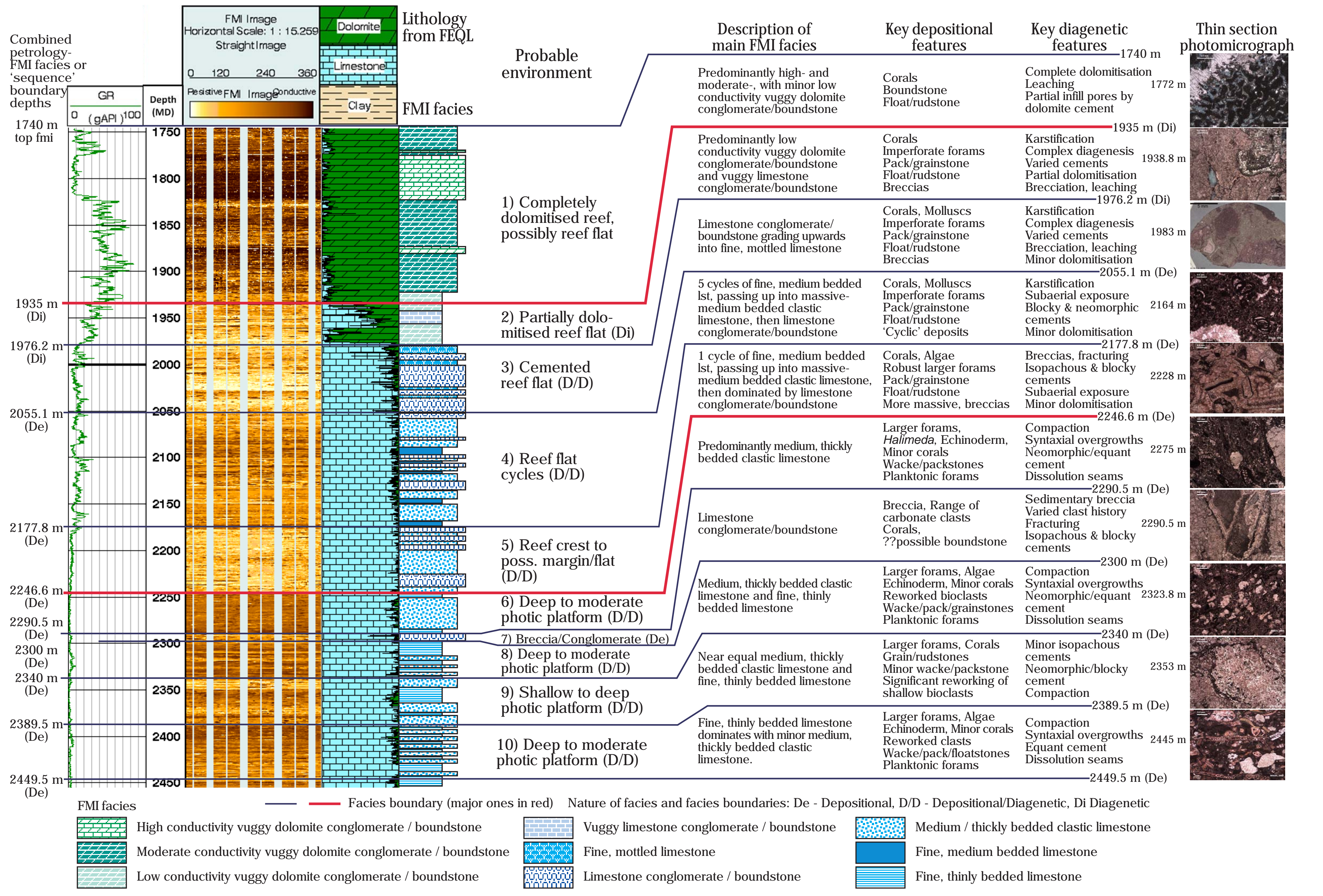




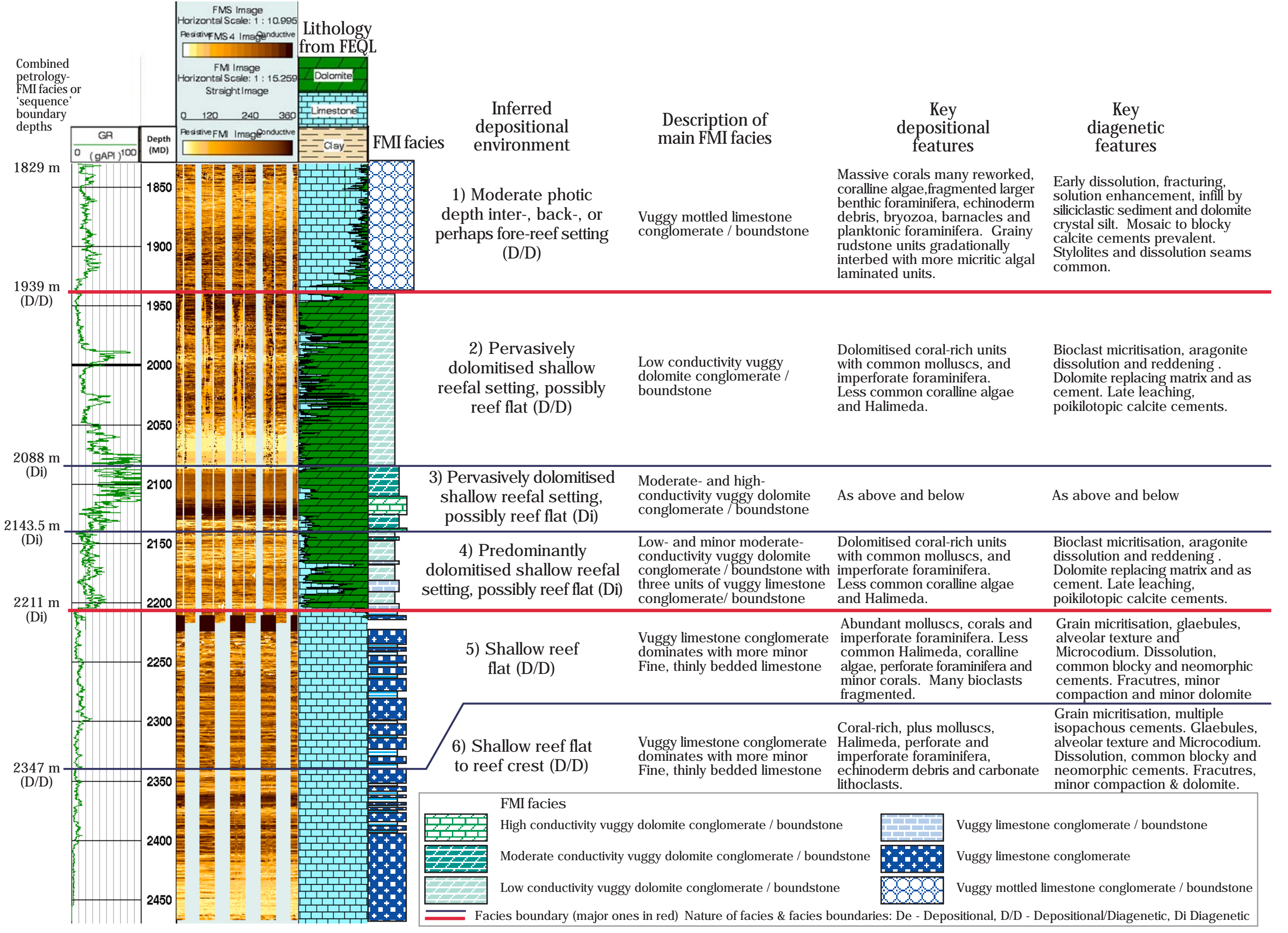



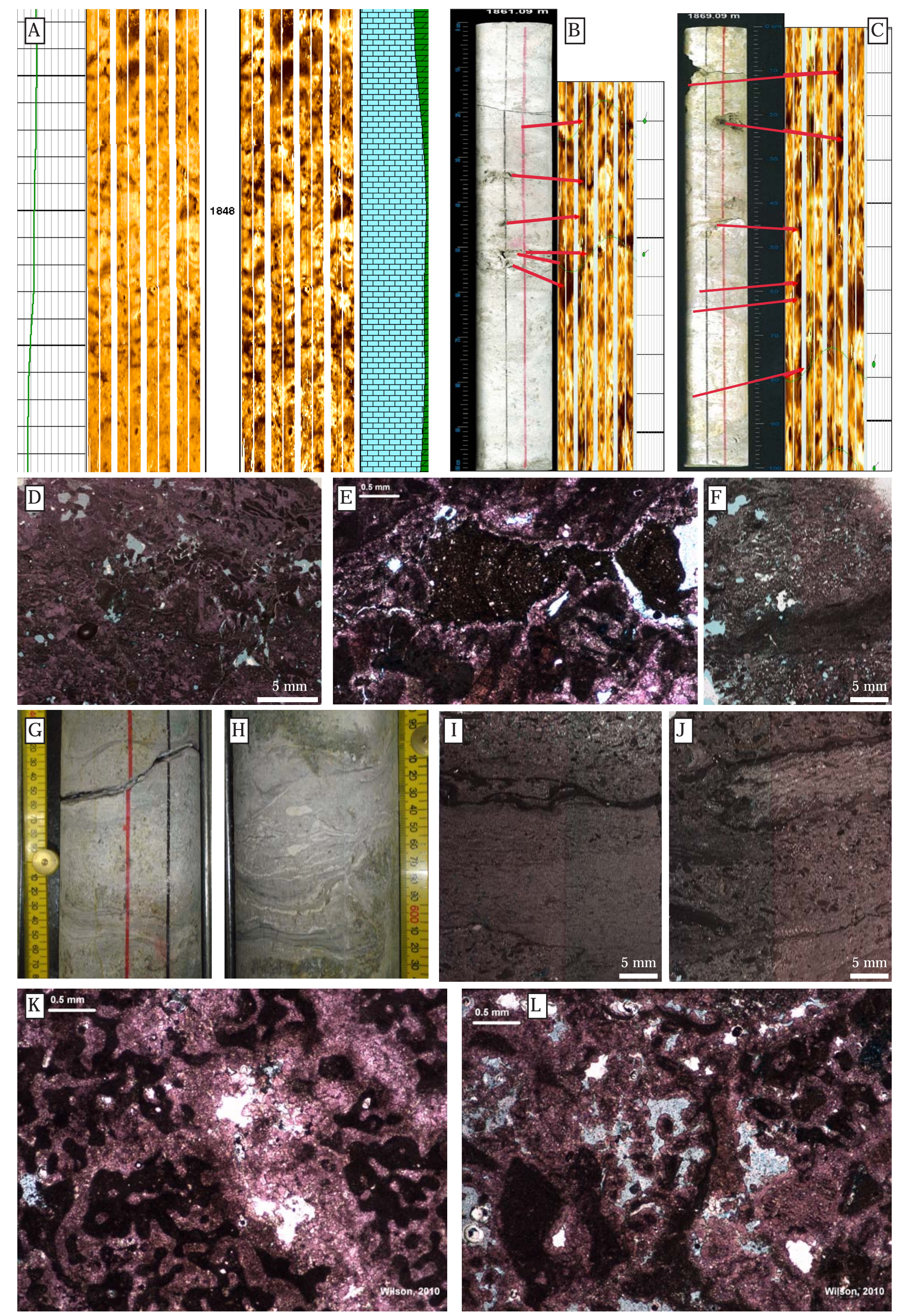


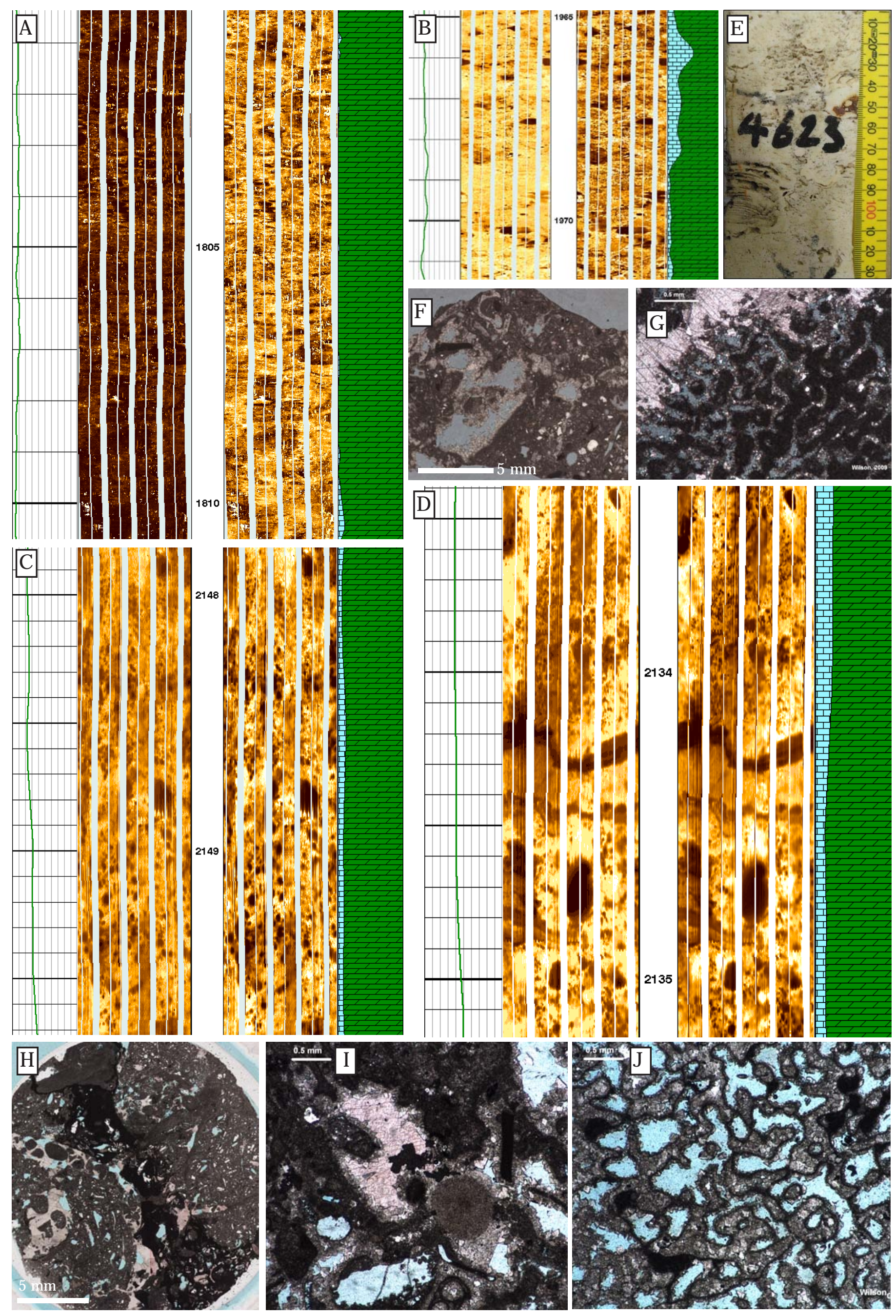




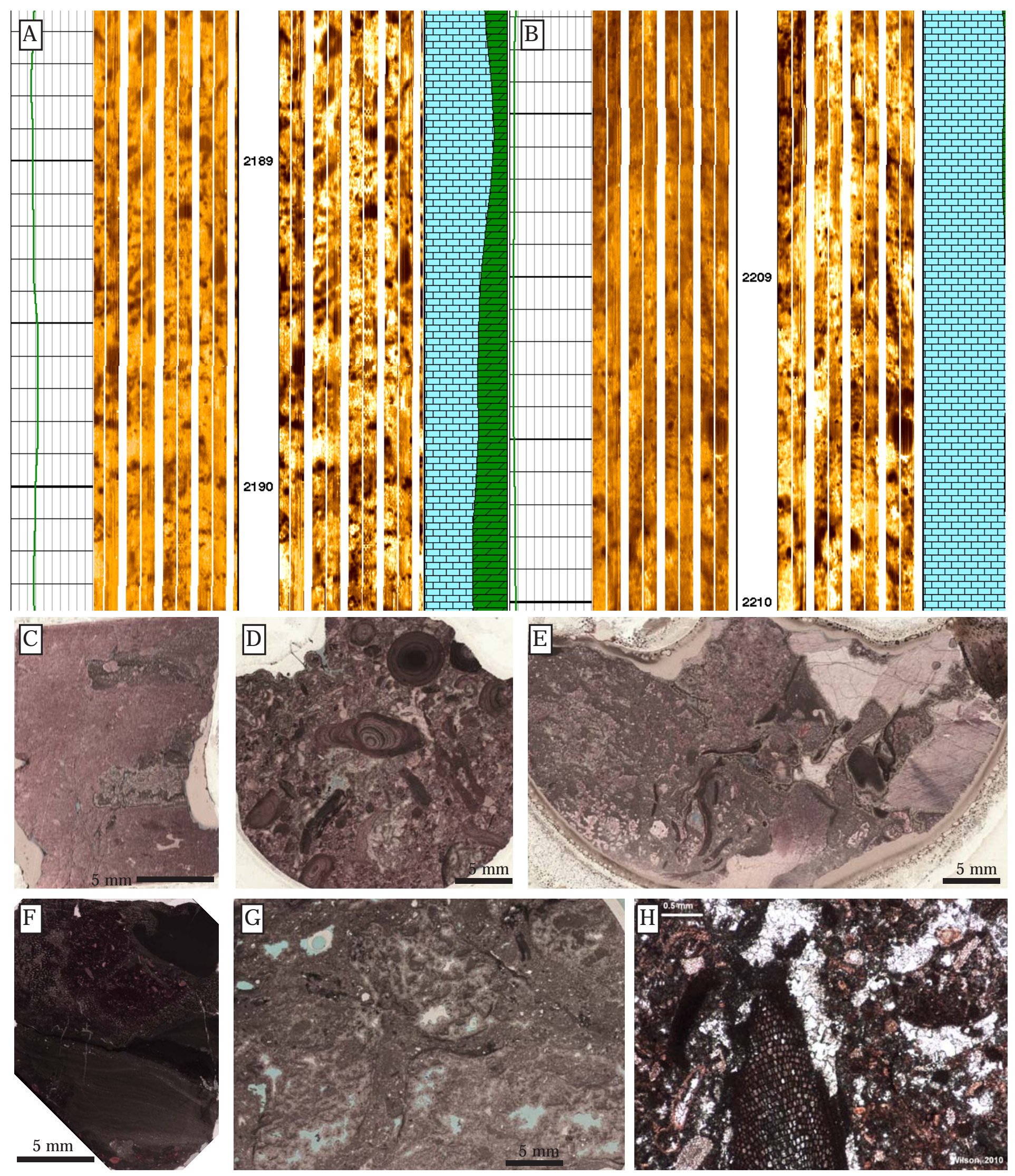




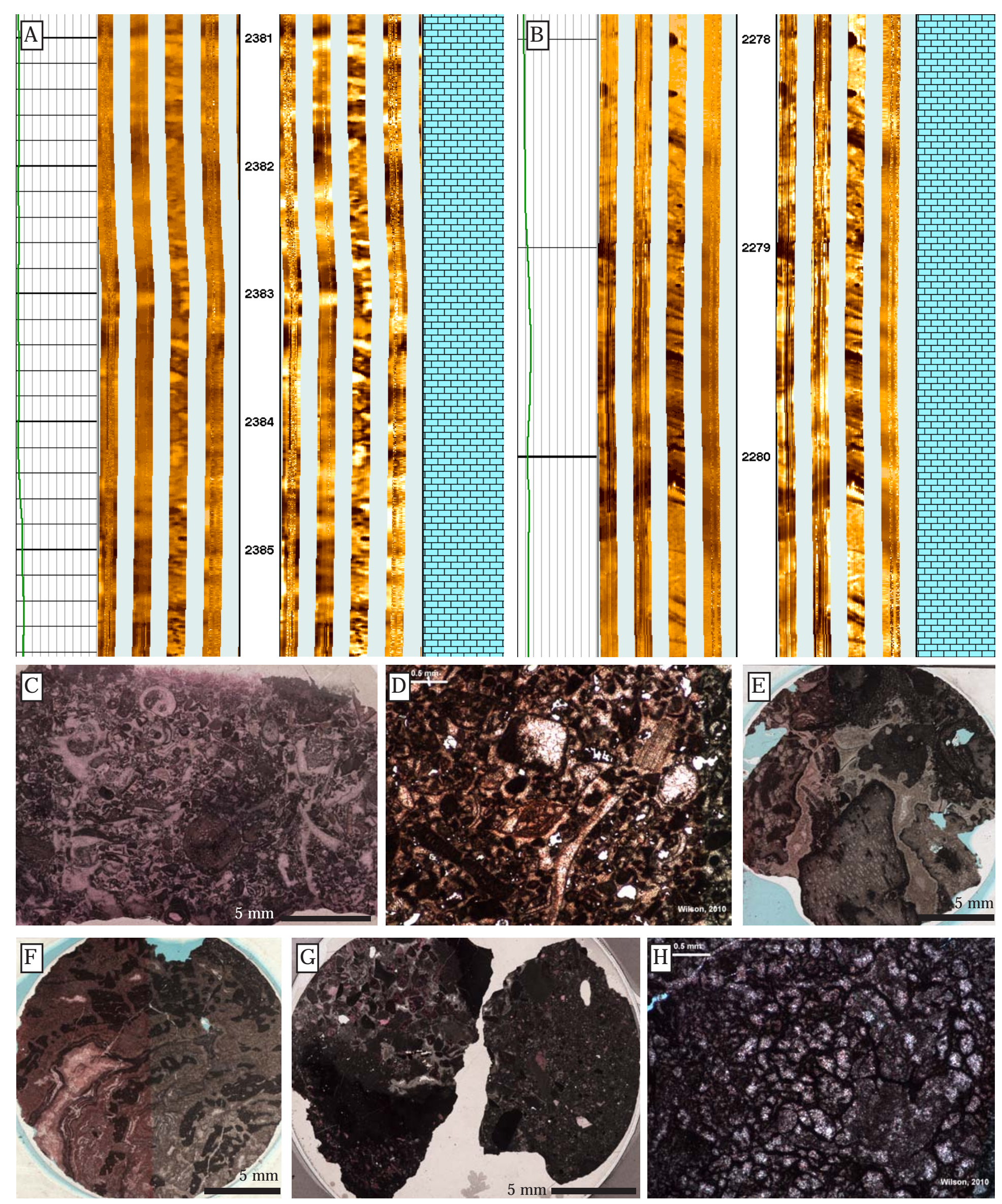




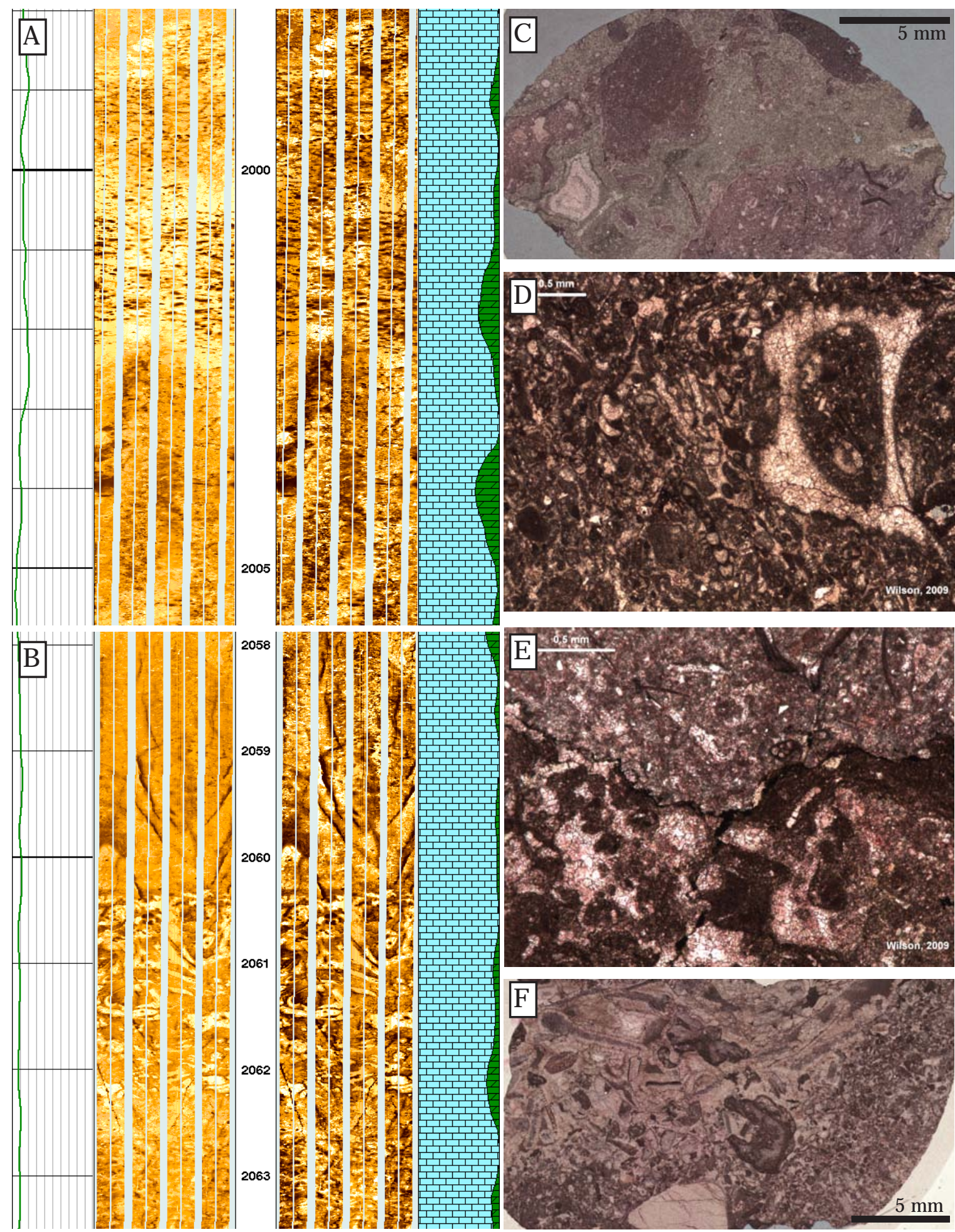



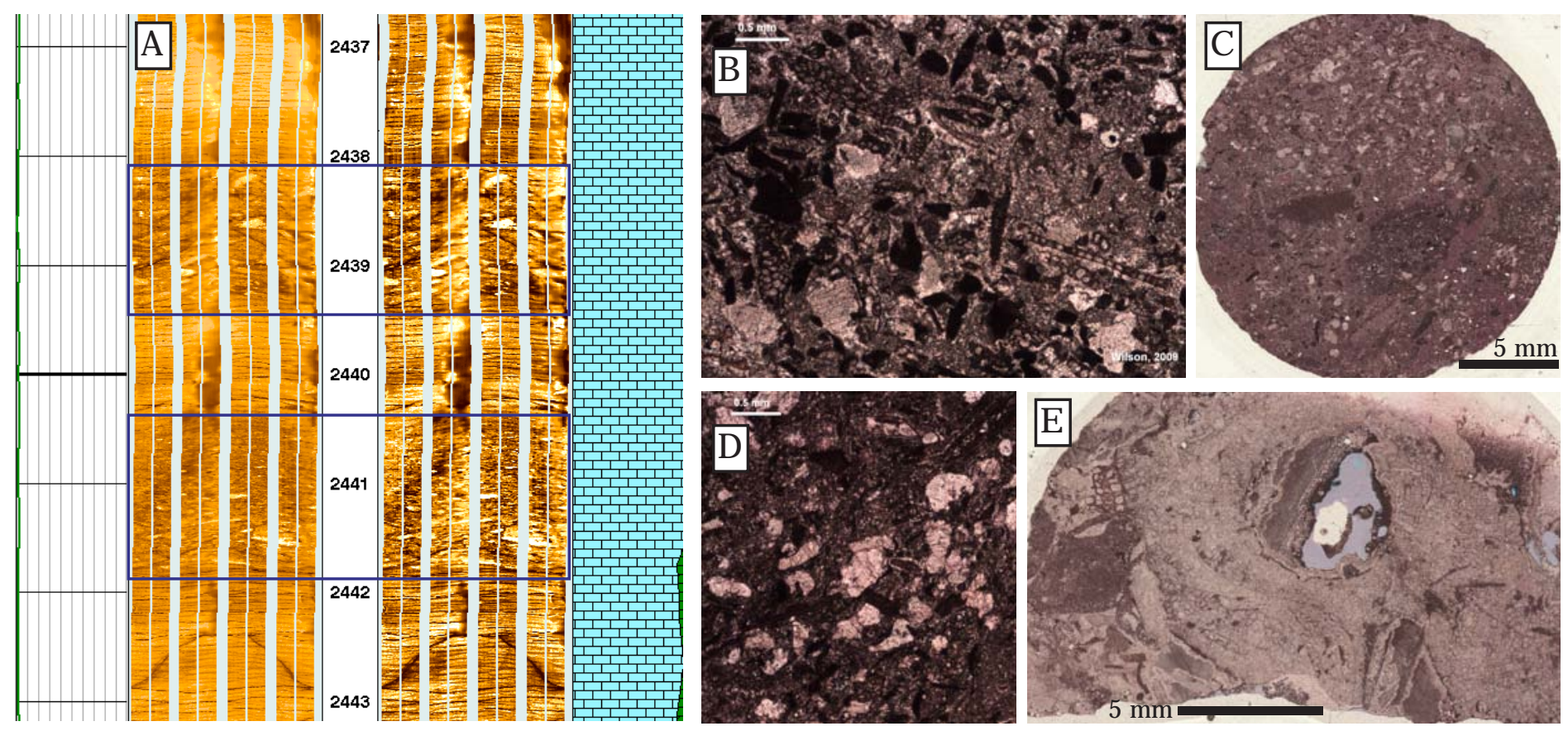


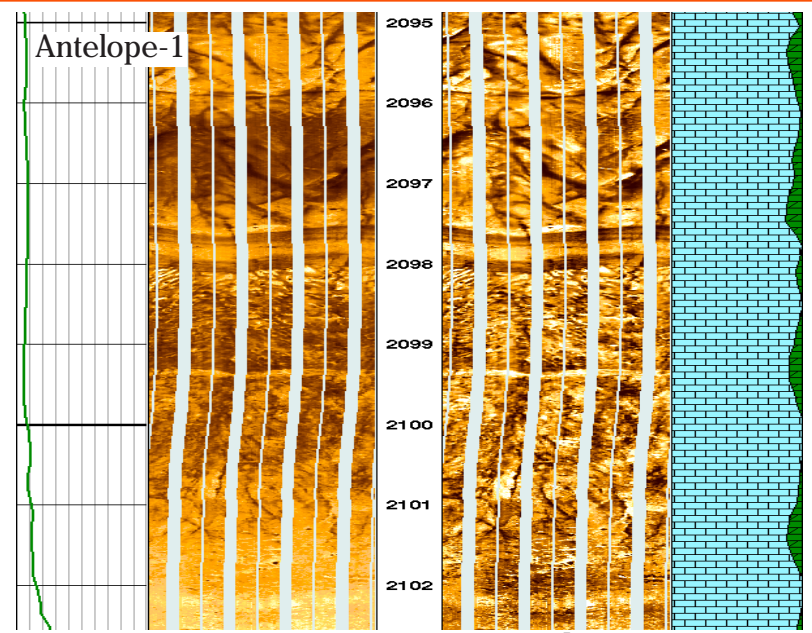

Centimetre- to sequence-scale variations

Observations

1) Electrical conductivity versus resistivity response (indirectly reflecting mineralogical, pore systems and fluid variations)

2) 'Coarse' textures and fabrics (reflecting combined depositional and diagenetic fabrics)

3) 'Clast' \& Vug characterisation, shape, size \& distribution

4) Structures \& their orientations (sedimentary and or others, e.g. fractures)

5) Boundary (bed and/or sequence) location and nature Sequence trends (individual stratal units/beds \& large-scale sequences)

Characterisation \&

Classification of FMI facies

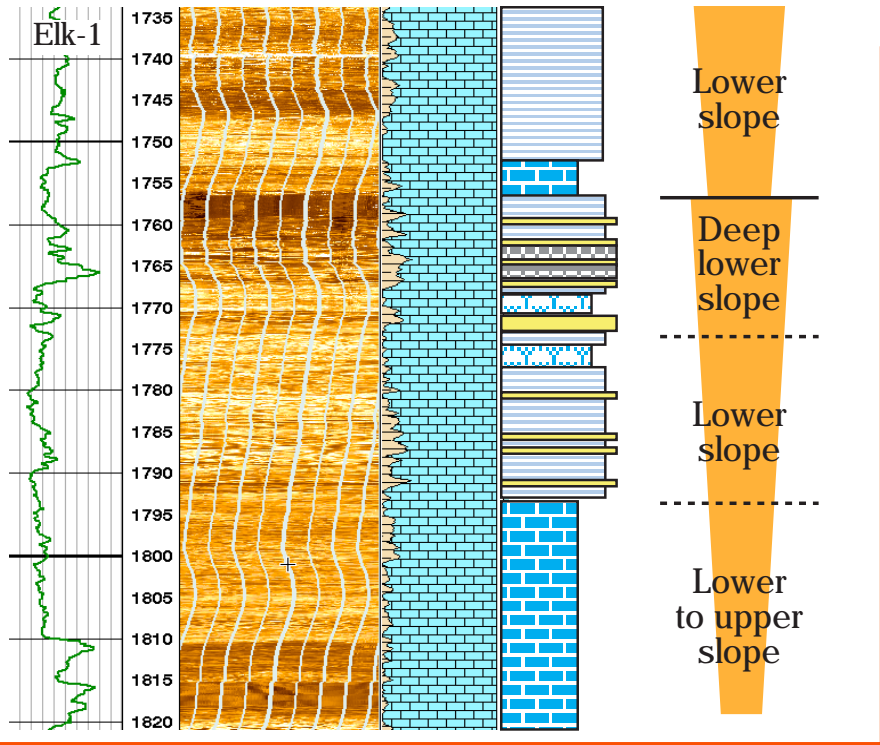

Petrology

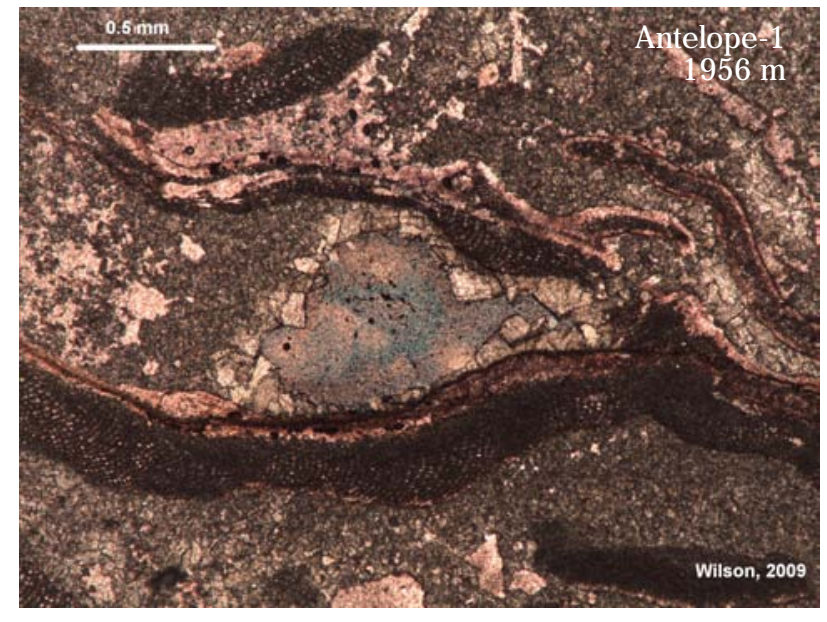

Micro- to centimetre-scale variations

1) Mineralogical, depositional diagenetic $\&$ pore system controls on electrical image (FMI) features and textures.

2) Relationship between microfacies and FMI facies. Some FMI facies may have non-unique origins, but sample data may 'help train' FMI characterisation \& interpretation.

3) Readjustment of sequence boundaries, understanding their nature and better evaluating and interpreting sequence trends.

4) Fill knowledge gaps when one type of data is unavailable, or of poor quality, e.g. when downhole conditions such as borehole rugosity or gas result in reduced quality electrical images, in areas of tool malfunction, or in regions of poor sidewall core recovery (perhaps porosity related).

\section{$\Rightarrow$ \\ Inferences}

Mineralogy (particularly when in combination with other techniques, e.g. $\mathrm{FEQL}$

2) Depositional environments, processes and sequence trends (for environments $\&$ processes inferences may be similar to those possible from petrology, but less certainty due to potential diagenetic overprints affecting $\mathrm{FMI}$ textures).

3) Diagenesis and post-depositional alteration, e.g. commonly used for fracture characterisation/interpretation, but diagenetic features, environments and processes (unless related to very specific fabrics) may prove difficult to recognise and interpret.

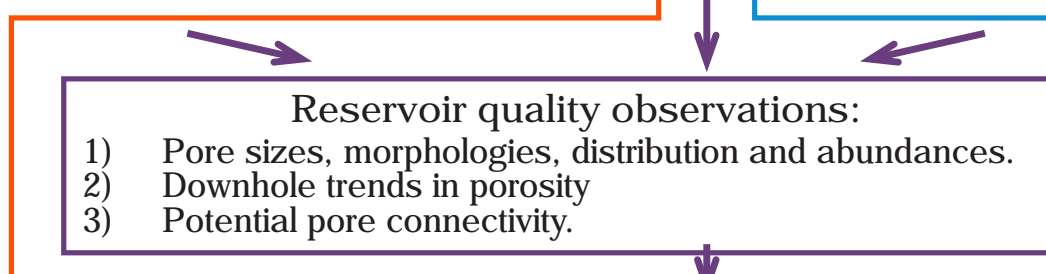

Characterisation \& Classification of Pore systems and in combination with other dataset (e.g. Core Plug Permeametry) Reservoir Rock Types (RRTs) '年

Reservoir quality inferences and predictions:

1) Pore systems development and downhole distribution controls.

2) Combined depositional \& diagenetic impact on reservoir quality.

3) Understanding and predicting RRT distribution in the carbonate system near, and away from, the wells.

4) Providing rigorously researched inputs for reservoir modelling and prediction.
1) Components and theirgrain nents and their grain sizes

2) Bioclast morphologies, fragmentation \& abrasion

3) Primary depositional textures

4) Diagenetic features and their relative timing

5) Mineralogies

6) Pore system types, sizes, morphologies, abundances, distribution \& potential connectivity

Characterisation \& Classification of microfacies

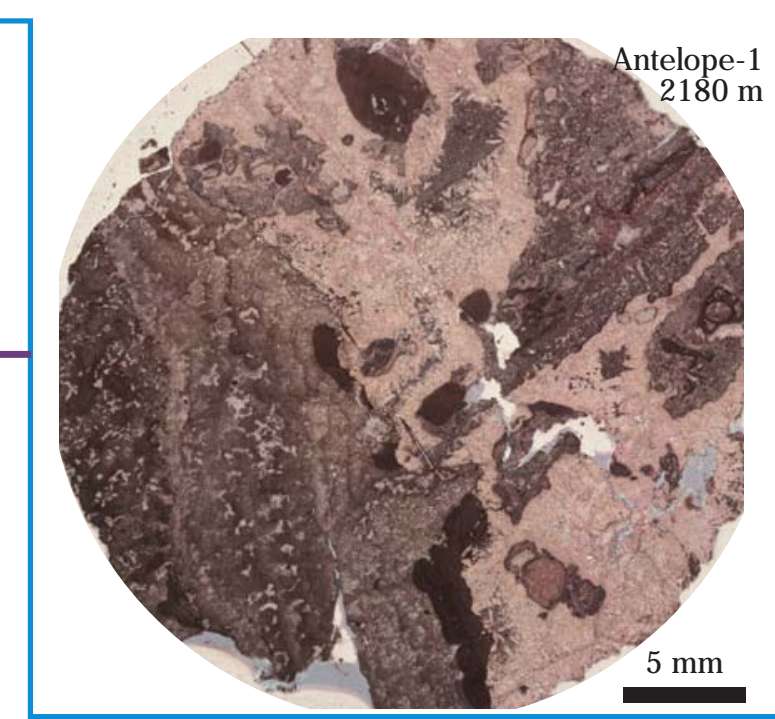

